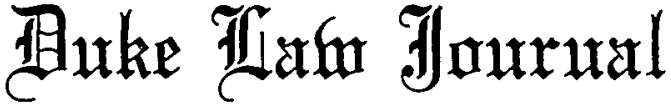

\section{WHEN THE EXCEPTION BECOMES THE RULE: REGULATORY EQUITY AND THE FORMULATION OF ENERGY POLICY THROUGH AN EXCEPTIONS PROCESS}

\author{
Peter H. SCHUCK*
}

Regulatory programs exacerbate the inherent conflict between the values associated with rules and with equity. This conflict is especially acute in programs, like petroleum price and allocation regulation, that regulate complex transactions between diverse firms in a volatile market. Professor Schuck examines one technique for achieving regulatory equity -an exceptions process-in that context. After exploring the different limitations of rules and the relationship between regulatory equity and related concepts, including discretion, judicial equity and agency adjudication, Professor Schuck presents four detailed case studies of the exceptions process in petroleum regulation. He demonstrates that the exceptions process did enhance regulatory equity in that program but also jeopardized important administrative law values.

\section{Contents}

INTRODUCTION

I. Regulation AND Equity .......................... 168

A. The Limits of Rules ....................... 170

1. The Character of Rules.................... 171

\section{Copyright () Peter H. Schuck}

* Professor of Law, Yale Law School. B.A., Cornell University; M.A., J.D., Harvard University. This article is based upon work done by the author as consultant to the Administrative Conference of the United States. The author wishes to acknowledge the invaluable assistance of Jefferey Sellers, candidate for J.D.-D.C.L. degree, Yale Law School, upon whose research the case studies in Part II are largely based, and the useful comments on an earlier draft by Professors Bruce Ackerman, Alfred Aman, Jr., Kenneth Davis, Donald Elliott, Geoffrey Hazard, Jr., Jerry Mashaw, Martin Shapiro, and Peter Strauss, as well as Mr. Jeffrey Lubbers and Mr. William Bush of the Administrative Conference of the United States staff. He also wishes to thank the numerous individuals who agreed to be interviewed in connection with this study. 
a. Limitations of form $\ldots \ldots \ldots \ldots \ldots \ldots \ldots \ldots, 172$

b. Limitations of knowledge .................. 173

c. Limitations of comprehensiveness ............. 175

d. Limitations of articulation.................. 176

2. The Institutional Context of Rules .............. 180

3. The Situational Needs of Rulemakers ............. 181

B. Regulatory Equity and Discretion................. 182

C. Regulatory Equity and Judicial Equity............. 186

1. Institutional Purpose ......................... 186

2. Types of Rules ........................... 187

3. Decision Procedures ........................ 188

4. Organizational Forms and Settings ............. 190

D. Regulatory Equity and Policymaking Through Agency Adjudication.................................. 192

E. Regulatory Equity and the Exceptions Process ......... 199

1. The Problem of Functional Integration ........... 199

2. The Problem of Organizational Integration ....... 199

3. The Problems of Equitable Criteria and Legitimacy................................... 199

4. The Problem of Procedures .................... 199

5. The Problem of Accountability and Control ....... 200

II. The Exceptions Process and Energy Policy ........ 200

A. The Petroleum Industry and Federal Regulation ....... 200

B. The Administrative Structure of the Exceptions

Process ..................................... 209

C. The Exceptions Process in Action: Four Case Studies . 212

1. The Delta-Beacon Program .................. 213

a. The origins of exceptions relief for small refiners ................................ 215

b. Development of the Delta-Beacon standards ... 217

c. Adjustment of Delta relief ................... 220

d. Congressional influences ................... 223

e. Efforts to curtail relief .................... 225

f. Conclusion ............................... 228

2. The Iranian Oil Embargo: The Union and Ashland Cases .............................. 229

a. Union: The exception preempts the rule....... 230

(i). The temporary exceptions proceeding ..... 232

(ii). The choice of decision process ........... 233

(iii). The award of relief to Union............ 235

b. Ashland: The exception precludes the rule .... 236 
3. Pricing Alaska North Slope crude oil-The Ohio Independents: The exception provokes the rule ... 242

4. The Motor Gasoline Crisis of 1979 ............. 247

a. Background: The motor gasoline allocation regulations ............................. 248

b. An overview of the crisis .................. 250

c. OHA in the early stages of the crisis .......... 251

d. The "unusual growth" adjustment ............. 254

e. The floodgates open ...................... 259

f. Conclusion ............................ 262

III. AN Analysis of Doe's Exceptions Process .......... 263

A. Personalizing Bureaucratic Power ................ 264

B. Expansive Conception of the Exceptions Function ...... 266

C. Autonomy ................................... 267

D. Indeterminate Equitable Standards .............. 268

E. Innovative Procedures ........................ 270

1. Notice .................................. 273

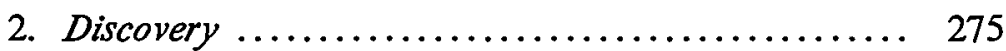

3. Ex Parte Contacts ......................... 276

4. Cross-examination .......................... 277

5. Lawyers' Testimony ...................... 278

6. Interim Relief ............................. 278

7. Mixture of Functions ....................... 280

8. Administrative Review Committee ............... 281

9. Consumer Participation ...................... 281

F. Latent Functions: The Exceptions Process as Safety Valve ........................................ 283

IV. Conclusion ..................................... 289

A. The Problem of Functional Integration ............. 290

B. The Problem of Organizational Integration ........... 291

C. The Problems of Equitable Criteria and Legitimacy.... 293

D. The Problem of Procedures ...................... 294

E. The Problem of Accountability and Control .......... 298

For almost a decade (and as recently as 1981), the Department of Energy (DOE) exceptions process-a process by which a person, firm or entity subject to a valid statutory or administrative rule is relieved from the legal obligation to comply with that rule because of the special features of the situation-was an extraordinarily important regulatory 
device. The DOE's Office of Hearings and Appeals (OHA), ${ }^{1}$ which administered the exceptions process, routinely shifted hundreds of inillions of dollars in cross-subsidies among refiners and made economic life-and-death decisions concerning thousands of business firms and local communities. With the official termination of price and allocation controls on January 21, 1981, the DOE shifted into low gear (some would say neutral) and legislative proposals were introduced to abolish or reorganize the Department. ${ }^{2}$ Despite these developments, the DOE exceptions process is not simply a historical curiosity whose significance vanished with the lines at gas stations. It remams an innovation of singular interest to students of administrative process.

Even if the process were utterly moribund, it would be worth studying in its own right. OHA remains quite active. Its caseload, although well below the levels that prevailed during the motor gasoline crisis of 1979 , continues to be substantial. ${ }^{3}$ Moreover, some of its most controversial cases, involving large policy issues and enorinous sums of noney, are still pending. ${ }^{4}$ Even if a reorganization of the DOE occurs, these pending cases will have to be resolved. It is also quite possible, perhaps even probable, that controls will be reimposed at some future date. So long as the United States economy continues to be vulnerable to shocks resulting from developments in the Middle East, future energy price controls cannot be ruled out. ${ }^{5}$ Indeed, Iran's protracted war with Iraq raises the possibility of convulsive pohtical changes and resulting shortages in international oil inarkets, developments that might lead to a new call for controls.

1. Unless otherwise indicated, subsequent references to the DOE or "the energy agency" may be taken to refer to its predecessor agencies, the Federal Energy Office (FEO) and the Federal Energy Administration (FEA), as well. Unless otherwise indicated, subsequent references to the OHA or "the exceptions office" may be taken to refer to its predecessor offices, the Office of Private Grievance and Redress (OPGR) and the Office of Exceptions and Appeals (OEA), as well.

2. See J. Sellers, Decontrol and Regulatory Legitimacy: The Case of the Entitlements Program (unpublished inanuscript, on file with author).

3. The OHA's authorized staffing level for fiscal 1983 was 119 , compared to 211 in 1980. Its budget for those years was $\$ 5.25$ million and $\$ 5$ million, respectively. Telephone interview with George Breznay, OHA Director, February 16, 1983.

4. The "entitlements clean-up" problein, for example, may involve the disposition of as much as one billion dollars. The OHA has also been given responsibility for effecting billions of dollars in refunds resulting froin past overcharges. See 48 Fed. Reg. 50,624 (Nov. 3, 1983) (proposing end to entitlements program).

5. See, e.g., Congressional Research SERVICE, Western Vulnerability to a DisRupTION OF PERSIAN GULF OIL SUPPLIES: U.S. INTERESTS AND OPTIONS 78-82 (1983); ENERGY FuTURE: Report OF tHe ENERgy Project at the HaRvard Business School $274-76$ (R. Stobaugh \& D. Yerkin eds. 1980); Akins, Prospects of Supply Interruptions from OPEC in the Near Future, in Policies for Coping with OIL-Supply DisRuptions 6-9 (G. Horwich \& E. Mitchell eds. 1982). 
The continuing concerns about regulatory rigidity and the demands for regulatory reform also make research on the exceptions process timely. Changes in administrative law and many proposals for reform increasingly favor policy development through rules and more formal, judicial-type rulemaking procedures. If those trends persist, as appears likely, administrative techniques will be needed that encourage flexible accommodations to diverse and complex conditions within 1 an increasingly rule governed system. A properly structured exceptions process might address that need.

This article exammes the pursuit of regulatory equity through an administrative "exceptions process." Such a process relieves a person, firm, or entity subject to a valid statutory or administrative rule from the legal obligation to comply with the rule. It does so by issuing a formal exception, waiver, or similar form of special relief from the rule's application based upon the special features of the applicant's situation. 6

The article consists of four parts. Part I explores the tension between the conceptions of justice represented by rules and by equity, highlighting the ways in which this tension is expressed in a regulatory context. Part I concludes by posing broad questions about the exceptions process that the study will attempt to address. Part II examines the exceptions process in energy regulation through four case studies of exceptions decisionmaking at the DOE, as administered by the Office of Hearings and Appeals. Each case study illustrates certain themes or tendencies that seem endemic to an exceptions process of this kind. Drawing upon the case studies and other sources, Part III analyzes and evaluates the essential features of the DOE's exceptions process, concluding with a discussion of the exceptions process as a "safety valve." Part IV summarizes the study by offering tentative answers to the questions posed at the end of Part I.

6. Remarkably, the exceptions process has received scant scholarly attention. Apart from studies of the World War II price control program, see, e.g., S. MCMillen, Individual Price Adjustments under OPA: A Study in the DYnamics of Flexible Pricing (1949); V. Thompson, The Regulatory Process In OPA RATIONING $339-43$ (1950), it has been essentially ignored uutil very recently. The first systematic effort to analyze exceptions decisions as a distinctive form of administrative activity appeared in a 1982 article by Professor Alfred Aman. See Aman, Administrative Equity: An Analysis of Exceptions to Administrative Rules, 1982 DuKE L.J. 277 (1982); see also Comment, The Exceptions Process: The Administrative Counterpart to a Court of Equity and the Dangers it Presents to the Rulemaking Process, 30 EMORY L.J. 1135 (1981). A purely descriptive discussion is Cockrell, Federal Regulation of Energy: The Exceptions Process, 7 TRANSP. L.J. 83 (1975). For a general account of economic controls that provides some insights into the problem, see R. KAGAN, Regulatory Justice: IMPLEMENTING A WAGE-PRiCE FreEze (1978). 
It should be emphasized at the outset that this is a study of only one exceptions process and, as the reader shall see, a distinctive one at that. Such a study cannot generate clear implications for other exceptions processes in other agencies with other regulatory tasks, for the truth of any nontrivial generalization about the exceptions process cannot be shown to extend beyond the particular DOE exainple. Such is the awesome power of social science!

Nevertheless, an in-depth study of a particular administrative process can be valuable. It can support at least a qualitative appraisal of the variables important to the performance of that kind of process. It can highliglit the relationships between the various elements of such a process, and the values implicated by those relationships. Even if sucls a study lacks unequivocal normative conclusions, it can still identify problein areas and suggest plausible approaches to reform. In the end, however, the chief arguinent im favor of detailed case studies of administrative process is that they are likely to be superior to the alternatives-conventional wisdom, unconventional intuition, and a methodological rigor and comprehensiveness that the subject matter does not permit.

\section{Regulation AND EQuity}

Federal agency rules that prescribe private conduct are, of course, ubiquitous techniques of social control. Although cominonplace, liowever, they are also relatively novel. As recently as twenty years ago such rules were largely confined to the Internal Revenue Service and the independent regulatory commissions created during the New Deal era. But between 1970 and 1975, Congress established seven major new regulatory agencies and enacted more than 30 grants of broad regulatory authority. ${ }^{7}$ Today, rules liave joined grants-in-aid, taxes, subsidies, jawboning, and aggressive use of the media as instruments by which the federal government attempts to conform private beliavior to declared public policies.

Although the proliferation of sucl rules began to slow in the late 1970 's as regulatory reform efforts took hold, especially in 1981 when the Reagan Admimistration assumed power, ${ }^{8}$ this may prove to be but a pause im a long-term tide of regulatory intervention. The growth of rules, after all, seems to reflect deep-seated changes in American society-far-reaching deinographic and political shifts, a deepening aware-

7. See Lilley \& Miller, The New Social Regulation, 47 PUB. INTEREST 49, 51 (1977).

8. For a discussion of regulatory reform efforts in recent years, see, for example, R. LiTAN \& W. NoRdiaus, REForming FEDERAL REgulation (1983); Harter, Book Review, 67 MINN. L. REV. 1065 (1983). 
ness of ecological complexity, and fundamental economic, moral, and mstitutional transformations. Social goals that rules (and sometimes only rules) seem capable of achieving have become more salient. These goals include eliminating discrimination against vulnerable groups, perfecting markets, strengthening national cohesion and uniformity, redistributing wealth, and inaking policy more "rational" and predictable. ${ }^{9}$

Rules increasingly dominate our collective life. They are the gears in the machinery of modern government. In principle, at least, rules are both instruments of power and brakes upon its exercise. They assist citizens in controlling the activist state because rules specify rights and facilitate remedies for violations. By particularizing citizens' duties, rules also enable the state to influence the conduct of citizens. And rules help both citizens and the state to conduct their affairs on the basis of some common, predictable assumptions concerning the norms and conditions that will prevail.

Rules, then, are necessary conditions of any fully developed, contemporary conception of a just administrative process. But they are not sufficient. Justice also demands that the rigor of rules be tempered by other considerations. So long as values exist that cannot readily be formulated as rules and anomalous cases arise that rules fail to anticipate, rules will constitute an incomplete technology of justice. ${ }^{10}$ As the social domain in which rules govern expands, the occasions of such rulebased injustice will multiply, perhaps exponentially. In such situations, the infusion of equity imto the regulatory process-what I shall refer to as "regulatory equity" 11 - will becoine an ever more vital component of the admimistrative process.

9. See, e.g., Schuck, The Politics of Regulation, 90 YALE L.J. 702, 724-25 (1981). The strong einphasis upon rules and a legalistic approach to regulation, as distinguished from more flexible, cooperative methods, may be a distinctively American phenomenon. For some imteresting international coinparisons, see, for example, S. Kelman, Regulating America, Regulating Sweden: A Comparative Study of Occupational Safety and Health Policy (1981); Vogel, Cooperative Regulation: Environmental Protection in Great Britain, 72 PUB. INTEREST 88 (1983).

10. Not all rules are equally problematic. The form and context of a rule, for example, affect the need for modulation in the interests of justice. Thus, in constitutional law, torts, and contracts, rules increasingly tend to be open-textured, indeterminate, and readily tailored to individual fact situations. In contrast, rules administered by regulatory agencies tend to be more determinate and specific. Cf. Kennedy, Form and Substance in Private Law Adjudication, 89 HARv. L. Rev. 1685, 1686-89 (1976)(distinguishing between "rules," which provide for certainty of results, and "standards," which, by emphasizing underlying policy objectives, allow a more precise result im some cases). Even in regulatory law, however, rules vary considerably along these and other formal dimensions. See Diver, The Optimal Precision of Administrative Rules, 93 YALE L.J. 65 (1983).

11. Professor Alfred Aman, describing essentially the same phenomenon, has used the term "administrative equity." See Aman, supra note 6, at 280. Although the terms are functionally interchangeable because any administrative apparatus that applies rules must somehow deal with the claims of equity, I prefer to emphasize the regulatory dimension. This reflects my conviction that this problein is more acute and complex when the body of law that is being developed has 
A. The Limits of Rules.

That rules cannot fully achieve justice is an ancient theme in legal theory. Aristotle distinguished between "legal" justice, based upon general rules, and "equity," which corrects what is inerely legally just. ${ }^{12}$ That distinction has been reflected in many important institutional and doctrinal developments. Examples include the equitable jurisdiction of courts; the evolution of many rigid common law rules into more flexible standards, such as "reasonableness," in which equity is "built-in"; 13 and the open-ended, indeterminate standards contained in much modern legislation.

Regimes of rules and of equity are based upon fundamentally different conceptions of justice; each conception, taken alone, is radically incomplete. The regime of rules is general and prescriptive. It requires at a minimuin that a decisionmaker accurately apply general, clearly articulated norms to fairly established facts. In contrast, the regime of equity is specific and ad hoc. It requires that any such norns be subordinated to an overriding standard of contextual fairness-that is, fairness to individuals in light of their particularized situations. Rules respond to the gravitational pulls of backward-looking precedent, forward-looking policy, or outward-looking analogies and notions of legal equality. Equity resonates to the inward-looking concerns of the iminediate, to the riveting force of the particular, the situational. Those who value rules emphasize the need for commonality, regularity, continuity, and order. Those who esteem equity stress the importance of individuahty (we are unique), spontaneity (we are not bound by the past), responsiveness (our needs change), and freedom (our course is not predetermined). Whereas rules exalt formal categories, equity is profoundly suspicious of abstraction and seeks to free diversity from the delusive discipline of order. Equity speaks not to the typical caseindeed, it unay even deny that such a thing exists-but rather to the exotic, the unexpected, the exigent. Its distinctive tecliniques are neither coinprehensive vision, synoptic analysis, nor disembodied principle, but sound judgnient, contextual analysis, and an intuitive "feel" for what is fair under the circumstances.

crucial competitive market implications, and especially when the agency actually supervises an industry, than it is when the administrative context lacks one or both of these features, as in the Social Security program.

12. ARistotle, Nichomachean Ethics, V.10.1137-38 (W.D. Ross trans. 1915).

13. See, e.g., Kennedy, supra note 10, at 1685, 1686-89. 
Rules glorify precisely those technocratic values-predictability, stability, uniformity, and control-about which equity is most skeptical; they systematically overlook or override certain particularities of time, place, and context. Our sense of justice, however, often demands that these particularities receive greater recognition and weight than rules ordinarily accord them. We can readily imagine sets of facts that come well within a rule's terms yet seem to call for a different disposition. When such an instance occurs, justice seems to call for suspending the rule in that case, without necessarily calling its general validity into question. Equity, too, entails certain risks, but they are the risks of uncertainty, irrationality, favoritism, diversity, and incoherence-precisely those that an increasingly rationalistic, centralized, control-oriented society wishes to minimize. The tension in our law between rule and equity, then, can never be eliminated. It will persist, as Thurman Arnold noted, "[s]o long as inen require a moral and logical ideal to satisfy their impulses toward mercy and common sense."14 The quest for regulatory equity is a searcls for an appropriate means to harmonize these eternally conflicting values.

Any complex system of rules that aspires to justice must make some provision for regulatory equity. Although classes of cases always exist in which rules create injustice, this does not explain what it is about a case that places it within those classes. It fails to reveal which characteristics deinand that the rule be suspended rather than applied, and which reasons or motives make an appeal to equity seein appropriate. The following discussion attempts to provide that explanation.

The limits of rules define the boundaries of regulatory equity. Broadly speaking, three general categories of conditions or reasons may mark those limits. The need for regulatory equity may derive from certain features of the rule itself, from the institutional context in which the rule is developed and applied, and from situational needs of the decisionmaker that may have nothing to do with the rule's own features or context.

1. The Character of Rules. Like any structure for deciding particular cases, a regime of rules necessarily dispenses imperfect justiceimperfect in the sense that decisions derived from it inust reflect whatever limitations rules possess qua rules. This discussion addresses four potential limiting features: form, knowledge, coinprehensiveness, and articulation. Every rule has at least some limitations. These may often be reduced (at some cost) but can never be wholly eliminated, for

14. T. ARnold, The Symbols of Government 62 (1935). 
they inhere either in the nature of rules or in the complexity of reality. Insofar as these limitations remam, perfect justice solely through a regime of rules is unattainable.

(a) Limitations of form. Three formal attributes of a rule determine the extent to which it can achieve its purposes without equity's assistance: its generality (the number of cases to which it is meant to apply), its transparency (the degree to which it evokes uniform interpretations in different minds), ${ }^{15}$ and the nunber of unweighted factors that it makes relevant to its application. These attributes are empirically as well as analytically distinct. For example, a very general rule may have ambiguous language and prescribe multiple unweighted factors. As the twenty-sixth amendment demonstrates, ${ }^{16}$ however, a rule need not have either of these attributes.

The ancients recognized that rules' formal imperfections can cause imjustice. Aristotle maintamed, for example, that the law could not achieve true justice in part because it "takes the usual case." 17 But the relationship between the form of rules and the content of justice is more intricate than this categorical statement suggests. Judges seldom take "the usual case," preferring instead to formulate the narrowest rule that can connect the facts of a dispute to some source of decisional legitimacy, such as a precedent, statute, constitution, or "natural right:" The level of generahty at which legislators and regulators frame rules is often a matter of conscious policy choice; it is influenced by the signiflcance they accord to predictability, equal treatment, flexibility, mcremental policy developinent, and other values in a particular context. ${ }^{18}$

Transparency and the number of unweighted decision factors also affect a rule's efficacy. A rule may be so opaque, or may enumerate so many unweighted factors, that it cannot generate reasonably predictable outcomes. As Aristotle wrote, "when the thing is indefinite the rule also is indefinite." 19 A rule that "undesirable behavior" is tortious, for example, would afford no hint as to what conduct might be actionable, even if one could predict with confidence how cases at the extremes (e.g., murder, marriage) would be decided. Such a provision fails to perform even minimally those functions-bounding administrative dis-

15. For a discussion of this attribute, see Diver, supra note 10 , at 67 .

16. U.S. CoNST. amend. XXVI, $\& 1$ ("The right of citizens . . . who are eighteen years of age or older, to vote shall not be denied . . . on account of age.").

17. ARISTOTLE, supra note 12, at V.10.1137a.

18. For a discussion of many of these factors, see Diver, supra note 10, at 67, and ADMINIStrative Conference of the United States, Statement on Guidelines for Choosino the Appropriate Level of Agency Policy Articulation, 1 CFR § 310.9 (1984).

19. ARISTOTLE, supra note 12, at V.10.1137b. 
cretion, predictability, encouraging equal treatınent, facilitating legislative and judicial review-that constitute rules' distinctive contribution to a just legal regime.

A rule that is too transparent may also be unable to attain its purpose. Consider the following example: "If a Ford strikes a Buick on July 16,1985 , the driver of the Ford shall pay $\$ 100$ to the driver of the Buick." This rule is stunningly determinate, indeed so inuch so that it may well deny due process or equal protection by practically assuring that virtually identical driving behavior will have very different legal consequences, depending upon happenstance. ${ }^{20}$

Any given rule, then, expresses an inescapable tension between the virtues and vices of each of its formal elements. A more general rule controls more cases but only by subjecting more diverse phenomena to its homogenizing prescriptions. A vaguer, more ambiguous rule permits greater flexibility in adapting to new or unanticipated conditions but only by reducing the predictability and uniformity of outcoines. A multifactored rule, especially one that fails to weight the factors, enriches the administrator's ability to discriminate among complex phenomena but diminishes the rulemaker's (or reviewing court's) control over particular decisions. Regulators can only transcend these limitations by looking beyond the regime of rules to the ethos of equity.

(b) Limitations of knowledge. We are extraordinarily ignorant of the intricate web of cause, consequence, and circuinstance im which our intentions and actions are shaped and executed. But however little we know of the world as it is, we know even less of the world that will be. A regime of rules, of course, is directed to the future. To Aristotle, equity ineant deciding cases as the "legislator himself would have said had he been present, and would have put into his law if he had known."21 In this view, when cases arise that the rule did not envision and to which it cannot justly be applied, equity must effect what the rulemaker's want of prescience makes necessary; it inust suspend or reformulate the rule (Aristotle does not indicate which) to achieve a just outcome in the unforeseen case.

This notion of the relationship between imperfect knowledge and equity seems quite incomplete, at least in the regulatory context. Imagine a perfectly prescient ruleinaker. She fully coinprehends the implications of all rules that she might issue, foresees all changes that might

20. The transparency of certain rules renders them constitutionally invalid for somewhat different reasons. See Woodson v. North Carolina, 428 U.S. 280, 302-05 (1976)(mandatory capital punishment statute).

21. ARISTOTLE, supra note 12 , at V.10.1137b. 
occur, and anticipates all cases that may arise in the future. Is it clear, as Aristotle implies, that this clairvoyant seer would formulate a rule resolving in advance all cases yet to come? And if she would, would this achieve perfect prescriptive justice, rendering equity superfluous? The answer to botl questions, it would seem, is no. She might believe, for example, that by framing a rule today that will anticipate and correctly decide tomorrow's case, she would incur unacceptable political costs in attempting to persuade others to accept that rule. She might therefore prefer to proceed incrementally, issuing a more limited but noncontroversial rule now and deferring the resolution of future cases to a later day. If she also faced high information costs in formulating a rule capable of fully anticipating the future, she might find an incremental strategy even more attractive.

Aristotle also seems to have been wholly concerned with rules formulated by ruleinakers who not only are ignorant of the future but also proceed as if they were unaware of their ignorance. Yet some rulemakers are aware of their ignorance and guard against it in fashioning rules. Both kinds of rules demonstrate the need for regulatory equity, but each implies somewhat different responses to that need. Unanticipated ignorance, of course, is commonplace; we seldom know precisely what we don't know. Attempting to resolve unforeseen cases through rules never designed to apply to them will lead to harsh, absurd outcomes unless equity can palliate them. Of course, rulemakers who are unaware of their own ignorance may not perceive the contingent need for regulatory equity, much less provide an institutional means to achieve it. They may still pursue equity, but will not ensure that certain mechanisins for attaiming it are available.

Ignorance of the future can often be anticipated and its most deleterious effects blunted. Even if regulators cannot map the future in detail, they can sometimes discern the broad contours of contingency that must be faced and design rules to conform to that dimly perceived topography. Suppose, for exainple, that an official inust regulate a rapidly evolving technology, such as telecommunications. She knows or strongly suspects that the activity will present a very different face in twenty years than it does today. She anticipates that technology, industry structure, market conditions, and consumer preferences will change significantly but she cannot predict with confidence the precise nature of those changes. Unwilling to rely upon highly speculative forecasts, but aware of the uncertainty problen, she lias several options. She nay decide to proceed incrementally, eschewing rules in favor of policymaking through case-by-case adjudication. She may instead promulgate rules containing vague language or multiple, unweighted decision 
criteria, thereby preserving flexibility for the volatile future. Alternatively, she may devise a more determinate rule to govern what she thinks the future will bring but create an auxiliary administrative process that can provide equitable relief from the rule whenever appropriate. Each of these approaches recognizes the substantial claims that equity may assert against an uncertain future.

(c) Limitations of comprehensiveness. A rule does not always govern autonomously, even within its well-defined boundaries. Dominion over its subjects may be hotly contested. Professor Dworkin illuminates this point by distinguishing between rules, policies, and principles. ${ }^{22}$ Altlough developed for an altogether different purpose, Dworkin's distinction nevertheless suggests several ways in which noncomprehehsive rules may demand regulatory equity. For Dworkin, a rule is a standard that is absolute, "applicable in an all-or-nothing fashion",23 it prescribes a particular result if the particular facts that it stipulates are present. A principle, however, is a standard that asserts a requirement of morality; it does not prescribe a particular outcome but merely "states a reason that argues in one direction." 24 Its reach depends upon its weight or importance. In contrast, eacl rule has equal weight, at least for purposes of resolving conflicts between them. ${ }^{25} \mathrm{Fi}$ nally, a "policy" is a standard that sets a social goal to be pursued. ${ }^{26}$

Rules, principles, and policies often compete to imfluence or control the outcome of administrative decisions. First, the slieer volume of rules promulgated and administered by an agency increases the risk that any rule that seems to cover a particular set of facts will encounter another rule with its own plausible claim of coverage. The agency, of course, can resolve sucll a conflict, but only on the basis of some other ground of decision. Second, policy is really an aunalgam of conflicting policies (in Dworkin's sense of the term) that reflect its multiple statutory objectives, its diffuse pohtical constituencies, and the programmatic and administrative reahties within which it nust work. A rule, then, may not only contradict other rules but also conflict with policies not fully embodied in rules, policies as firmly within the agency's charge as those that underlie that rule. Here, too, only some overriding criterion-whether a rule, principle or policy-can ultimately resolve sucl conflicts. Finally, an agency's rules are part of a continuing, in-

\footnotetext{
22. R. DWorkin, TAkING Rights SERIOUSLy 24-78 (1977).

23. Id. at 24.

24. Id. at 26.

25. Id. at $23-26,73-78$.

26. Id. at 22 .
} 
tense conversation with the legislature, courts, and society at large concerning the scope and meaning of the agency's purposes and methods. That conversation leads to appropriate accommodation of rules and equity and clarifies the values that each represents. ${ }^{27}$

Threats to the comprehensiveness and autonomy of an agency's rules, consequently, come from several quarters-from conflicts between rules, from policies and principles that exemplify other values, and from other imstitutions. These sources of tension reflect moral, administrative, and political imperatives to which an agency must somehow respond. For example, when the Occupational Safety and Healtl Administration is challenged to justify an occupational safety standard that imposes heavy costs upon regulated firms, it cannot simply point to its broad statutory authority to develop rules that minimize risks to workers. Even before an agency promulgates a statutorily authorized rule, it must take account of competing policies (e.g., the objective of mamtaining a viable industrial sector) and competmg principles (e.g., a worker's healtll is not protected if her employer is forced out of business)..$^{28}$ Equity is one integrating technique.

(d) Limitations of articulation. In our legal culture, the legitimacy of a rule-and perhaps its validity as well-ordinarily requires that the reasons adduced in its support be justified in terms of some preexistimg, appropriate premise of decision, some rule or principle whose generality, by transcending the particular case, avoids the risks of arbitrariness inherent in ad hoc decisionnnaking. It is not sufficient that the decisionmaker either flips a fair $\operatorname{coin}^{29}$ or admires one of the parties.

The norm that legal decisions should be reduced to writing ${ }^{30}$ is designed in part to secure and reinforce this rational element of legiti-

27. Duncan Kennedy, using different but somewhat analogous categories, suggests that the introduction of equity (what he calls "standards") into a rule-dominated system may be a way of seeining to humanize an unjust system of law or, alternatively, a way of weakening the hold of such a system, "keeping alive resistance in spite of the capture of the substantive order by the eneiny." Kennedy, supra note 10 , at 1777.

28. See, e.g., Industrial Union Dep't, AFL-CIO v. Anerican Petroleum Inst., 448 U.S. 607, 646-51 (1980).

29. See N.Y. Times, May 29, 1982, at 25 , col. 6.

30. See, e.g., F. Coffin, THE WAYS OF A JUdGe 57-58 (1980).

There are many situations in which an agency could rationalize particular regulatory outcomes in terms of a general rule, but does not. Numerous routine, noncontroversial decisions, such as contract or grant awards, are largely discretionary. Although the lack of standards in such cases does not wholly elininate the value of giving reasons, it does obviate most of its advantages. This is because giving reasons, if more than a desultory gesture, consumes scarce time and personnel; for some regulatory decisions, these process costs would exceed the value of such benefits as reducing errors, increasing acceptance of adverse decisions, and facilitating review of decisions. 
macy. The obligation to render a written decision subjects one to an intellectual discipline, a public process of justification, in which one must struggle to link rules, principles, evidence, inference, and logic into a chain of reasoning that can command general respect. But although the articulation of reasons grounded in general rules is a noble aspiration of our legal systeın, many regulatory decisions fail to fulfill it. ${ }^{31}$ The norm of reason-giving is not nearly as well-established for regulators as for judges. Agencies sometimes provide reasons when they are not legally obligated to do so, but their articulation is often cursory, conclusory, and of little use to one seeking to evaluate a decision's substantive rationality.

Although the law often permits decisionmakers to refrain from providing reasons, the nature of certain decisions may actually preclude thein from doing so. Several situations illustrate this predicament. First, an administrator may apply a clear and indeterminate rule and reach a decision that seeins justified, though not required, and yet be unable to elucidate precisely how she reasoned from the one to the other. Either because a governing norm requires it or because complex policy considerations demand it, the administrator may feel obliged to take many unweighted factors into account. Here, the reasons that support the ultimate decision would include at least an explanation of each factor, an assessment of the decision's empirical relationship to the real world, and a description of the implicit weighting scheme by which the agency integrated the factors into a decision. In principle, the decisionmaker could reconstruct her mental operations, make them explicit, and place them on public view so that the elements of her decision can be scrutinized and evaluated. In practice, however, she

31. The Administrative Procedure Act (APA) requires an agency to give reasons only in connection with formal rulemakings or formal adjudications, 5 U.S.C. $\$ \S 556-557$ (1982), which account for relatively few agency decisions. In the large, increasingly important category of informal rulemaking, the final rule need only "incorporate . . . a concise general statement of [its] basis and purpose." 5 U.S.C. $\$ 553$ (c) (1982). That statement, of course, must be sufficiently specific and complete to enable effective judicial review of the decision. Some appellate courts have interpreted this requirement to mean a fairly detailed justification of rules. See, e.g., Kennecott Copper Corp. v. EPA, 462 F.2d 846, 850 (D.C. Cir. 1972). See generally Pedersen, Formal Records and Informal Rulemaking, 85 YALE L.J. 38 (1975). Still, the requirement was not intended to duplicate the rigor of judicial reason-giving and reviewing courts have tended to demand somewhat less in the way of agency articulation. See, e.g., Kenworth Trucks v. NLRB, 580 F.2d 55, 58-59 (3d Cir. 1978). But see Motor Vehicle Mfrs. Ass'n v. State Farm Mut. Auto. Ins. Co., 103 S. Ct. 2856, 2866 (1983). For informal adjudications, which comprise the vast inajority of agency decisions, the APA imposes no procedural requirements at all, much less an obligation to articulate reasons. Many cominentators have deplored this lacuna. See S. BREYeR \& R. STEwART, Administrative LaW and Regulatory Policy 524-30 (I979). 
probably could not identify, much less articulate, all of those elements, either to herself or to others. ${ }^{32}$

In the situations described above decisionmakers can in principle base their decisions on identifiable general rules. In other situations, however, decisionmakers cannot devise a general rule from which to derive and rationalize decisions. To put the point another way, there are decisions the justice or correctness of which cannot intelhibly be measured by their consistency with a rule. Professionals frequently make decisions of this kind. Physicians, for example, must sometimes diagnose illness or prescribe therapies without being able to anchor those decisions in a general rule or principle, yet they feel confident that they are correct and that professional colleagues would do likewise. Experienced social workers or lawyers sometimes encounter problems that do not fit readily within conventional categories, yet they will often devise particular solutions that seem "just," "appropriate," or snnply "feel right."

Decisions of this kind can arise for two reasons. First, certain decisions require a high degree of specialized judgment and are virtually immune from any nonprocedural, objectively verifiable criticism. The central ingredient of such decisions-an idiosyncratic, mtuitive, essentially subjective apprehension of reahty-is maccessible, indeed antithetical, to generalization. Second, certain decisions are designed to be wholly discretionary. They do not necessarily require ineffable or intuitive judgment; indeed, it may be perfectly possible to specify the controlling factors in the forn of a general rule. Wholly discretionary decisions perforin a social function they could not perform if they were systematized and regularized by rules. They are auxiliary components of a complex administrative system whose routine activities-here, the application of rules to particular facts-generate pressures that threaten the system's continuing viability or integrity. These pressures may include dissatisfaction with the rule's policy, perceived inequities in the rule's initial apphication, changes in circumstances, and the like. When such pressures exceed the level that the system is designed to tolerate,

32. Reasoning from complex, multifactor premises to a decision is probably more cybernetic and heuristic than formally rational and synoptic. See generally J. STEINBruner, THE CYBERNetic Theory of Decision: New Dimensions of Political Analysis (1974). If one could specify the factors of decision, how they relate to one another and to the real world, the contingencies that bring them into play, and the weight to be applied to each, then one could actually devise a computer program that would yield a decision accurately reflecting those decision ingredients. But to infer or "post-dict" from a complex decision to the ingredients that produced it is a very different inatter. In such cases, the reasons decisionmakers articulate cannot fully or accurately reveal the grounds for their decision. Our brains can perform far more complex tasks of integration than we are capable of recapturing and verbalizing. As Polanyi put it, "we can know more than we can tell." See M. Polanyi, The Tacit Dimension 4 (1966); see also D. Schon, TiIe Reflective Practitioner viii (1983). 
the wholly discretionary decision comes into play. Like a safety valve in a mechanical systein, discretion relieves pressure by assuming soine of the systein's functions and altering how it performs others.

The pardoning power, deployed through executive clemency, dramatically exemplifies this safety valve function. This power is plenary, exercised without any governing or even constraining standards. ${ }^{33}$ Pardoning decisions are not "intuitive" as that tern is generally used; their standardlessness is not inherent $i \mathrm{i}$ the kinds of judgments demanded by pardoning decisions. Such decisions could, both in principle and in practice, be regulated by rules. Criminal sentencing and parole decisions, for example, which do not demand fundamentally different kinds of judgments than pardoning decisions, are soinetimes constrained by substantive rules. ${ }^{34}$ Arguably, rules would make executive clemency more predictable, accurate, visible, and rational tlian its present, wholly discretionary character permits.

But structuring the pardoning power tlirough rules would impair its ability to give justice individual form and to soften the remaining rigidities of an already discretionary criminal process. To do so would not merely alter outcoines (for better or for worse) but would fundamentally change the nature of the pardon decision, undermining its very raison d'etre. Executive clemency, after all, is not designed to enhance horizontal equity among prisoners or to yield predictable decisions. It seeks extraordinary justice in particular cases, not ordinary justice in the general run of cases. Far froin generatimg expectations in prisoners, executive clemency decisions are socially valued precisely because they deny the legitimacy of sucl expectations. ${ }^{35}$ An exercise of cleinency is an expression of inercy, an act of grace, an acknowledgement of the insufficiency of rules. It cannot be transformed into its opposite without abandoning its distinctive claim to advance a radically different conception of justice.

Wholly discretionary decisions obviously risk favoritism, arbitrariness, and abuse, conditions inimical to the rule of law. Moreover, their standardlessness renders review by superior authority very difficult. Therefore, wholly discretionary decisions are usually confined to situa-

33. See United States v. Klein, 80 U.S. (13 Wall.) 128, 140-42 (1871). But see Note, A Matter of Life and Death: Due Process Protection in Capital Clemency Proceedings, 90 YALE L.J. 889, 90511 (1981).

34. See Vorenberg, Decent Restraint of Prosecutorial Power, 94 HARv. L. Rev. 1521, 1562-72 (1981).

35. For a discussion of a related issue, see Connecticut Bd. of Pardons v. Dumschat, 452 U.S. $458,465-67$ (1980)(fact that a state board of pardons has granted approximately three-quarters of the applications for commutation of life seutences does not create an entitlement so as to require the Board to justify its denial of such an application). 
tions in which those risks are mininal; they affect persons whose status is already so degraded that an unfavorable decision will leave them hittle or no worse off than if no such decision process had been available at all. ${ }^{36}$ This "what do I have to lose?" condition is notably absent in conventional regulatory schemes, where predictability and the protection of property rights and expectations are especially important values. $^{37}$

2. The Institutional Context of Rules. A regime of rules is embedded in a set of institutional arrangements through which general prescriptions are developed, promulgated, applied, evaluated, and perhaps modified. The ability of such a regime to achieve justice without recourse to equity depends upon the institutions charged with performing these rule-sustaining functions. Because certain institutions are especially hospitable to rule-based justice and others to equity, the legal system can affect how equitable considerations shape a rule's application by entrusting it to the ministrations of one kind of institution rather than another.

The organization, ideology and operating procedures of cominon law courts, especially those engaged in private adjudication, encourage judges to be more preoccupied with the interests of particular litigants than with those of the larger society. Regulatory agencies, however, tend to weigh policy and programmatic considerations inore heavily, even when they adjudicate. ${ }^{38}$ As Part II will demonstrate, this distinction reflects differences in the institutional purposes, types of rules, decision procedures, and organizational forms and settings of courts and agencies.

Legislatures present a somewhat inore complex pattern. Their most characteristic output, the public bill, ordinarily takes the fornt of a general rule. This is not surprising. Generality not only miminizes the risk and appearance of legislative favoritism but also captures substantial "economies of scale" in legislative production. Legislatures, how-

36. The power of a jury to acquit the accused in a criminal case is another example. See $\mathrm{M}$. KaDish \& S. KaDish, Discretion to Disobey: A STUDy OF LAWFUl DEPARTURES FRoM LEGAL RULES 47-50 (1973).

37. In conventional regulatory schemes, treatimg A "differently" than B may create highly visible competitive distortions and disadvantages, not only creating unfairness but undermining the agency's programmatic goals. But even there, what is being regulated may be so complex and variable that rules alone cannot assure desired outcomes. In such cases, substantially, if not wholly, discretionary decisions may be necessary.

38. Cf. G. Calabresi \& P. Bobbit, TRAGic Cholces, 71-72 (1978)("The reasons for using adopted aresponsible agencies to make tragic choices may be traced . . . to the desire to make the grounds for decision less direct and perhaps even less obvious, while at the same time trying to make sure that the decisions are based on broadly held social values."). 
ever, have also established specialized organs to dispense particularistic justice. Private bills, which typically prescribe results intended for only one or a small number of beneficiaries, are ordinarily processed under unique procedures. ${ }^{39}$ Public bills, of course, are soinetimes drafted to achieve decidedly particularistic results-for example, so called "Christmas tree" tax amendments designed to benefit one or relatively few coinpamies. Even there, however, special procedures are needed to minimize abuse. ${ }^{40}$

The relationship between different conceptions of justice and the institutions created to implement them is not simply a matter for institutional designers in the legislative and executive branches. Courts also influence this relationship, most notably by elaborating a common law of administrative process designed to render agency decisionmaking inore regularized, generalized, visible, and susceptible to judicial scrutiny and control. 41 To facilitate judicial review, for example, courts have encouraged agencies to use rules. This, in turn, increases the need for regulatory equity to supplement and refine those rules. On the other hand, when adjudicating in a common law mode, courts tend to avoid rule-like decisions that might constrain their future flexibility.

3. The Situational Needs of Rulemakers. Both the inherent imperfections of rules and the particular mstitutional settings in which they are developed and applied nnay create lacunae in the structure of regulatory justice that only equity can fill. But not all deinands for equity are so systematic. Some are ad hoc, reflecting the incentives that confront particular ruleinakers in particular circumstances. Two of these circumstances are particularly important: the need to win political support for agency decisions and the need to process a large volume of cases with scarce administrative resources.

An official may wish to issue or enforce a rule that is politically controversial. In order to mobilize sufficient support for the rule, she may need to satisfy potential opponents either that it will not apply to them or, in the event that it does, that they will not be adversely affected by it. For a number of reasons, the rule may need to be quite

39. See P. Schuck, The Judiciary Committees 242-65 (1975).

40. See, e.g., W.H. Brown, Constitution, Jefrerson's Manual and Rules of the House of Representatives, H.R. Doc. No. 398, 96th Cong., 2d Sess. 492-508 (1981); J. SAPP, Senate Manual, S. Doc. No. 1, 96th Cong., 1st Sess. 13-14 (1979).

41. This judicial ambition persists even in the face of rather clear congressional intent to preclude judicial review. See, e.g., Johnson v. Robison, 415 U.S. 361, $366-74$ (1974). Even when the courts have acquiesced in a statutory preclusion of review, they have stressed the agency's unique institutional competence to nake the equitable, situation-specific decisions that the legislature desires. See, e.g., Hahn v. Gottlieb, 430 F.2d 1243, 1249-51 (1st Cir. 1970). 
general in form; hence, it inay be impossible to allay the concern of potential opponents. In such situations, the official may couple the rule with soine equitable process by which those adversely affected can hope to obtain relief froin its burdens. ${ }^{42}$ Moreover, by assuring that a rule will not preclude consideration of special factors that may arise, such a process may also make the rule easier to defend in court. ${ }^{43}$

Regulatory equity can also be a tactical response to the reality of scarce administrative resources. The time, personnel, and budget required to enforce broad rules on a case-by-case basis may be extremely costly and the resulting benefits meager. Nonetheless, officials may want the rule on the books where it can encourage some voluntary compliance and project a coherent regulatory posture. Under those circumstances, they may be inclined to retain the rule but grant relief to classes of the regulated, such as small firms, if that will conserve administrative resources without undermining the actual or perceived integrity and viability of the regulatory program as a whole..$^{44}$

\section{B. Regulatory Equity and Discretion.}

There is an intimate relationship between regulatory equity, $m$ the sense in which that concept is used here, and discretion. Discretion, according to its chief expositor, Professor Kenneth Davis, exists "whenever the effective limits on [an official's] power leave him free to make a choice among possible courses of action or maction." 45 An equitable

42. The existence of such a process can mollify not only those to whom the rule may apply but also their political patrons in Congress and the executive branch. See infra notes $422-23$ and accompanymg text.

43. Many court decisions during the 1970 's, for example, invalidated overbroad administrative rules that created "irrebuttable presumptions." For a general discussion of these cases, see $\mathrm{J}$. Mashaw, Due Process and ITs Discontents (forthcoming); see also FCC v. WNCN Listeners Guild, 450 U.S. 582, 610 n.12 (1981) (Marshall, J., dissenting), and cases there cited; Diver, Policymaking Paradigms in Administrative Law, 95 HARv. L. REV. 393, 405 n.62 (1981), and cases there cited.

44. For example, the Nuclear Regulatory Commission exempts from its program for licensing special nuclear materials those hicensees that have less than specified quantities of such material. Domestic Licensing of Special Nuclear Materials, 10 C.F.R. $\$ \S 71.7-.10$ (1982).

In his study of the wartime Office of Price Admmistration, Victor Thompson found that exceptions appealed to harried administrators for other reasons as well. First, adininistrators sometimes wished to grant an applicant rehef but feared that doing so by rule would open the fioodgates. Because exceptions had relatively low public visibility, they hoped to grant the most pressing apphications without encouraging others to claim similar treatment. Exceptions also avoided the need to issue narrow-gauged rules that might seem arbitrary and politically motivated. OPA regulators, Thompson found, wished to keep the rules general and "pure." They had an "abhorrence of a rule governing a very small group, especially a named group, in the regulations"; they had fewer qualms, however, if the same group was named in an exception order. V. Thompson, The Regulatory Process in OPA Rationing 342 (1950).

45. K. Davis, Discretionary Justice: A Preliminary Inquiry 4 (1969). 
standard, by its very nature, creates some discretion in the official who applies it; a number of different outcomes will be consistent with that standard. Discretion, therefore, affords decisionmakers leeway within which they can give equitable considerations some weight when they apply a rule.

But regulatory equity and discretion are by no means identical concepts. Regulatory equity is an objective or goal of the legal system, while discretion is a legal form or technique, a means to that end. Discretion is necessary to achieve regulatory equity but it is not an end in itself. The relationship between discretion and regulatory equity is revealed in the different techniques through which regulatory decisions can assimilate equitable considerations, the role of discretion in each of those regulatory techniques, and its somewhat different role in an exceptions process.

First, regulatory equity may be achieved through rule formulation. A rule can be written to include equitable standards, such as "reasonableness," that invite situation-specific judgments when it is applied. A rule can also be fine-grained, dividing the regulated population into a large number of discrete categories eacli of which is treated differently. 46 An existing rule, of course, can also be reformulated or repealed so that it no longer apphes to situations that experience has shown to deserve special treatment.

Second, regulatory equity may, within certain limits, be achieved through rule interpretation. Thus, an agency that has occasion to decide what a rule means or to whom it applies can take equitable considerations imto account when it renders that decision. In stressing certain facts rather than others or in manipulating the level of generality at which elements of the rule are to be pitched, for example, the agency enjoys considerable latitude about whether to include or to exclude particular parties. Certain regulatory methods facilitate this individualization of rules through interpretation. For example, the requirement that a license or permit be obtained before a particular activity is undertaken is often designed to allow situational factors to be incorporated into the decision as to whether and under what conditions the license or permit should be granted. 47

Third, regulatory equity can be introduced through rule enforcement. This is not quite the same as rule interpretation. Even in situa-

46. Under the Natural Gas Policy Act of 1978, for example, natural gas is divided into more than ten categories, each of which is entitled to separate price treatment. 15 U.S.C. $\$ \S 3312-3348$ (1982).

47. See Federal Water Pollution Control Act, 33 U.S.C. $\$ 1311(b)(2)(A)(1976)$, Regulations at 40 C.F.R. $\$ 125.30$ (a) (1982)(the permits required under the federal Clean Water Act). 
tions in which the language and purpose of the rule may be perfectly clear and may be unambigously applicable to a particular firm or person, agency officials may consider situational factors im deciding whether, when, and in what manner to enforce the rule against a particular violator.

Finally, regulatory equity can be introduced by creating a formal exceptions process for the explicit purpose of considering applications for rehef from particular rules. Whether the relief that this process grants is described as an exception, waiver, special relief, variance, or exemption, the technique is essentially the same. An exceptions process, as we shall see, also employs rule formulation, rule interpretation, and rule enforcement techniques in performing its tasks.

Discretion plays an essential but distinctive role in each of these regulatory equity techniques. When a rule is formulated, discretion may be implanted in the standards contained in it. The role of discretion in rule interpretation is often more ambiguous and only implicit. The official interpreting the rule, for example, may not be willing to acknowledge, indeed may not be aware, that she is makmg certain choices, such as selection of the relevant facts, that neither precedent nor logic strictly compels. Decisions as to which rules to enforce and against whoin obviously require that discretion be exercised, but that discretion may be quite separate from whatever discretion is contained in the formulation or interpretation of the rule itself. The latter may be perfectly transparent and nonproblematic. Indeed, prosecutorial discretion is often governed by factors, sucli as resource constraints and compliance patterns, that have nothing to do with the rule's meaning.

In a formal exceptions process, discretion plays yet another role. There, the process itself assumes that the rule, as formulated and interpreted, does apply to a particular situation and presumably will be enforced as such. In that context, discretion does not operate upon the rule but is only invoked to determine whether that situation qualifies for special dispensation under the legal standards governing exceptions relief.

It is tempting to view this as a distinction without a difference, to conclude that the use of discretion in the exceptions process simply effects a reformulation, reinterpretation, or nonenforcement of the rule. This view, however, ignores several important poimts. The first concerns the moral meaning of rules. It is one thing to say that a rule does not apply to $A$, and quite another to say that the rule does apply to $A$ but will be suspended in A's case for certain equitable reasons. In the first case, A's conduct (and that of others similarly situated) is being justified rather than condemned. The moral content of the rule, there- 
fore, is being altered. In the second case, however, the moral content of the rule is affirmed; it continues to condemn the proscribed conduct but excuses A from liability or stigma on the basis of circumstances peculiar to $\mathrm{A}$ as an individual (and others similarly situated)..$^{48}$

A second distinction between discretion that acts directly upon a rule and discretion that is used in an exceptions process to decide whether relief froun a concededly applicable rule should be granted, relates to the institutional structure within which the decisions are made. An explicit exceptions process, where one exists, ${ }^{49}$ can assuune many different organizational forms. This article is principally concerned witl only one, in which an agency establishes an exceptions office that is to some extent structurally separate and independent from the program office that issues and administers the rules from which relief is sought. ${ }^{50}$ This kind of structural separation of rule and equity may express not only a fundainental psycliological ambivalence about the values that each embodies but also a principle of organizational function..$^{51}$ As we shall see, this separation also has important policy consequences, ${ }^{52}$ and thus applying discretion to the exceptions process rather than to the rule has important practical effects as well.

48. For a discussion of the distinction between justification and excuse, see Fletcher, Fairness and Utility in Tort Theory, 85 HARv. L. REv. 537, 557-64 (1972).

49. Soune agencies have no exphicit exceptions process at all. Examples include the National Labor Relations Board and the International Trade Commission. See Letters to Hon. Loren A. Smith, Chairman, Administrative Conference of the United States, from Hugh L. Reilly, Sohcitor, NLRB, June 21, 1983, and from Alfred Eckes, Chairman, ITC, June 8, 1983. In such cases, rehef from a rule may be obtained, if at all, only by petitioning the agency to repeal or modify the rule, see Administrative Procedure Act, 5 U.S.C. $\S 553(\mathrm{e})$ (1982), or by successfully resisting its enforcement administratively or in the courts.

50. In the federal government, another common form of exceptions procedure involves a hearing at some point in the exceptions application process before an independent admimistrative law judge. In such systeins, appeals from grants or denials (or both) by the ALJ inay ultimately be taken to the agency head (or commission), with review of the final agency decision by the courts. The adjustments process of the Federal Energy Regulatory Commission is an example. See P. SChuck, When the Exception Becomes the Rule, Report to the Administrative ConFERENCE OF THE UNITED STATES, at app. A (1983). Another model allows for direct application for exceptions relief froin a rule to the rulemaker itself (the program office or agency head). See, e.g., id. at app. C. The Supreme Court recently had occasion to consider the status of an application for an exception directed to a court. See District of Columbia Court of Appeals v. Feldman, 103 S. Ct. 1303, 1313 (1983)(request to court for waiver of bar examination rule requires court to evaluate purposes of rule and therefore requires a "judicial" decision).

51. See infro notes 90-94 and accompanying text. Having created an apparatus of logical rules, Thurman Arnold argued, we continue to feel the need to create "separate institutions to represent common sense and benevolence." T. ARNOLD, supra note 14, at 62.

52. See infra notes $425-30$ and accompanying text. 


\section{Regulatory Equity and Judicial Equity.}

The pursuit of equity in the regulatory process has certain obvious parallels to the more familiar, traditional phenomenon of judicial equity through case-by-case adjudications..$^{53}$ Both processes are animated by similar concerns about the limited ability of rules alone to achieve justice in particular cases. Both reflect some similar values and possess soine common features. For example, each resolves particular disputes through adjudications that are legitimated in part by the use of explicit reasoned justifications subject to review by higher authority. Each process is informed through oral and written arguinents developed through adversarial techniques. Each recognizes the relevance and authority of statutes, rules, prior cases, and other decision materials.

The significance of these similarities between agency and court adjudication is increasing at a time when Congress characteristically leaves courts to adjudicate witliout inuch statutory or constitutional guidance. Nevertheless, the differences between the ways in which courts and agencies deploy equitable values are at least as important as the apparent similarities, underscoring the distinctive character of regulatory equity. They also suggest wlyy a specialized administrative organ or arrangement is often necessary to infuse regulatory equity imto the administrative process.

1. Institutional Purpose. The dominant purposes of courts and agencies differ. ${ }^{54}$ Characteristically, courts adjudicate the rights and obligations of disputants on the basis of principled justifications and distinctions derived from previously adopted legal norms. It is true, of course, that courts often advert to considerations of social policy, and to the predicted consequences of a decision for persons and interests not before the court. This occurs not only in public law litigation but increasingly in private law litigation as well. Despite the relevance of extra-litigation factors, lowever, the canons of the judicial craft and the requirements of judicial legitimacy continue to focus the court's analysis upon the claims of the parties before it. This naturally inclines the

53. By judicial equity, I refer not to the system of remedial justice traditionally administered by separate courts of chancery, but rather to the process by which courts that engage in common law adjudication mtegrate conceptions of situational justice into their decisions and thus into the resulting structure of legal rules.

54. These differences are underscored by the fact that regulatory agencies are often created to perform a task that common law courts previously performed but performed (or so the legislature thought) poorly for reasons having to do with limitations imposed by the courts' methodology, values, or institutional character. See, e.g., Clean Water Act of 1977, Pub. L. No. 95-217, 91 Stat. 1566 (codified at 33 U.S.C. $\$ \S 1251$-1376 (Supp. V 198I)); National Labor Relations Act, Pub. L. No. 74-198, 49 Stat. 449 (1935)(codified at 29 U.S.C. $\$ \$ 151-166$ (1976)). 
court toward a situational, particularistic orientation rather than toward more generalized policy prescriptions. When a court seeks equity, it does so by refining existing principles, carving out exceptions to them, or developing competimg ones enbodying a different array and weighting of values.

A regulatory agency, in contrast, is an engine of continuous social policy formulation and impleinentation. Although obliged to render neutral, principled decisions with respect to individual disputes brought before it, an agency's principal purpose is to effectuate an externally created but bureaucratically internalized legislative purpose, usually the protection of certain collective values or group interests. Thus, the Civil Aeronautics Board was established to promote the interests of the nascent airline industry, the Equal Einployment Opportunity Commission to advance the rights of minorities, and the Environmental Protection Agency to safeguard the environment. This orientation encourages agencies systematically to undervalue particularized justice in favor of the social interests and policy goals that they are required to pursue through their regulatory prograins. These interests and goals usually transcend those of the particular parties before them. .5

2. Types of Rules. Common law adjudication often requires judges to devise new principles or rules where existing ones cannot fairly resolve a dispute or where no plausibly applicable rule exists at all. But the rules that courts elaborate through case-by-case adjudication typically differ im important respects from those that agencies develop in rulemaking - and even from those that they apply in agency adjudication. Agency rules are limited only by the very permissive contours of a typically broad and ainbiguous statutory standard. An agency is permitted, even expected, to promulgate legislative-type rules that reflect the exercise of discretion, judgment, specialized knowledge, and pohitical choice. Thus, agency rules often plunge into new policy realms, boldly occupying unfamiliar terrain and mapping it through a more or less comprehensive set of prescriptions. In such cases, justification need not rest upon principle, except insofar as the statute broadly supphes one; it is ordinarily enough that the rule not be inconsistent with the statutory standard and that it meet minimal standards

55. See, e.g., Shepard v. NLRB, 103 S.Ct. 665, 670 (1983) (whereas a court of general jurisdiction will be more likely to grant a successful party's prayer for complete relief, an agency, even in the context of adjudication, need not order complete relief if it has legitimate policy reasons for limiting relief). 
of rationality. Policy considerations, as mediated by agency "expertise," are thought to supply the necessary ingredients of decision.

In contrast, the kinds of rules that courts develop through case-bycase adjudication tend to cling parasitically to familiar moorings, only incrementally inodifying solutions that have already been framed. Although it is commonplace for an agency to decide, for instance, that trucks on imterstate highways shall be no inore than 65 feet in length, it would be extremely unusual for a court to devise such a rule itself. That is the kind of particularized choice that a democratic society does not expect unelected generalist judges to make. ${ }^{56}$

There is an intriguing irony here, one highly relevant to the problem of regulatory equity. Although conceived as broad exercises of discretion, agency rules often take the form of relatively rigid, detailed prescriptions. Particularized justice cannot be achieved directly through such forms but only through an auxiliary mechanism, such as an exceptions process. Judicial rules, im contrast, are fashioned by tribunals whose discretion is systematically, indeed constitutionally, limited. Courts steadfastly refuse to acknowledge that they exercise discretion even (perhaps especially) when they clearly do. Yet the rules that emerge from this relatively constrained process usually take the form of general formulations whose flexible contours can easily accommodate the palliating impulses of situational justice. Agencies tend to spawn hard-edged rules that resist the solvent of further discretion; an equitable capacity must therefore be added. Courts, while eschewing discretion, tend to produce tractable, malleable rules capable of absorbing equitable claims as they arise in individual cases.

3. Decision Procedures. Given their distinct purposes and products, it is hardly surprising that the procedures and doctrines of courts and regulatory agencies differ significantly; procedures, after all, are intended to reinforce an institution's dominant goals even as they are shaped by those goals. Most court adjudication, for example, is structured to focus attention narrowly upon the claims of individual litigants rather than upon a decision's larger social consequences. The rules of evidence, the boundaries of the record, and principles such as

56. For an unusual and extremely controveŕsial "exception" to this proposition, one that perhaps "proves the rule," see Roe v. Wade, 410 U.S. 113, 164-65 (1973)(prescribing different substantive standards for each trimester of pregnancy). See also the brace of cases defining the minimal number of jurors constitutionally permitted for crimmal prosecutions: Ballew v. Georgia, 435 U.S. 223, 245 (1978)(five are too few); Williams v. Florida, 399 U.S. 78, 103 (1970)(six are enough). In reapportionment cases, the courts, as a result of their "one person, one vote" standard, have felt obliged to make exceedingly fine-grained numerical choices. See, e.g., Karcher v. Daggett, 103 S. Ct. 2653, 2660-65 (1983). 
those governing standing, ripeness, and intervention, for example, all reinforce this traditional, constrained view of the judicial function. Divergences from this inodel, of course, are increasingly countenanced, even encouraged. This does not mean that the model is incoherent or fails to describe most of what courts do, but only that it is under pressure to adapt to new functions traditionally associated with agencies and legislatures. ${ }^{57}$

For most regulatory agencies, however, individual dispute resolution is decidedly ancillary to the discretionary, policy development function, ${ }^{58}$ a fact strikingly revealed in those agencies, most notably the National Labor Relations Board (NLRB), that rely upon adjudications almost exclusively as a mode of decision. ${ }^{59}$ The powerful interest in yoking an agency's procedures to its policy objectives is demonstrated by the broad administrative discretion to reverse policy direction and abandon precedent retroactively ${ }^{60}$ through adjudication despite the potential injustice to individual parties. Agencies are also permitted to adjudicate without the procedural safeguards of independence and objectivity characteristic of courts. ${ }^{61}$ Far from being a source of illegitimate bias, the regulatory agency's policy commitments, its pervasive politicization, are mobilized so that the agency may better achieve its purposes. ${ }^{62}$ The agency thus systematically subordinates the values of neutrality, principled decisionmaking, and particularized justice to the demands of a politicized, pragmatic policy instrument that seeks to transform certain domains of reality in prescribed ways.

57. See P. Schuck, Suing Government: Citizen Remedies for Official Wrongs 19698 (1983).

58. Of course, the vast majority of discrete decisions that agencies make involve neither the development nor the issuance of rules but rather the application of rules to particular firms or individuals. See generally Verkuil, A Study of Informal Adjudication Procedures, 43 U. CH1. L. REV. 739 (1976). This fact, however, only underscores the disproportionate significance to most agency policymaking of the relatively small number of rules that exist or are under development at any particular time, a significance augmented by the fact that agency rules are usually intended to influence a broader range of private decisions than court or agency adjudications.

59. Commentators have almost universally condemned this approach. See, e.g., Mayton, The Legislative Resolution of the Rulemaking Versus Adjudication Problem in Agency Lawmaking, 1980 DUKe L.J. 103, 103 (1980); Note, NLRB Rulemaking: Political Reality Versus Procedural Fairness, 89 Y ALE L.J. 982 (1980); see also sources cited supra note 6.

60. See, e.g., NLRB v. Bell Aerospace Co., 416 U.S. 267, 290-95 (1974).

61. For example, agencies inay dispense with ALJ decisions, 5 U.S.C. $§ 557$ (b) (1982), and, under certain conditions, with cross-examination. 5 U.S.C. $\$ 556$ (d) (1982). In "infornal adjudication," APA procedural requirements do not apply at all. The extreine case may be the Immigration and Naturalization Service. See Schuck, The Transformation of Immigration Law, 84 Colum L. Rev. 1, 31-34 (1984).

62. By politicization, I mean the circuinstances of the agency's creation, its statutory setting, continuous congressional oversight, the appointment and recruitment processes, and its constant and intensive interactions with outside interests. 
4. Organizational Forms and Settings. Even in an age of burgeoning judicial caseloads and complex forms of litigation, a court remains a remarkably solitary decisionmaker. ${ }^{63}$ In the federal courts, at least, judges ordinarily employ only a small retinue of law clerks and researchers to assist them; in state courts, even a single clerk may be a luxury. Judges' physical and intellectual isolation mirror the traditional, limited conception of their function. Judging is viewed as a lonely, insulated, highly personalized task in which one applies logical and analytical powers, the corpus of legal rules, distillations of principle, and divinations of equity to the record. The record-principally evidence and arguments-has already been intentionally circumscribed by the procedures and conventions of litigation. Legal arguments are abstracted from the larger world of political struggle and social consequences, and drawn into the artificially confined world of the courtroom and the particular parties.

The contrast between this relatively closed, unpopulated milieu and the dense, teeming environment in which regulatory officials make decisions could hardly be more striking. From their perches in the organizational hierarchy, regulators preside over a swarın of bureaucratic, policy-generating activity. Their decisionmaking machinery, unlike that of judges, is highly differentiated-by function (e.g., policy development, enforcement, research), by programinatic subject matter (e.g., water, air, pesticides), by geography (e.g., field operations, state and local programs), and by other dimensions of specialization (e.g., legal counsel, economic analysis).

That courts exhibit little or no functional differentiation, and that agencies display a great deal, directly affects the way in which each goes about reconciling the competing claims of rule and equity. In the courtroom, particularity finds a limited sanctuary from the generahizing impulse of the outside world. The dominant judicial ethos holds that parties are entitled to corrective justice meted out to them as individuals, rather than to decisions that merely treat them as imstances of an abstract class or category. Particularity looks to what they have done, not to the social interests that they may be said to represent. Rules of evidence, norms of relevance, the generality with which rules are often formulated, the availability of several rules from which the judge may choose, the importance of fact-finding to rule application, and other aspects of the judicial process reinforce this individuated conception of justice; they confine the court's attention to the parties' unique behavior

63. Thoughtful commentators are concerned that this unique condition may be changing. See, e.g., Fiss, The Bureaucratization of the Judiciary, 92 YALE L.J. - (July 1983)(forthcoming). See generally McCree, Bureaucratic Justice: An Early Warning, 179 U. PA. L. REv. 777 (1981). 
and condition, keep rules at the perimeter of the judge's field of vision, and enlarge the scope of individuated justice.

In a court, the trier of fact also integrates the conflicting clains of rule and equity. As ad hoc decisionmakers without continuing life or responsibilities, juries are probably less preoccupied with maintaining a system of legal rules than with dispensing situational justice. ${ }^{64}$ To a lesser extent, this is also true of judges, who do not systematically supervise any speciahized policy system and who receive little feedback concerning how their equity-infused decisions affect the integrity or effectiveness of rules.

If courts respond primarily to claims of situational justice, regulatory agencies tend to undervalue or neglect such claims. Most agencies implement policy primarily through rulemaking, rule application, rule enforcement, and activities supportive of these functions, such as research. Some, like the NLRB, formulate their policies almost exclusively through rules adopted in individual case-by-case adjudications. ${ }^{65}$ Rules are an agency's most visible, controversial and cluaracteristic product, the focus of its political, legal, intellectual and social concerns. Congress, the media, regulated interests, "public interest" activists, and other attentive groups will evaluate an agency's performance almost exclusively in terms of the presumed consequences of its rules. Rules, in short, are an agency's center of gravity, its raison d'etre.

The agency's pursuit of situational justice, in contrast, is a relatively subordmate enterprise. More a constraint than a defining purpose, equity is the regulator's landfall, not lier lodestar. In some agencies, equity receives no special structural expression at all. ${ }^{66}$ In others, an exceptions process exists but it is preoccupied witl relatively narrow, ad hoc, discrete adjudications decidedly ancillary to the central rule-related activities. ${ }^{67}$ Coordination of regulatory equity and regulatory policy tends to occur, if at all, only sporadically at the upper levels of the hierarcliy, far from the routinized disposition of exceptions cases. Regulatory equity, therefore, demands inore than simply accominodating rule-based and situational justice, difficult as that is. When an agency bureaucratizes the process of justice-seeking and fragments the domains of rule and equity into specialized structures, it has created a formidable organizational problein. Unlike a judge, who coinbines

64. See G. Calabresi \& P. BobBit, supra note 38 at 57.

65. See supra note 59. There are combinations of these basic patterns. The Iminigration and Naturalization Service, for example, designates certain of its adjudicatory decisions as "precedents," thereby creating the functional equivalent of a rule. See Diver, supra note 10, at 95.

66. See supra note 49.

67. See e.g., P. SCHuCK, supra note 50, at app. G. 
these strivings in herself, an agency must somehow find a bureaucratic way to integrate the conflicting conceptions of justice that these specialized structures express.

\section{Regulatory Equity and Policymaking Through Agency Adjudication.}

When regulatory equity is pursued in the context of an exceptions process, it takes the form of a particularized adjudication of the rights of individual claimants (or a class of similarly situated claimants) by the agency's exceptions tribunal. Not all agency adjudication, however, is designed to achieve regulatory equity in the "situational justice" sense in which I have defined it. Adjudication may also be used to pursue the agency's broader pohicy goals. Indeed, as noted above, all regulatory agencies use adjudication to elaborate and enforce their policies to some degree, and a few develop policy almost exclusively through the adjudicatory process. ${ }^{68}$

Despite the important differences in context and norms noted earlier, ${ }^{69}$ agency adjudication in pursuit of broader goals resembles comnon law court adjudication. Like common law judges, agencies often develop rules by a gradual, case-by-case process of inclusion and exclusion, of lime-drawing and classifying, as new fact situations come before the tribunal for decision. Through this process, general regulatory primciples and policies become more and inore determmate, hardcning into specific agency rules.

This article will not rehearse the spirited arguments about the virtues and demerits of increinental agency policymaking through common law-type adjudication. Those arguments are well-presented in the scholarly literature. ${ }^{70}$ Instead, I wisl to empliasize a point that is easily obscured by certain formal similarities between common law-type agency adjudication and exceptions adjudication inentioned earlier. The former, properly understood, has essentially nothing to do with the pursuit of regulatory equity. The purpose of common law agency adjudication is to develop policy that can guide conduct in a relatively large number of future cases, not to avoid an unjust or anomalous outcoine in a particular case. Common law agency adjudication thus cannot be legitimated in the saine way as equity-seeking exceptions adjudication. The procedures necessary to legitimate the former must be designed to

68. See supra note 59 .

69. See supra note 38 and accompanying text.

70. See, e.g., Strauss, Rules, Adjudication, and Other Sources of Law in an Executive Department: Reflections on the Interior Department's Administration of the Mining Law, 74 COLUM. L. REV. 1231, 1258, 1274-75 (1974); see also sources cited supra note 3. 
elicit a policy-oriented information base and broad public participation, not a situation-specific record, a narrow party orientation, and an emphasis upon procedural fairness to individuals.

One must be careful, then, not to conflate what are actually two very distinct forms of adjudication that demand very different analytical and normative frameworks. This is difficult, however, for at least two reasons. First, at a formal level, these two types of adjudications resemble one another. Thus, the distinction between regulatory equity through exceptions, on the one hand, and policy development through adjudications, on the other hand, is far clearer analytically than it is empirically. Exceptions process adjudications can be understood as points arrayed on a continuum. Professor Aman has attempted to characterize this continuum by identifying three broad categories of exceptions decisions. Aman calls them "hardship," "fairness," and "policy" exceptions. In Aman's scherne, "liardship exceptions" focus primarily upon individual, unique characteristics of the applicant. "Fairness exceptions" do so as well but take particular account of the applicant's relationship to the program's regulatory goals and of the program's impact upon others similarly situated. "Policy exceptions" emphasize not the plight of particular applicants but the regulatory program's overall goals. ${ }^{71}$ Obviously, one could describe numerous intermediate points along the continuuin representing hybrid forms.

Typically, the exceptions process is established to adjudicate "hardship" cases, cases in which applying a rule to an individual would work mjustice because the rulemaker failed to anticipate such an application and the rule's purpose would not really be served by it. This is regulatory equity proper. But such cases can shade imperceptibly into Aman's "fairness" domain, in which the situational justice considerations animating the decisionmaker are somewhat less weighty and the policy-sensitive considerations are soinewhat more so. At some further point, also reached by subtle gradations of motive and orientation, the exceptions decision may seek not merely to achieve that rule's purposes more fully but to achieve agency policy goals that transcend the purposes of the rule from which relief is being sought. I have been at pains to emphasize that this "policy exception" is not regulatory equity, properly understood. But it can easily be mistaken for-and misrepresented as-a "hardship exception," which is regulatory equity proper. Even to the exceptions agency, it will not always be obvious where on the continuum a case should be located, especially in the early stages of adjudication.

71. Aman, supra note 6, at 293. 
The second reason why regulatory equity and policy development through common law agency adjudication are easy to conflate is that both the exceptions apphicant and the agency may be tempted to counterfeit the decision process by passing the latter off as the former. This is an especially promising strategy when, as in the DOE, the same bureaucratic unit performs both functions. The applicant's motivation for doimg so is not difficult to imagime. The classic canons of adjudication, after all, encourage a hitigant to portray his case as one involving a relatively narrow, situational claim rather than a broad policy issue. By exploiting the actual ambiguity of the hardship/fairness/policy exception boundaries, the applicant can often render this portrayal credible. The agency's incentives to adopt a similar strategy are equally powerful but considerably niore complex. They require, therefore, a more extended analysis.

To an important extent, largely overlooked by scholars, ${ }^{72}$ the use of the exceptions process for policymaking purposes can be understood as an administrative response to a set of constraints upon informal ruleunaking under the Administrative Procedure Act. Ironically, these constraints have been imposed largely in the name of "regulatory reform." To a policymaker who wishes to change the prevailing regulatory course quickly, informal rulemakmg is increasingly a process to be avoided. The APA requires the agency, at a ininimum, to publish a notice of proposed rulemaking inviting written comments from interested parties, to "consider" those comments, and to publish the final rule to be effective at least thirty days thereafter. ${ }^{73}$ The resulting rule is subject to judicial review ${ }^{74}$ and may be stayed pending sucli review. ${ }^{75}$ Although the notice and public procedure requirements, as well as the 30-day preeffectiveness period, may be waived upon certain agency findings, ${ }^{76}$ these findings are themselves subject to judicial review. ${ }^{77}$ Particular statutes may augment the APA procedures with additional requireinents. ${ }^{78}$

72. For an exception, see Strauss, supra note 70, at 1245-48.

73. 5 U.S.C. $\$ 553$ (1982).

74. 5 U.S.C. $\$ 702$ (1982).

75. 5 U.S.C. $\$ 705$ (1982).

76. 5 U.S.C. $\S 553(\mathrm{~b})(3)(\mathrm{B})$ (1982). -

77. See, e.g., American Federation of Government Employees v. Block, 655 F.2d 1153, 1155 (D.C. Cir. 1981).

78. These include, for example, requirements that the agency publish advance notice of proposed rulemaking or provide oral hearings with more or less procedural formality, multiple rounds of proposed rules, longer comment periods, or reports to Congress. Legislative veto provisions have also become commonplace. But see Immigration and Naturalization Serv. v. Chadha, 103 S. Ct. 2764 (1983). 
In recent years, a variety of cross-agency "regulatory reform" measures-primarily statutes and Executive Orders-have burdened agency rulemaking with additional analytic procedures and layers of administrative review, including requirements for an environmental inpact stateinent, ${ }^{79}$ and a regulatory impact analysis satisfactory to the White House staff. ${ }^{80}$ Particular regulatory statutes go even further. The Consumer Product Safety Commission, for example, must consider, analyze and make findings with respect to the effect of each of its rules upon many coinplex factors, and must publish these analyses along with the rule. ${ }^{81}$ These requirements, of course, are themselves directly or indirectly subject to judicial review. ${ }^{82}$

Despite the extensive procedural, analytical, and pohitical hurdles that must now be surmounted before an agency rule may be issued, its survival in the courts is by no uneans assured. This is true even when the scope of judicial review is narrow, as under the typical "arbitrary and capricious" standard.83 Indeed, during the 1970's, the lower courts imposed substantial procedural requirements going well beyond those prescribed by the APA. ${ }^{84}$ At least some of these additional requirements evidently survived the Suprene Court's decision in Vermont Yankee Nuclear Power Corp. v. Natural Resources Defense Council,

79. National Environmental Policy Act, 42 U.S.C. $\$ 4332$ (c) (1976).

80. Executive Order 12,291, 3 C.F.R. 127 (1982).

81. 15 U.S.C. $\& 2058$ (c), (f) (1982).

82. 15 U.S.C. $§ 2058(f)(4)$ (1982). Rules developed by the DOE, for example, are subject to especially time-consuming procedures. Under the Department of Energy Organization Act, each rule proposed by the DOE must be accompanied by a statement of the research, analysis, and other available information in support of, the need for, and the probable effect of the rule, and a response to the "major comments, criticisms and alternatives offered during the comment period." 42 U.S.C. $\S 7191$ (b) (d) (Supp. V 1981). Such requirements are unusual but not unique. See, e.g., Consumer Product Safety Act, 15 U.S.C. § 2058 (1982).

In addition, the Secretary of Energy cannot issue rules until he first notifies the Federal Energy Regulatory Commission (FERC) of the proposed rules. If the FERC determines that the rules may significantly affect FERC functions, the Secretary must refer the rule to the FERC; the FERC must then invite additional public comment on the proposal and publish its recommendations, along with its own explanations of reasons and analysis of comments. Only after the FERC's recommendations are published can the DOE issue the rule. 42 U.S.C. $\$ 7174$ (Supp. V 1981). The necessity for formal references under section 7174 is minimized by a process of informal clearance with the FERC. Whether formal or informal, however, the process demands precious time.

If the DOE rules are economically and politically significant, as has often been the case, they must ordinarily be submitted for informal review by the White House policy staff. The regulations altering the base period for motor gasoline allocations during the 1979 shortage is an example. See infra notes $268-81$ and accompanying text.

83. The Supreme Court recently confirmed this proposition. See Motor Vehicle Mfrs. Ass'n v. State Farm Mut. Auto. Ins. Co., 103 S. Ct. 2856, 2866 \& n.9 (1983).

84. For an account of this evolution, see Scalia, Vermont Yankee: The APA, the D.C. Circuit, and the Supreme Court, 1978 SUP. CT. REv. 345, 348-52 (1979). 
Inc. , further increasing the vulnerabitity of rules on appeal. ${ }^{85}$ But even where a rule is ultimately upheld on appeal, the delay in confirmingand if a stay pending appeal is granted, in implementing - the rule can be lengthy.

In short, mformal rulemaking, which began as an open-ended, discretionary process analogous to a legislative hearing, ${ }^{86}$ has evolved into a highly formalized, procedurally complex, rationalistic, and often quite protracted process. ${ }^{87}$ This development casts a new light on what has been perhaps the central tenet of administrative reformers for decades-the notion that agencies should be encouraged, and in some instances required, ${ }^{88}$ to elaborate agency policy through rulemaking rather than case-by-case adjudication. ${ }^{89}$ But as pressures for increased formality, more extensive records, and analytical rigor have dissipated many of the much-celebrated virtues of informal rulemaking, certain advantages of case-by-case adjudication in general, and of exceptions adjudication in particular, have come to seem correspondingly great.

Some of these advantages are intrinsic to agency adjudication. By limiting the impact of decisions to their particular facts, agency adjudication facilitates cautious and fiexible policy development and exploits incrementalism's considerable political and intellectual virtues. 90 In primciple, agency adjudication limits the scope of factual inquiry, demanding fewer analytical resources than rulemaking and consuming less time. But case-by-case adjudication also has extrinsic advantages, peculiar to particular administrative contexts. In the context of DOE policymaking, for example, these advantages go far toward explaining the power, prominence, and aggressive use of an exceptions process.

85. See, e.g., United States Lines, Inc. v. Federal Maritime Commission, 584 F.2d 519, 53435 (D.C. Cir. 1978)(agency required to disclose specifically any data relied on in reaching an admimistrative decision, in order to facilitate judicial review).

86. See Scalia, supra note 84 , at $346-47$.

87. Legislation that passed the Senate 94-0 during the 97th Congress, but was not enacted, would have made rulemaking procedures and analytical requireinents even more complex, rigorous, and time-consuming than they already are, and would have applied them to the independent regulatory commissions as well as to executive branch agencies. See S. 1080, 97th Cong., 2d Sess., 128 Cong. Rec. 52,713 (March 24, 1982).

88. See, e.g., NLRB v. Wyman-Gordon Co., 394 U.S. 759, 764 (1969). For a criticism of this approach, see Strauss, supra note 70, at 1265-66.

89. See, e.g., K. Davis, Discretionary Justice 54-60 (1969). See generally sources cited supra note 53.

90. See D. Braybrooke \& C. Lindblom, A Strategy for Decision 88, 99-100, 111-12 (1963); see also Diver, Policymaking Paradigms in Administrative Law, 95 HARv. L. Rev. 393, 399 (1981). As Professor Strauss points out, adjudication can also defeat the bureaucratic inclination to defer difficult decisions. Whereas a rulemaking can often be put off indefinitely, a case that is before the agency must be decided. Strauss, supra note 70 , at 1254. 
First, policymaking by way of adjudication is particularly attractive where an agency's regulatory jurisdiction extends to a broad subject matter or to numerous and diverse regulated firms or individuals. ${ }^{91}$ As a practical matter, such an agency must regulate through very general rules which must apply to many firms whose objective circumstances may differ quite radically. Even rules of this character are not infinitely elastic; they cannot be stretched to encompass such diversity without working some mjustices. They are imevitably overinclusive. Hardship exceptions must be available to accommodate these "bad fits," and this can only be accomplished on a case-by-case (or perhaps a class-by-class) basis.

This jurisdiction-related temptation to proceed by case-by-case adjudication is even stronger when the program is conceived to be emergency in nature.92 In such situations, rules must be issued quickly, often in wholesale lots. ${ }^{93}$ Hastily prepared, overbroad rules can be disastrous for those who technically are covered by the rules but to whom the rules should not, in justice or sound policy, be applied. Inflexible application of such rules may quickly create grave competitive distortions, perhaps even driving firms out of busmess before the rules can be refined or eliminated. Again, if relief is to be granted im such cases, adjudication will be necessary to identify the speciflc situations in which the rule pinches. Furthermore, emergency programs are usually expected to be of short duration, remaining in effect only so long as the exigent conditions persist. Thus, an agency may regard the delay, analytical requirements, personnel demands, and other costs associated with developing a rule as unjustified or simply prohibitive.

Agency adjudication may also seem particularly attractive when the rulemaking process is ineffective for any of a number of intellectual, bureaucratic, or political reasons. An agency, for example, may be paralyzed by uncertainty as to what policies to adopt, unable to mobilize the bureaucratic machinery at its command, or unwilling to run the pohitical risks that difficult policy decisions often entail. Where

91. For example, the DOE's regulatory jurisdiction was sweeping with respect to both subject matter and number of firms. Its authority embraced all aspects of the pricing and allocation of crude oil and petroleum products at all levels of production and distribution by literally hundreds of thousands of firms. See infra notes 100-26 and accompanying text.

92. Agam, petroleun regulation provides a vivid example. See infra notes $108-09$ and accompanying text. Whether the petroleuin regulatory program as a whole responded to or created and exacerbated an emergency situation (or both) is an important question, but one that I shall not address in this article. For sharp cricitisms of the program, see sources cited infra note 96.

93. The basic petroleum price and allocation regulations under the Energency Petroleum Allocation Act (EPAA), for example, were issued in a batch within weeks of the law's enactment. They essentially replicated the earlier Phase IV regulations. 10 C.F.R. $\S \S 202-215$ (1975). 
hard choices must be made but the rulemakers cannot or will not make them, the decisions may fall by default or delegation to adjudicators.

Finally, agency adjudication typically enjoys lower visibility and hence greater freedom from outside control than rulemaking. In certam contexts, this may constitute an important advantage to cautious policymakers. Even where policymakers possess the capacity and will to make hard choices, they may nonetheless wisl1 to limit their exposure to political reprisals for unpopular decisions. In such cases, they may search for a bureaucratic cover or buffer that can deflect criticism over controversial decisions away from theinselves. ${ }^{94}$ Because agency adjudication purports to affect only one or a few firms or individuals, it seldom invites widespread public participation, media coverage, or congressional scrutiny; moreover, it can be readily reversed or limited in future cases if that should seem prudent. Adjudication, unlike policymaking, can also wrap itself in the mantle of judicial legitimacy and independence. Regulatory equity is a more appealing slogan than regulatory change.

Several points about the above discussion should be stressed. First, these particular advantages of the case-by-case approach tend to be distributed in a highly skewed fashion; they accrue almost exclusively to the agency, not to regulated firms or the general public. ${ }^{95}$ The disadvantages of adjudication, however, are borne in just the reverse pattern. For example, a body of law or policy is less comprehensible, predictable, or subject to public criticism when it only evolves case-bycase, and when participation may be costly. Adjudication's skewed distribution of benefits and costs, combined with the growing administrative burdens associated with rulemaking, means that agenciesespecially those with broad regulatory jurisdiction, politically controversial policies, emergency authority, and a disabled rulemaking apparatus-will often find adjudication a congenial vehicle for policy development. As we shall see, DOE met all of these conditions. Not surprisingly, it adopted this decisionmaking strategy with entliusiasm. Its tactical instrument for doing so was process.

Second, many of the considerations that make rulemaking seem madequate as a regulatory tool may imply not that case-by-case adjudication is a superior mode for implementing regulatory policy, but that the particular market should not be subjected to regulation of a

94. See, e.g., Note, supra note 59, at 987-99.

95. Of course, certain other advantages of adjudication-for example, its greater accuracy with respect to so-called "adjudicatory facts"-inure to the public as well as to the agency. 
command-and-control variety at all. ${ }^{96}$ In this view, regulatory inequity is so pervasive in such a program that an exceptions process attempts to use band-aids to staunch a massive hemorrhage. In the analysis that follows, however, I shall not question the wisdom or legitimacy of the regulatory program but shall analyze the exceptions process on the assumption that the program of which it was a part was congressionally mandated and therefore legitimate.

\section{E. Regulatory Equity and the Exceptions Process.}

In this part, I raise some fundamental questions about the role of exceptions in the regulatory process, questions that the remainder of this study will address. They may be organized around five related problems.

1. The Problem of Functional Integration. Does the exceptions process simply serve the situation-oriented, particularistic concerns of equity in particular cases, or does it also implicate the agency's larger policymaking functions? If the exceptions process affects both, how does the agency manage to integrate equitable and policy developinent purposes without sacrificing the distmctive values of each?

2. The Problem of Organizational Integration. Does the bureaucratic organization of the exceptions and rulemaking processes affect the way im which the agency's rules are formulated, interpreted, and enforced? Does that organizational structure affect the way in which exceptions decisions are actually made? Does it solve the problen of functional integration? What values are served and sacrificed by that particular structure?

3. The Problems of Equitable Criteria and Legitimacy. How can the exceptions process establish and preserve legitimacy and integrity in a decision context that invites imputations of favoritism, political pressure, ad hoc judgments, and unequal treatinent?

4. The Problem of Procedures. Does the exceptions process einploy procedures that are adequate to the kinds of tasks that it under-

96. Although an evaluation of the merits of regulating the petroleum industry in the manner that Congress directed is far outside the scope of this article, it bears notmg that the program was repeatedly criticized by economists and others as being inherently flawed and inevitably counterproductive. See, e.g., K. ARrow \& J. Kalt, Petroleum Price Regulation: Should We DeCONTROL? 46-47 (1979); S. BREYER, REgUlation AND ITS REFORM 120-30 (1982); FEDERAL ENergy Administration Regulation: Report of the Presidential Task Force I39-46 (P. MacAvoy ed. 1977). 
takes? Are its procedures appropriate both to the pursuit of regulatory equity and to common law-type agency adjudication? In particular, how can it organize what is an essentially adjudicatory process to generate decisions that are not only procedurally fair to individual parties but also expeditious and sensitive to political and policy factors?

5. The Problem of Accountability and Control. What roles do other institutions - the department, the Congress, the courts, and private groups-play in structuring and influencing the various functions that the exceptions process exercises? How well do these other institutions actually perforn them and how should those roles be altered?

After examining microscopically the exceptions process in action in Part II and analyzing those findings in Part III, I shall return to these problem areas in Part IV, using them as analytical foci for evaluating the exceptions process.

\section{The Exceptions Process And Energy Policy}

To comprehend the functions and significance of the exceptions process in federal energy regulation, we inust first examine the program of energy regulation in which that process was embedded and the formal organizational structure of which it was a part.

\section{A. The Petroleum Industry and Federal Regulation. 97}

Since the first oil wells were drilled at Titusville, Pennsylvania in 1859 , the American oil industry has become the inost complex in the world, an extraordinarily intricate network of companies and activities linking crude oil sources and consumer markets, both foreign and domestic. Industry activities fall into four general categories: production (exploration for and removal of crude oil from natural formations); refining (the manufacture of crude into gasoline, motor oil, heating oil, petrochemicals, and other intermediate and end-use products); distribution (physical transportation, storage, handling, and delivery of pe-

97. The brief discussion that follows provides only the most schematic description of the petroleum industry and its regulation. The draft prepared for the Administrative Confcrence of the United States (ACUS) contains more details. See supra note 50. For an even more comprehensive survey, see generally ENERgY Policy in Perspective: Today's Pronlems, Yesterday's Solutions (C. Goodwin ed. 1981) [hereinafter cited as ENERGY PoliCy]; J. KALT, The Economics and Politics of Oil Price Regulation (1981); Petroleum Regulation Handbook (J. Bell ed. 1980); W. Lane, The Mandatory Petroleum Price and Allocation REgulations: A History AND ANALYSIS (1981). 
troleum products); and marketing (sales of approximately 500 refined products to wholesale and retail customers).$^{98}$

Different segments of the mdustry combine the four basic activities in various ways. Approximately fifteen to twenty large, usually multinational companies integrate all four operations. This group (Exxon, Gulf, Texaco, and others-cthe majors" in industry parlance) dominates the industry. In September 1981, for example, the fifteen largest imtegrated refiners processed nearly 70 percent of all motor gasoline and approximately 55 percent of middle distillates-a decline in both categories from 1972 but still accountimg for the majority of refinery production. Independent refiners, which produce little or none of the crude they refine, processed the remainder. Independent refiners range from small firms, with capacities as low as 10,000 barrels per day (BPD), to large independents, like Ashland Oil, with a capacity as high as $400,000 \mathrm{BPD}$, rivaling the integrated companies' capacities. Geographically, refiners tend to cluster near port facilities, major markets, or large domestic oil fields..$^{99}$ In less densely populated regions, such as the Midwest and Rocky Mountain states, small and independent refiners often process a relatively large proportion of total product.

The first federal efforts to regulate the petroleum industry attempted to buttress state regulations. In the 1930's, Texas and other states initiated "conservation" measures to stabilize domestic oil prices by controlling production levels. Congress then enacted the Connolly "Hot Oil" Act, ${ }^{100}$ prohibiting the interstate transportation of product in violation of state laws.

98. The major products include naphtha (used for jet fuel), propane and butane (used as aviation fuel and in chemical processes), notor gasoline, aviation gasoline, middle distillate fuel oil (including lighter grade home heating oils, diesel fuel, kerosene, and range oil), residual fuel oil (a heavier fuel oil often used in industry), asphalt, road oil, and coke.

Although most large refiners distribute and market their products over a wide area or even nationwide, others, such as Ashland Oil and Sohio, operate in well-defined marketing regions where they enjoy a large inarket share. Both crude and product markets are affected by substantial imports; the New England market for residual fuel oil, for example, receives much supply from Caribbean refineries. In the specialized motor gasoline inarket, refiners market only about $16 \%$ of their product directly to bulk purchasers or through refiner-owned retail outlets. The other $84 \%$ goes to "independent marketers," consisting of dealers that lease stations from the refiner or own their own stations and market under the refiner's brand, and "jobbers," who buy gasoline at wholesale and either market it themselves (branded or unbranded) or sell it to other stations. The proportion of total branded and unbranded product sold to jobbers rose to over $50 \%$ between 1972 and 1981, reflccting regulations that favored jobbers and a national trend toward discount "gas and go" stations run by jobbers. Jobbers traditionally rely upon the independent refining sector for most of their supply.

99. The largest center, on the Texas-Louisiana Gulf Coast, supplies a large portion of the Midwest and East Coast inarkets. Refining centers around Los Angeles, San Francisco, and Seatthe supply most of the West Coast and Rocky Mountain states. Other major refining areas include the eastern Pennsylvania-New Jersey region and the Chicago area.

100. 49 Stat. 30 ch. 18 (1935), codified at 15 U.S.C. $\$ 715$ (1982). 
After World War II, as Uinted States production capacity increased substantially, foreign supplies began to reduce domestic oil prices. The federal government responded with voluntary import quotas, and in 1958 the Mandatory Oil Import Program (MOIP) was adopted, imposing binding quotas.101 Combined with the state "conservation" laws, these quotas stabilized domestic crude prices at levels well above prevailing world prices. Although the MOIP differed from the economic controls of the 1970's, which sought to hold domestic prices below world levels, many features of the MOIP continued in the controls program despite the vastly altered environment.

Three continuities are particularly worth noting. First, the MOIP protected the domestic refining industry by restrictimg imports of refined products while permitting imports of crude. An important exception to the import restriction was that East Coast imports of residual fuel oil were allowed, apparently for political and pollution control reasons and to permit oil to compete with coal for generating electricity; the East Coast refiners were thus discouraged from producing residual fuel oil. This favorable treatment for East Coast product imports was contimued in the entitlements program and is still reflected im the low production of residual fuel oil by East Coast refiners. Second, the MOIP allocated imported crude quotas among domestic refiners on a basis that benefitted small refiners, an advantage later continued in the "small refiner bias" of the entitlements program, discussed below. Finally, the MOIP was used to promote a number of other domestic policy objectives also pursued in the 1970's controls, including developing the Puerto Rican economy, encouraging low-sulfur fuel imports for environmental reasons, and preserving independent marketers in the Northeast.

By 1973, the MOIP had outhved its usefulness. World prices were gradually mcreasing to domestic levels, domestic excess capacity was disappearing, and localized shortages had appeared. In April 1973, President Nixon amended the MOIP to phase out quotas by 1980 and to estabhish a new import fee system. ${ }^{102}$ The same factors that led him to curtail the MOIP, however, also created pohtical demands for more comprehensive regulation of domestic prices. These demands were met in March 1973, when special controls were imposed on the petroleum industry.

The petroleum industry had already been subject to the economywide anti-inflation controls under the Economic Stabilization Act of

101. Bell, Introduction ro Federal Petroleum Regulation, in Petroleum Regulation HandBooK supra note 97 , at 1 .

102. Id. at 3. 
1970, introduced in August 1971 as Phase I. ${ }^{103}$ These controls, relaxed somewhat when Phase II was introduced in November 1971,104 were removed administratively in Deceinber 1972 (Phase III), ${ }^{105}$ and for a brief period the petroleum industry, along with the rest of the economy, was free of federal controls. But only three inonths later, in response to pressures on crude and product prices, the administration reimposed selected controls. An economy-wide price freeze followed in June $1973^{106}$ ("Phase III $1 / 2$ "), intended to last for 60 days until the Cost of Living Council (CLC) could establish a new systein of mandatory price controls for the entire econoiny.

In August 1973, the CLC issued the Phase IV regulations, ${ }^{107}$ the first ever developed specifically for the industry. These imposed mandatory price controls on crude oil and petroleuin products. Crude oil was divided into two tiers: "old" oil, the price of which was controlled at May 1973 levels plus 35 cents per barrel; and "new" oil, which could be sold at market prices. Refiners could increase their prices only to the extent that prices of their own product inputs increased. Phase IV was expected to be temporary; in fact, it turned out to be temporary for all sectors other than the petroleum industry. It did not impose allocation controls. Some shortages had developed during the wimter of 1972 and smaller, independent refiners who did not control their own crude sources were seriously concerned. Independent marketers, which had benefitted from the previous period of surplus domestic crude, now faced potentially severe dislocations and also sought protection from shortages. Bills granting to the President power to address this problem had been introduced in Congress earlier that year, and when the Arab oil embargo was imposed in October 1973, an allocation program became inevitable.

On November 27, 1973, Congress, acting in a crisis atmosphere, enacted the Emergency Petroleum Allocation Act (EPAA), ${ }^{108}$ extending the 1970 price control authority as it applied to the petroleum industry and adding new authority for comprehensive allocation controls. EPAA remained the basic federal statute governing the petroleum imdustry from 1973 to 1981 . It did not prescribe any particular form of price or allocation controls but delegated to the President ex-

103. Pub. L. No. $91-379$, tit. II, 84 Stat. 799 (1970)(codified as amended at 12 U.S.C. $§ 1904$ (1982).

104. See Bell, supra note 101, at 3.

105. Id.

106. Id.

107. Id.

108. Pub. L. No. $93-159,87$ Stat. 627 (1973), codified at 15 U.S.C. $\$ 751$ (1982). 
tremely broad authority to develop and promulgate regulations. ${ }^{109}$ On December 4, 1973, the Federal Energy Office (FEO) was created by Executive Order to prepare and implement the regulations mandated by the EPAA. 110 Authority to administer the Phase IV controls was transferred to the FEO three weeks later. On June 27, 1974, the Federal Energy Administration (FEA) Act ${ }^{111}$ became effective. This Act established the FEA as the successor agency to the FEO and contained administrative and substantive provisions concerning the price and allocation regulations. In October, 1977, the FEA was superseded by the DOE.

The price regulations administered by the FEO and the FEA under the EPAA imcorporated the Phase IV regulations. The two-tier pricing systein for crude oil continued, while refiner prices and unargins remained frozen at May 15, 1973 levels, with price increases allowed only to the extent of imcreased costs. Marketers, subject to an original ceiling price frozen as of August 1, 1973, were also allowed to pass through the increased product costs resulting from rising world crude prices. The initial allocation regulations were publislied on January 15, 1974. These regulations froze commercial relationships in the distribution chain for crude and petroleum products, and allocated supplies at each level based on historical purchase patterns. ${ }^{12}$

109. As provided by section 4(b)(1) of EPAA, Pub. L. No. 93-159, 87 Stat. 627 (1973), codified at 15 U.S.C. $\$ 753(b)(1)$ (1982), the regulations must "to the maximum extent practicable . . . provide for-

(A) protection of public health . . . , safety and welfare . . . ;

(B) maintenance of all public services . . . ;

(C) maintenance of agricultural operations . . . ;

(D) preservation of an economically sound and competitive petroleum industry . . .;

(E) the allocation of suitable types, grades and quality of crude oil to refineries in the

United States to permit such refineries to operate at full capacity;

(F) equitable distribution of crude oil, residual fuel oil, and refined petroleuin products at equitable prices annong all regions and areas of the United States and sectors of the petroleum industry ....;

(G) allocation of residual fuel oil and refined petroleum products in such amouuts and in such inanner as may be necessary for the inaintenance of, cxploration for, and production or extraction of-

(i) fuels, and

(ii) minerals essential to the requirements of the United States ... ;

(H) economic efficiency; and

(I) minimization of economic distortion, inflexibility, and unnecessary interference with market inechanisms.

110. Exec. Order No. 11,748, 3 C.F.R. 376 (1974).

111. Pub. L. No. 93-275, 88 Stat. 96 (1974), codified at 15 U.S.C. § 761 (1982).

112. Producers were required to continue selling to the refiners with whon they had dealt on the effective date of the freeze, December 1, 1973. Domestic refiners, in tura, were obligated to continue supplying the distributors to whom they had sold during the corresponding month of calendar 1972, the "base period." Finally, distributors and refiners were obligated to continue supplying end users who were base period bulk purchasers of product. 
In addition to this general allocation freeze, crude was allocated among refiners under the "buy/sell" program establislied on February 1, 1974. The program, designed to ensure that all domestic refineries operated at the same proportion of their refining capacity, allocated the total amount of available crude among refiners according to current refining capacity. Refiners whose ratios of production to capacity were in excess of the national average supply-to-capacity ratio were required to sell their excess to those whose ratios were below average. ${ }^{113}$

A second crucial regulatory policy toward refiners was the "entitleinents" program, established in Deceinber 1974. Because individual refiners' access to price-controlled crude varied, their input and product costs differed substantially under the regulations. Even under normal conditions, these differences could severely affect competition; in a shortage situation, refiners without access to price-controlled oil could soon be driven out of business. A refiner's access to old oil usually depended upon its supply contracts and relationships with producers. The larger, more integrated companies usually, though not invariably, had the greatest access to controlled crude. Texaco, for example, benefitted from its own large doinestic production, and inany small refiners had long-term contracts for domestic crude, but otlier refiners depended heavily on foreign contracts. ${ }^{114}$ In order to lessen these cost and competitive disparities, the FEA required refiners with good access to price-controlled crude to subsidize those with poor access to it until crude cost differences resulting from differential access were essentially eliminated.

Initially, each refiner received a nuniber of "entitlements" to buy old oil."15 Entitlements had a fixed, uniform value. Refiners that purchased low-cost old oil for themselves had to make payinents (i.e., had to purchase entitlements) to raise the net cost of their crude to the national average cost per barrel. Refiners that bought uncontrolled oil or imported crude could receive payinents (i.e., could sell entitlements) to lower the cost of their higher-priced crude to the national average.

113. Sales were to be made at the sellers' weighted average acquisition cost, plus a small handling fee. Allocations were made quarterly; during the February-April 1974 quarter, the first under the program, 56 million barrels of crude changed hands under the program.

114. An example was Ashland Oil Co.; see infra note 234 and accompanying text.

115. The number of entitlements was based upon a company's crude runs to stills (i.e., the quantity of crude it had refined) multiplied by the average proportion of old oil processed in all refineries nationwide, known as the National Old Oil Supply Ratio. The FEA and later the ERA admimistered the entitlements program by publishing a monthly list that stated low many entitlements each refiner was permitted to sell or required to buy. In order to base entries in the entitlements list on actual rather than projected statistics on processing by refiners, the agency pubhished each list approximately two months subsequent to the month to which the list applied. 
As originally conceived, the value of entitlements was based on only two price "tiers," derived from the average prices of controlled and uncontrolled crude. At least in theory, competition would determine how the crude within each tier would be distributed. To a large extent, the entitlements program was designed to benefit the small refiners. Their pohtical influence had already enabled them to extract not only a "bias," granting them extra entitlements under the regulations, but also an opportunity to apply for special exceptions rehef under the DeltaBeacon standards, discussed in Part V. Indeed, for a brief period im 1975-1976, small refiners received a full exemption from entitlement purchase obligations, and when the FEA withdrew the exeinption, it remstituted the small refiner bias at an even higher level and continued to grant exception relief.

Allocation programs were also established for motor gasoline and for distillate. When the Arab oil embargo was imposed at the beginning of the 1973-1974 heating season, distillate supplies needed for heating, agriculture, and other essential services were very low; significant spot shortages had occurred the previous winter. Energy regulators encouraged distillate production rather than gasoline production, probably exacerbating shortages of the latter, and then allocated distillate among users. ${ }^{116}$ Gasoline allocation was similar in many respects to distillate allocation, but did not attempt to reach all end users. ${ }^{117}$ Lines at gasoline pumps, which became notorious during January and February 1974 and in the spring and summer of 1979, performed this function.

When the Arab boycott ended in the spring of 1974, the crude shortage that spawned the EPAA quickly disappeared. Although no more severe shortages occurred until 1979, the intervening increases in world prices created substantial differentials between world prices and domestic controlled prices. To have allowed domestic prices to rise to world levels would have rapidly increased domestic product prices transferring wealth from consumers to crude producers, most of whom had made their investınents in the far different economic climate fos-

116. Distillate was allocated first to priority users, at a level equal to their current requirements, and then to all other users on the basis of complex formulae that took into account both consumption during a representative historical period and presumed conservation effects.

117. Priority users (e.g., agricultural production, emergency services, energy production, sanitation services, telecommunications, and transportation services) were entitled to $100 \%$ of their current gasoline requirements. All other wholesale and end-use bulk purchasers were entitled to $100 \%$ of their consumption in the base period, the corresponding month im 1972. Three percent of a state's total supplies was set aside for the state's allocation office to distribute. Retail gasoline outlets were left to compete for whatever supplies remained-a volume estimated to be about $20 \%$ below forecast normal demand during the first quarter of 1974. 
tered under the MOIP. Unwilling to countenance either of these results, Congress instead chose to extend the EPAA, first briefly in September $1975^{118}$ and again in the Energy and Policy Conservation Act (EPCA) of 1975, ${ }^{119}$ which set a final expiration date of September 30, 1981. The disparity between world and domestic prices also enabled energy regulators, largely through the entitlements program, to create a system of monthly transfers between refiners involving over two billion dollars annually. ${ }^{120}$ This prograin generated intense support for continuing controls ainong small refiners and other seginents of the industry that benefitted from regulation.

Between the enactinent of the EPCA in 1975 and the beginning of the Iramian supply disruption in late 1978, Congress passed several additional laws affecting petroleum prices and allocation, most notably the Energy Conservation and Production Act of 1976 (ECPA) ${ }^{121}$ and the Department of Energy Organization Act of 1977 (DOE Act). ${ }^{122}$ The ECPA extended the FEA for 18 inonths, to Deceunber 31, 1977, modified the crude pricing formula under the EPAA, exempted crude from "stripper" wells (those producing ten barrels per day or less) froin controls, and sought to stimulate tertiary production. The DOE Act merged the functions of the FEA, the Energy Research and Development Administration, the Federal Power Commission, and parts of several other departments and agencies to form a cabinet-level Departınent of Energy. As part of this consolidation, the FEA's oil regulatory functions were transferred to a new Economic Regulatory Administration (ERA) within the DOE.

Even more important than the statutory changes during this period were the administrative ones. The price and allocation regulations were formally ainended over 200 times in the seven years following their promulgation in January 1974, and many of these changes were extreinely complex. Two-tiered pricing for crude, begun in 1973, evolved into a far more intricate system. Refiner pricing becaine elaborate. After the Arab embargo, regulatory changes transformed the buysell prograin froin one designed to equalize all refiners' access to crude supplies into a means by which the 15 major integrated refiners were to supply, on a pro rata basis, the aggregate volume of crude to which a designated number of refiner-buyers were entitled. By 1979, only a

118. Emergency Petroleum Allocation Act of 1975, Pub. L. No. 94-99, 89 Stat. 481 (1975)(codified at 42 U.S.C. $\$ 6201$ (1976)).

119. Pub. L. No. 94-163, 89 Stat. 871 (1975)(codified at 42 U.S.C. $\$ 6201$ (1976)).

120. The agency was able to use the entitlements program, as we shall see in Part V, to advance various ancillary policy purposes.

121. Pub. L. No. 94-385, 90 Stat. 1125 (1976)(codified at 42 U.S.C. $\$ 6801$ (1976)).

122. Pub. L. No. 95-91, 91 Stat. 565 (1977)(codified at 42 U.S.C. $\$ 7101$ (Supp. V. 1981)). 
subset of small independent refiners (as defined by the EPAA) qualified as refiner-buyers eligible to receive buy-sell program allocations.

After 1976, doubts grew on Capitol Hill and at the DOE about the economic justifications for special benefits for small refiners. Exceptions rehef for small refiners was curtailed, the small refiner bias built into the entitleinents program was reduced, and the pool of entitlements funds was increasingly used to meet objectives other than the equalization of crude costs. ${ }^{123}$ The exceptions process itself was used to subsidize, among others, producers of California heavy crude, Puerto Rican naphtha, and gasohol.

By 1979, then, the "temporary" structure established to regulate price and allocation during the 1973-1974 emergency lad grown exceedingly complex and deeply entrenched. Both Presidents Ford and Carter had indicated a desire to end controls and many DOE officials had agreed. Decisive action, however, was prevented by the political influence of small refiners and other beneficiaries of regulation, Congress's suspicion of the major oil companies and its desire to maintam low prices, and bureaucratic self-interest at the DOE. An additional shock was needed to precipitate decontrol, and the Iranian Revolution supplied it. The three month halt of Iraman oil exports in late 1978 and early 1979 created a shortage of only three to five percent of U.S. supply; the 1973-1974 shortfall had been more than twice as great. Yet the 1979 shortfall, exacerbated by a cumbersome and anachronistic regulatory structure, produced gasoline sliortages in sonie areas that were more severe than in the previous crisis. ${ }^{124}$ Obviously, the need for a inajor policy change had become urgent.

In the short run, the shortage and gasoline lines simply ushered in a new generation of regulations. 125 Spasmodic changes in the price and allocation rules for motor gasoline and distillates generated bitter criticism because they created uncertainty and revealed regulatory incompetence. In addition, the absence of Iranian oil, along with production slowdowns by Saudi Arabia and otler Organization of Petroleum Exporting Countries (OPEC) nations during the late 1970's, pushed world crude prices in the spot market to levels far above contract prices, an unusual phenomenon for the industry. Many imdependent refiners were hard-pressed to compete with refiners that had access to domestic-

123. These objectives included, among others, the subsidization of producers of Alaskan North Slope (ANS) crude, new refiners, producers of petroleum substitutes, importers of residual fuel oil from Caribbean refiners, Puerto Rican naphtha producers, and purchases of crude to fill the Strategic Petroleum Reserve.

124. See infra notes 268-326 and accompanying text (for a detailed discussion of this episode).

125. This regulatory response is discussed in Part V, infra. 
controlled crude or foreign contract crude. Because the entitlements program simply averaged the prices of foreign contract, spot market, and all other forms of uncontrolled crude in calculating refiners' benefits and obligations under the program, it could not compensate those refiners forced to resort to the spot market for inuch of their crude. The buy-sell program, enhanced through additional allocations and increased in scope to help address this problem, and the OHA granted rehef im the form of substantial exceptions to a handful of large firms in a similar predicament.

But these were desperate expedients. The regulatory breakdown had demonstrated that the system would have to be dismantled. On April 5, 1979, President Carter introduced a plan to phase out the controls by September 30, 1981, when the EPAA was due to expire. Deregulation began on June 1, 1979 with the decontrol of newly discovered crude, the gradual conversion of lower tier crude to upper tier prices, and the gradual decontrol of upper tier crude. On January 28, 1981, President Reagan removed controls completely. He later both vetoed a bill that would have authorized the President to reimpose controls and sought to dismantle the DOE itself. Yet even at this writing, over three years after formal decontrol, the DOE continues to struggle with the vestiges of the regulatory system. ${ }^{126}$

\section{B. The Administrative Structure of the Exceptions Process.}

Although the Office of Hearings and Appeals (OHA) remaims remarkably unchanged simce its inception (under a different name) in 1973 , its position in the energy regulatory structure has changed. These changes have gradually increased its formal authority and institutional mdependence, while centralizing its decisionmaking.

OHA traces its authority to section 202 of the Economic Stabilization Act of 1970, which specified that the price regulations "may provide for the making of such adjustments as may be necessary to prevent gross mequities."127 Under Phase I of the controls, the Cost of Living Council (CLC), was authorized to "make exceptions or grant exemptions." 128 Beginning in Phase II, the CLC's two operatimg units, the Pay Board and the Price Commission, shared responsibility for considering individual exceptions apphications. Melvin Goldstein, a lawyer

126. Indeed, in the case of the entitlements program, the remaming "loose ends" concern the disposition of perhaps billions of dollars in subsidies. See Mobil Oil Corp. v. DOE, 520 F. Supp. 420, 429 (N.D.N.Y. 1981); see also supra note 4.

127. Pub. L. No. 91-379, 84 Stat. 796, 799 (1970), reprinted in 12 U.S.C. $§ 1904,2859$ app. (1970).

128. Exec. Order No. 11,615, §4, 3 C.F.R. 602, 604 (1971-75 Comp.). 
who had worked at the Price Commission and then (after a very brief stint at the Federal Trade Commission) at the FEO, helped to transform the exceptions function froin a rigid committee process into a less formal one emphasizing decisions written by individual analysts. When Congress established the FEO, it dispersed price exceptions authority among different agencies. ${ }^{129}$ In early 1974, the FEO created an Office of Exceptions and Appeals (OEA) to concentrate responsibility for all exceptions relief; ${ }^{130}$ Goldstein was named Director.

The Federal Energy Administration (FEA) Act of 1974 mandated a broader exceptions process, and the FEA placed the OEA within a new Office of Private Grievances and Redress (OPGR) ${ }^{131}$ along with a new Office of Special Redress, responsible for handling "those matters for which an appropriate regulatory process does not exist."132 This reorganization consolidated and extended Goldstem's authority, making him Director of the OEA and the OPGR as well as de facto director of the Office of Special Redress. The DOE Organization Act of 1977 placed the OPGR (renamed the Office of Administrative Review), the OAR, and the policy-making, enforcement, and regional offices under the Economic Regulatory Administration (ERA) within the DOE. When Goldstein threatened to resign unless his units were taken out of the ERA, the Secretary capitulated and established the "Office of Hearings and Appeals" under a delegation of authority running directly from the Secretary, not from the ERA Adininistrator.

Goldstein also wrote the order defining the OHA's jurisdiction. ${ }^{133}$ This order went into effect Marcl 30, 1978 and extended the OHA's authority in several ways. It retained the authority granted the Office of Admmistrative Review to issue exceptions, exemptions, appeals, special redress orders, modification and rescission orders, and stays of orders and rulings in its pending proceedings. It also obtained authority to issue final remedial orders in enforcement cases, following the

129. The IRS heard requests by retailers for price exceptions of less than one cent per gallon, and a unit in the FEO's Office of Planning and Policy considered all others.

130. The OEA was supposed to consider applications for exceptions, appeals from all orders issued by the FEO national office, and appeals from Regional FEO office decisions that presented issues of major economic or policy impact or established significant precedents. The OEA was also supposed to exaluate requests for exemptions, or "general exclusion[s] of a class of subjects from the scope of the regulations," which entailed "significant economic and other policy considerations." As soon as feasible, authority to consider retail price exception applications of less than three cents was transferred froin the OEA to the FEO Regional Offices.

131. The old Oil Import Appeals Board, responsible for considering appeals under the MOlP, was also placed within the OPGR.

132. See Memorandum from John Sawhill, FEA Administrator, to FEA Senior Staff and Regional Administrators, at 3 (Nov. 21, 1974).

133. DOE Delegation Order No. 0204-24, March 30, 1978. 
ERA's issuance of proposed remedial orders. It retained the power to review its own exceptions decisions, which had the effect of creating another hurdle for hitigants prior to FERC review. The OHA also received a general residual authority to "[c]onduct adjudicatory proceedings and issue orders in any instance in which a statute vesting authority in the Secretary requires an adjudication or appellate procedure and express Departmental procedures do not specify the manner in which the statutory authority is to be exercised."134

Perhaps most importantly, the new delegation order assured the OHA considerable autonomy froun other departmental policymakers. Previously, the only formal brake on OHA exceptions decisions, apart from the remote possibility of a Secretarial veto, was a requirement that an administrative review committee, consisting of the program office and the Office of the General Counsel, concur in every significant exceptions order before it could be issued. ${ }^{135}$ Disagreennent within the committee would trigger review by the Deputy Secretary or the Secretary. The new delegation order, however, allowed unilateral OHA action on "interlocutory orders" and "extension of relief previously provided," an authority that the OHA was to use in soine of its most important cases. ${ }^{136}$

Even with regard to final orders, however, the OHA was able to utterly dominate the cominittee process. During the early years of the exceptions process, committee clearance had brought other agencies' high level programmatic and policy expertise to bear upon exceptions decisions, but the OGC and the ERA later began to send subordinate staff to such meetings. Through a combination of argumentative skill and superior experience, Goldstein as chairman easily secured their agreement. Few issues were taken to the Deputy Secretary; when they were, Goldstein's persuasiveness and high standing with the Deputy Secretary almost always won the latter's assent. ${ }^{137}$ When the inotor gasolime erisis unleashed a flood of exceptions applications in the Spring of 1979 , cominittee clearance becaine too cunbersome to handle the great volume of cases, most of which were routme. The OHA

134. Id. at 3.

135. A Delegation Order of June 18, 1975 had excepted from the concurrence requirement relatively imsignificant orders, such as summary denials of applications, dismissals for failure to fill procedural requirements, "supplemental orders contemplated by the original order," and "decisions on requests for a stay of any order, regulation, ruling or other generally apphicable requirement which would otherwise apply to the applicant."

136. See, e.g., Ashland Oil, Inc. Nos. BEE-0373, BSG-0007 (Feb. 11, 1980)(discussed infra notes 233-47 and accompanying text).

137. Interview with John O'Leary, former Deputy Secretary, DOE (May 27, 1982); interview with William Funk, Office of General Counsel, DOE (June 30, 1982). 
instead circulated draft decisions to the OGC and the ERA; objections had to be received within 48 hours or concurrence would be assumed. The high volume of OHA decisions meant that the OGC and the ERA often could not meet that deadline; indeed, the lower-level ERA staff responsible for analyzing the OHA's drafts sometimes received them after the OHA's deadline had already passed. Although the ERA or the OGC sometimes extracted an extension of time, the deadline system enhanced the OHA's leverage.

Because the review committee mechanisin sometimes failed to integrate exceptions decisions into the larger departmental pohicy process, the DOE did not develop systeinatic approaches to certain important issues traversing ERA and OHA jurisdictions, such as motor gasoline allocation and the pricing of ANS crude. ${ }^{138}$ But even (indeed especially) when the review committee did function as an effective coordinating device, some of its procedures raised questions of procedural fairness. ${ }^{139}$

\section{The Exceptions Process in Action: Four Case Studies.}

The characteristic features and true significance of the exceptions process emerge most clearly in its application to specific areas of regulatory pohicy. In this Part, four detailed case studies are examined. The first study examines the OHA's ambitious efforts to subsidize small refiners through its so-called Delta-Beacon standards. These standards represent perhaps the most thoroughgoing, systematic instance of the use of "pohcy exceptions" in the service of a self-conscious, self-contained, and self-admmistered regulatory program. The second study examines the OHA's attempts to fashion "hardship" exceptions in two adjudications, the Union and Ashland cases, growing out of the lranian oil embargo of 1978-1979. The significant policy implications and enormous relief sought in these two cases challenged the OHA's conception of the proper role for exceptions in the larger policymaking process, and called into question the adequacy of its procedures. The third study, involving the Ohio Independents case, raises similar questions but in a rather different policy context. The final study examines the OHA's performance during the motor gasoline crisis of 1979 and

138. See infra notes $248-326$ and accompanying text.

139. Questions regarding OHA's refusal to disclose who was on the review committee, the committee's role in particular exceptions decisions, and the grounds upon which it altered decisions previously inade were not laid to rest by a Temporary Emergency Court of Appeals (TECA) decision holding that an applicant was not prejudiced by its inability to obtain this information from the DOE. Pasco v. FEA, 525 F.2d 1391, 1404-05 (Temp. Emer. Ct. App. 1975). 
the use of an exceptions process, especially in relationship to the OHA's use of the rulemaking apparatus, under conditions of severe stress.

1. The Delta-Beacon Program. The problem presented by the independent refining sector generally shaped the debate over the form of the entitlements program, and indeed over energy policy. As early as the MOIP, these refiners, lacking their own crude production facilities, had won some regulatory protection from normal market forces; their importance in the evolution of energy policy continued throughout the 1970s. 140

A combination of plausible economic arguments and unusual political advantages provided the independent refiners with great influence. Several of them had refinery capacities of several liundred thousand barrels a day, but the vast inajority were essentially small busmesses. Their geographical dispersion among a large number of congressional districts, as well as their ideological appeal as gallant competitors against the unajor oil companies (which politicians did not want to appear to favor) gave thein unusual political "clout" witl Congress and with administrations of both parties. The Justice Department strongly supported special treatment for sinall refiners in order to maintain competition in the petroleum industry. These refineries often served reinote communities in the West and Midwest where the major integrated companies were less active. Small refiners sometimes einployed a large proportion of the population in such communties. In many areas of the Midwest, agricultural production depended upon products from small refiners, such as farmers' cooperatives. The small and independent refiners wielded enormous influence on Capitol Hill, particularly when allied with groups that had related interests, such as the independent gasoline marketers that independent refiners often supplied and the East Coast independent terminal operators that supplied New England.

According to a Brookings Institution study, protection of the independent marketers, terminal operators, and refiners from the effects of tight doinestic and international markets "was the energy issue of 1973."141 The powerful lobby on behalf of these groups of independents inade the EPAA itself less a coinprehensive measure for administering during the shortage than an effort to help the independents weather the effects of both dried-up spot inarkets and reduced supplies

140. See supra notes 101-26 and accompanying text.

141. ENergy Policy, supra note 97, at 429. 
from the major integrated compames. ${ }^{142}$ The statute generously defined "small refiner" to mclude all those whose total refinery capacity did not exceed 175,000 BPD. 143 This mcluded all but the very largest mdependents, further testifying to the political strength of the refiners' lobby.

Once the EPAA passed, an explosive political debate occurred over the development of a crude cost equalization scheme. In July 1974, a group of twenty-eight senators inet with FEA Chairman John Sawhill to urge adoption of such a program in order to protect the independent sector. Members of Congress continued to lobby for the FEA in the succeeding months. The White House, fearing that support for decontrol might identify the Administration with the much-criticized major oil coinpanies, also helped push the FEA toward an entitlements program as the most reasonable alternative. ${ }^{144}$

Much of the discussion at the rulemaking stage focused on the special need to assure sinall refiners access to crude. The Justice Department's position echoed arguments by small refiners that their reliance on "new" (uncontrolled) oil had put them at a competitive disadvantage vis-a-vis the majors. ${ }^{145}$ The inajors, of course, controverted this point, maintaining that economies of scale and the small refiners' use of outdated technology made the latter inefficient. Yet it was difficult to ineet the arguinent that even the many small refiners with access to "old" (price-controlled) oil could not bear sudden large inereases in the cost of crude if those increases would trigger entitlements purchase obligations. The Justice Department and the small refiners, arguing for a full small-refiner exemption froin such obligations, eventually won small refiners a level of special benefits under the program equal to their maximum benefits under the old MOIP. Small refiners, as defined under the statutory terins, received a "small refiner bias" giving thein extra entitleinents under a sliding scale that awarded greater proportionate benefit as the refiner's production decreased. ${ }^{146}$

142. This purpose is revealed in the list of nine broadly worded goals of the EPAA. See supra note 109.

143. 15 U.S.C. $\$ 752(4)$ (1982).

144. ENERgY PolicY, supra note 97 , at $466-73$.

145. See Comments of the U.S. Dept. of Justice on Amendinent of FEA Regulations to Provide for Allocation of Old Oil, Sept. 30, 1974 [hereinafter cited as Justice Dep't Comments].

146. A refiner with an average daily throughput of $100,000 \mathrm{BPD}$, for example, received an additional $\$ 10,190$ in entitlenents daily, or approximately $\$ 0.10$ per barrel, while a refiner with average daily volume of only 10,000 BPD received $\$ 10,028$ inore in entitlements daily, or approximately $\$ 1.00$ per barrel. The FEA explamed that this bias was "necessary to compensate relatively small refiners for higher operating costs, proportionately greater capital expenditure requirements, and the fact that such refiners must, in many cases, market their products at a lower 
a. The origins of exceptions relief for small refiners. Although the fact was not apparent initially, the small refiner bias was only the first of a two-part subsidy of small refiners through the entitlements program. The second part, implemented through the exceptions process, soon followed. Even after the entitlements program was established on December 4, 1974,147 FEA officials continued to worry about how to justify the level of entitlements relief in the small refiner bias to the independent refiner lobbyists and their congressional supporters. The latter two groups had advocated a full exemption from entitlements purcliase obligations. Two weeks later, the FEA issued Special Rule No. 3 in an attempt to placate congressional and other advocates of small refiners. The rule sought to alleviate the "severe short-term economic impact" of entitlements purchase obligations on small refiners with higlier-than-average dependence on old oil. This was to be accomplished through a gradual phase-in of their purchase obligations over a three-month period. 148

At the same time, the FEA also announced that the OEA planned to grant exceptions rehef to small refiners "in a certain number of cases," and that the OEA was "already implementing an expedited process for the program." 149 In part, Special Rule No. 3 was intended to defer the full impact of entitlements purchase obligations until the OEA could fashion exceptions relief. Unlike the Special Rule, which was limited in effect to small refiners required to purchase entitlements (that is, those with a greater than average dependence on old oil), this announcement did not indicate the eligibility standards that the OEA would apply. The FEA hoped to preserve its flexibility, while reassurmg small refiners that it would not allow the entitlements program to put them out of business.

The OEA's first opportumity to grant exceptions relief to small refiners came in the Pasco Inc. case, ${ }^{150}$ decided January 20, 1975. Pasco filed for relief only two days after the entitlements program was established. It had entered the petroleum industry in 1973 after a federal antitrust consent decree forced the Atlantic Richfield Company (ARCO) to divest its assets in Sinclair Oil in order to foster competition im a 14-state area. ${ }^{\text {s1 }}$ In the entitlements program rulemaking, the Jus-

price than the products of the major branded refiners." 39 Fed. Reg. 39,740, 39,741-42 (Nov. 11, 1974).

147. 39 Fed. Reg. 42,246 (Dec. 6, 1974).

148. 39 Fed. Reg. 43,814 (Dec. 19, 1974).

149. $I d$.

150. Pasco, Inc., [2 FEA] ENERGy MGMT. (CCH) ๆ 83,021 (Jan. 20, 1975).

151. To buy Sinclair Oil, Pasco had invested all its assets and had borrowed $\$ 100$ unillion. Pasco had also incurred substantial long-term obligations under a rapid and extensive capital 
tice Department had specifically cited Pasco as an example of a small refiner with "heavy reliance on old oil" that would be injured by an entitlements purchase obligation. ${ }^{152}$ Although antitrust considerations may have made the case sui generis, Pasco contained at least tliree eleinents common to the first series of small refiner exception relief cases. ${ }^{153}$ First, relief was confined to refiners with greater than average access to old oil who thus were obliged to buy entitlements. Second, the criteria for relief eventually centered around a showing that a full purcliase obligation would have a severely adverse effect on the firmessentially a "serious hardship" standard. Finally, Pasco received relief from only a portion ( 52 percent) of its entitlements obligations, a benefit the OEA asserted would permit Pasco to "maintain its present market share and obtain the reasonable level of profits necessary to continue its capital improvement plans." 154

In Pasco the OEA had not announced a clear standard for small refiner exceptions relief but had merely indicated a willingness to consider individual hardship flowing froin entitlements obligations. By the end of January, several other small refiners had filed applications for exceptions relief and the FEA was acquiring a clear idea of what data it needed to decide cases more typical than Pasco. On February 10, the FEA publisleed a notice ${ }^{155}$ histing the information required in exceptions applications by small refiners. For small refiners that liad applied for exceptions relief, the lower level of entitlenents obligations that the Special Rule had allowed for all small refiners purchasing entitlements in November and December was continued pending a decision on per-

improvements program that included refinery and pipeline expansion, improvement of marketing facilities, and programs to increase its crude production.

152. Justice Dep't Comments, supra note 145, at 8. In its decision (Pasco, Inc., [2 FEA] ENERGY MGMT. (CCH) If 83,021 (Jan. 20, 1975), affd sub nom. Pasco v. FEA, [1974-1980 Transfer Binder] ENERGY MGMT. (CCH) ๆ 26,025 (D. Wyo. 1975), affd, 525 F.2d 1391 (Temp. Emer. Ct. App. 1975)), the OEA found that Pasco's capital improvements program was intended in part to "meet the goals specified in the divestiture decree," and that a full purchase obligation might cause Pasco to default on its financial obligations, posing "an immediate threat to the firm's continued existence." [2 FEA] ENERGy MGMT. (CCH) at 83,054-55. To jeopardize Pasco's effort to develop imto a viable competitor, the OEA reasoned, would frustrate the EPAA's purposes."

153. The use of exceptions relief to subsidize a capial development program distinguished Pasco from most other refiners that would receive relief under the OEA's "program."

154. Pasco, Inc., [2 FEA] ENergy MGMT. (CCH) If 83,021, at 83,057-58. When Pasco contested this limited relief in court, both the district court and the TECA affirmed the OEA's position that the EPAA contained goals other than enhancing competition, which justified requiring Pasco to "make certain sacrifices" that the entitlements program required of other refiners. See id. at 83,058; see also Pasco v. FEA, 525 F.2d 1391, 1400 (Temp. Emer. Ct. App. 1975).

155. 40 Fed. Reg. 6197 (Feb. 10, 1975). 
manent relief. ${ }^{156}$ This provision was apparently intended to invite additional exceptions applications. ${ }^{157}$

The notice also explained in general terms how the OEA intended to handle these applications. The usual exceptions standards of "severe hardship or gross inequity" would be applied to each application, and relief given to refiners "severely adversely affected by the program." But relief would be confined to small refiners required to purchase entitlements, a limitation that eclioed the earlier calls for a blanket exemption of small refiners from purchase obligations. FEA officials liad opposed such an exemption, preferring the small refiner bias for two reasons. First, the exemption would extend far more relief than was economically justifiable. Second, it would distinguislı arbitrarily between small refiner purchasers and sellers of entitlements. The FEA conceded that in the entitlements program's initial stages only the small refiners required to purchase entitlements would be hurt, for entitlements sellers received payments through the program. Yet once the entire industry became accustoined to tlie transfers under the program, it would become clear that the small refiners that sold entitlements were benefiting less from the program than the purcliasers that received exceptions relief. Entitlements sellers would have to spend their benefits on more expensive "new" crude, while entitlements purchasers receiving exception relief would enjoy the benefits of access to cheaper "old" oil without incurring any offsetting program obligations. As crude costs climbed during the late 1970's, the FEA's fears were realized. Exceptions relief to purchasers would secure them against financial loss, while other small refiners, differing only in their lower than average access to old oil, were exposed to fierce market pressures or compelled to apply for exceptions relief under the inuch stricter "serious hardship" standard.

b. Development of the Delta-Beacon standards. In the first months after the February 10 notice, the OEA decided several smallrefiner cases. These decisions indicate no uniformly applied standard for relief, nor any uniform method of calculating the appropriate level of relief. In general, the applicant's data must demonstrate a financial harm absent relief from entitlenents purcliase obligations, so severe as to threaten the firm's survival. Mohawk Petroleum Company, ${ }^{158}$ wlicli received one of the first small refiner exceptions after Pasco, was an

156. Id. at 6198.

157. The notice observed that the OEA had so far received "relatively few" applications from small refiners, "due perhaps to the complexities inherent in the startup phase of the program and the difficulties in drafting the necessary applications." Id. at 6199.

158. [2 FEA] ENERGY MGMr. (CCH) If 83,049 (Feb. 24, 1975). 
example. In Mohawk Petroleum Co., OEA found that a combination of the regulatory restrictions on diesel prices, the competitive market situation in other fuels, and a contractual agreement the company had reached concerning pricing for residual fuel oil would prevent the company from passing its entitlements costs on through higher prices. Although the company had generally been profitable, a full purchase obligation would threaten its "commercial viabihty."Is9

Despite the general strictness of the standard, the various criteria cited to demonstrate financial hardship in the early cases facilitated the grantimg of relief. Mohawk, for example, found evidence of the required hardship in effects upon working capital and monthly earnings. Beacon Oil Co. ${ }^{160}$ found it in effects upon operating profit and operating income. In denying exception relief in Navajo Refining Co. ${ }^{161}$ the OEA focused largely on the company's projected net income level and the level of profits in absolute dollars. Finally, in Edgington Oil Co. ${ }^{162}$ the denial was based upon a comparison of the company's projected profit margm after entitlements payments with its profit margins over the past five years. In none of these cases did the OEA exphicitly establish criteria for hardship, and the decisions made few citations to each other except to assert the general hardship standard. The OEA was experimenting. Different OEA analysts were assigned to different decisions and each was permitted to develop the approach he or she thought best. Refiners also submitted data in different forms, further impedimg consistent treatment.

In Pasco, the OEA had described its method of calculating the appropriate level of relief $\mathrm{i}$ an unpublished attachment, and this question received only cryptic treatment in decisions such as Mohawk and Beacon. ${ }^{163}$ Toward the end of the initial round of small-refiners excep-

159. Mohawk Petroleum Co., [2 FEA] EnErgy MGMt. (CCH) | 83,049, at 83,135 (Feb. 24, 1975). The strict standard of hardship applied in such cases, however, resulted in denials of relief in several other cases. See, e.g., Edgington Oil Co., [2 FEA] ENERGY MGMT. (CCH) ๆ 83,065 (Mar. 12, 1975).

160. Beacon Oil Co., [2 FEA] ENERgy Mgmt. (CCH) If 83,060 (Mar. 12, 1975).

161. Navajo Ref. Co., [2 FEA] EnERgY MGMT. (CCH) 183,069 (Mar. 12, 1975).

162. Edgington Oil Co., [2 FEA] ENERGY MGMT. (CCH) I 83,065 (Mar. 12, 1975).

163. In Beacon, [2 FEA] ENERGY MGMT. (CCH) \$ 83,060 (Mar. 12, 1975), its only explanation for granting $71 \%$ entitlements relief was that the figure was "[b]ased upon the financial data which Beacon has submitted relating to the firm's working capital position, operating profitability and cash flow." Id. at 83,173. Mohawk, [2 FEA] EnERGy MGMr. (CCH) 183,049 (Feb. 24. 1975), indicated that relief amounting to $63 \%$ of entitlements obligations would allow the company to attain a 1975 profit margin that "approximated" its profit margins over the past four years. Id. at 83,135-36. But the actual calculation of relief was based on various factors, including "the firm's historic return on equity, return on capital investment, working capital position, profitability, and cash flow." Id. at 83,135. Generally, these decisions did not explain how the OEA calculated relief as much as they demonstrated that a hardship existed, and that the OEA was determined to fulfill its statutory obligation to aid small refiners. 
tions relief cases at the end of March, OEA decisions increasingly focused on a comparison of historic and projected profit margims of applicants to calculate the appropriate level of relief, although they sometimes deviated from this test. 164

The FEA mailed to all 300 refiners in the entitlements program copies of a notice that it had published in the Federal Register proposing alternative standards for relief based on different measures of profitability, requesting comments on the proposals within approximately three weeks. ${ }^{165}$ Although it held a hearing, the broad notice and the request for comments suggest that the FEA was essentially conductimg a rulemaking process. Yet the FEA was evidently anxious to avoid adopting a formal rule at this stage, because that would transfer responsibility for administering the standards that the OEA had developed to another agency within the FEA while leaving the OEA to adjudicate exceptions to those standards. The FEA preferred to leave administration of the entire program of small refiner entitlements exceptions witl the OEA, whicli had already developed experience in the area. Because only a relatively small number of companies-no more than twenty at this tinie--iniglit qualify for exceptions relief, this would not over burden the OEA. Leaving developinent, as well as adjudication, of the standards to the OEA would also allow it maximum freedom to refine them furtler and to apply them flexibly in individual cases. Finally, Goldstein's aggressive pursuit of bureaucratic "turf" for the OEA supported keeping these standards as adjudicative grounds of decision rather than as formal rules. ${ }^{166}$

In the first of the next round of exceptions cases, Delta Refining Co., ${ }^{167}$ the OEA announced the standard that it had adopted in response to the comments received. The OEA agreed with those firns that preferred an alternative to the historic profit margin test, a stan-

164. See, e.g., Delta Ref. Co., [2 FEA] ENERGY MGMr. (CCH) I 83,078 (Mar. 28, 1975); Charter Oil Co., [2 FEA] ENERgy MGMT. (CCH) \ 83,077 (Mar. 27, 1975).

165. On August 4, the FEA had published a notice that, reflecting the predominant use of historic profit inargins in previous cases, assigned that criterion-more specifically, the average profit margin realized by a firm during the previous seven years-the status of a standard for relief. Despite past practice, however, the FEA felt that a test based exclusively on historic profit margins could, in the current period of rising crude and product prices, lead to calculations that failed to represent the true level of relief needed by some small refiners. As an additional standard, then, the FEA proposed either the firm's return on invested capital or its return on stockholders' equity. The level of exceptions relief granted would be based on the lesser of the historic profit margin on the two alternative standards the FEA adopted, unless the firm established that strict application of these criteria would not alleviate a serious hardship or gross inequity caused by the entitlements program. 40 Fed. Reg. 33,489 (Aug. 8, 1975).

166. Interview with John Hill, former FEA Assistant Administrator (July 29, 1982).

167. [2 FEA] EnERGY MGMr. (CCH) if 83,275 (Sept. 11, 1975). 
dard based on return on invested capital rather than one based on return on stockholders' equity: year-to-year shifts in the ratio of debt financing to equity inight distort the latter standard, but a comparison based on the former would achieve greater consistency. ${ }^{168}$ Application of this new "Delta standard" contributed to demal of relief to Delta and several other firms, but some initial grants were made for three inonths, until October 31,1975. The OEA then extended this relief to the end of 1975 in a single decision covering thirteen refiners, the majority of those that had been awarded Delta relief. ${ }^{169}$

By the end of 1975, exceptions relief for small refiners had systematically been transformed into a full-fledged subsidy program witl clearly stated, legislative-type criteria and a clearly defined constituency. Drawing upon a procedure strikingly similar to informal rulemaking under the APA, the OEA had crystallized and shaped its precedents into an explicit standard that would govern future adjudications of exceptions relief for small refiners. Developing the standard for exceptions relief through case-by-case adjudication had allowed the FEA great flexibility. At the outset, it had not been clear whether any particular standard would be appropriate, much less what such a standard should be. In this way, the FEA remained free to respond speciflcally to extreme cases in which entitlements obhigations might force firms out of business. Adjudication allowed exceptions analysts to experiment with different ways of approaching individual cases. Out of this experimentation, a body of primciples emerged that the OEA eventually adopted in rule-like form as the Delta standards. Thereafter, the individualized nature of exceptions proceedings would permit application of these standards in individual cases. ${ }^{170}$

c. Adjustment of Delta relief. By developing the Delta standards as it did, OEA created two kinds of problems. It sometimes applied standards that led to inconsistent treatment of different

168. The August 4 notice had also proposed that the FEA consider only data from petroleum refining and marketing operations in calculatimg what level of relief, if any, was appropriate. By eliminating data concerning crude production operations, this would avoid distorting "the financial position of the firm when viewed as a refiner," furthering the purpose of the entitlements program to reduce crude cost disparitics. The FEA adopted this approach. 40 Fcd. Reg. 33,489, 33,490 (1975).

169. Fannariss Oil Corp., [2 FEA] ENERGy MGMT. (CCH) 183,356 (Nov. 7, 1975). The decision also adjusted the relief for each of the companies to account for recent changes in the $\mathrm{Na}$ tional Old Oil Supply Ratio and the cost of entitleinents.

170. A court challenge to this prograin of relief foundered upon the usual rocks: the FEA's broad authority, the energy "einergency," and the "temporary" nature of the entitlements program. Cities Serv. v. FEA, 529 F.2d 1016, 1028 (Temp. Emer. Ct. App. 1975), cert. denied, 426 U.S. 947 (1976). 
companies and that were also inconsistently applied to individual con1panies over time. ${ }^{171}$ In addition, the Delta standard itself clearly dictated a change in the nature and quantity of relief to sniall refiners from that originally granted.

The OEA addressed these problems in two principal ways. First, it granted rehef on the basis of its most recent standard whenever a company appealed an exceptions decision on the ground of inconsistency. ${ }^{172}$ This technique, however, could secure consistency only for those refiners that took the trouble to appeal. To assure adjustment of relief for all companies, the OEA in 1976 began a year-end review that utilized both actual (rather than projected) figures and the latest standard. The adoption of the Delta standards had resulted in a different method of calculation of relief for all small refiners starting in September 1975, and the notice that proposed the Delta standards had treated them as superseding the criteria developed in the earlier cases. Consequently, the OEA proposed im the notice to use the Delta standards to consider afresh whether the relief granted earlier to small refiners had been imsufficient or excessive. ${ }^{173}$

In the spring of 1976, the OEA notified affected companies of the review and requested detailed financial information. 174 On August 30, it published a preliminary analysis and proposed adjustments for each refiner in the form of additional obhgations to buy or opportunities to sell entitlements. ${ }^{175}$ On November 5, the OEA issued a supplemental order ${ }^{176}$ making final adjustments simultaneously for the entire class of twenty-six small refiners that liad received exceptions relief in 1975. ${ }^{177}$

171. See supra notes $160-64$ and accompanying text.

172. Navajo Ref. Co., [2 FEA] ENERGY MGMT. (CCH) If 80,581 (May 2, 1975), presented such an appeal. The company claimed, inter alia, that the OEA had based its denial in part on calculations of profit margins as absolute dollar amounts, while in subsequent cases the OEA has calculated profit margins as a percentage of sales. In the decision on appeal, the OEA conceded that it had applied standards to Navajo that differed from those it applied subsequently. Using the latter method to calculate the company's profit margin and incorporating new materials submitted by Navajo, the OEA granted partial relief. See also OKC Corp., [2 FEA] ENERGY MGMT. (CCH) I] 80,850 (June 6, 1975).

173. 40 Fed. Reg. 33,490 (Aug. 8, 1975). Because the OEA had originally granted all exceptions based on firms' projections of their financial and market performance, and because refiners might distort their financial projections to obtain greater relief, a reevaluation on the basis of actual financial results would have been necessary even if the OEA had applied the Delta standards consistently throughout 1975.

174. See Delta Ref. Co. v. FEA, 559 F.2d 1190, 1193 (Temp. Einer. Ct. App. 1977).

175. 41 Fed. Reg. 36,540 (Aug. 30, 1976).

176. Beacon Oil Co., [4 FEA] ENERGY MGMT. (CCH) I 87,024 (Nov. 5, 1976). Supplemental orders, although not provided in the OEA regulations, were often used to modify prior orders, on the OEA's own initiative rather than that of any firm.

177. OEA added to or subtracted from the entitlements obligations in 1976 for all but two of the refiners. Husky Oil and Powerme successfully maintained that they should not be subject to 
This first year-end adjustment was challenged in court as a "retroactive recapture program" of which the FEA had failed to provide legally required notice to affected parties. The Temporary Emergency Court of Appeals decision upholding the OEA's practice, although predictable, seems highly questionable. ${ }^{178}$ The OEA's review, after all, did not simply update from projected to actual data but applied substantively different standards to that data. During the earlier proceedings, the FEA had never hinted that adjustment of relief would be based upon new standards. The court, however, simply ignored this problem, applying the extremely deferential standard of judicial review typical in DOE exceptions cases.

In addition to enforcing inconsistent standards, the amount of time required for the OEA to develop and apply the standards created problems. Frequent readjustments of rehef were necessary in response to changes im the entitlements program. The Navajo Refining case illustrates how the OEA attempted to incorporate such changes into its analysis. On the very day that the OEA denied exceptions relief in Navajo, the ERA had increased the cost of each entitlement from $\$ 5$ to $\$ 6$ to refiect rises in crude prices. When Navajo appealed, it contended that this imcrease made rehef appropriate, and the OEA used the new price of entitlements im granting partial relief on appeal. ${ }^{179}$ Because all companies receiving exceptions before the entitlements price increase had made similar claims, the OEA had to issue a supplemental order recalculating the amount of relief for each firm. ${ }^{180}$

retroactive application of the Delia standards, because they neither received relief nor applied for such relief again after the OEA began application of the new standards. The OEA found that it could rightfully apply the new standards to all 1975 exception relief granted the other refiners, because those companies had "voluntarily brought themselves under the standards" and had "accepted the benefits conferred upon them as a result of the application of those standards." [4 FEA] ENERGY MGMT. (CCH) I 87,024, at 87,078.

178. The TECA rejected the retroactivity argument, pointing to the following disclaimer in cluded in every decision and order granting exception relief: "This exception is based upon the presumed validity of statements, allegations and documentary material submitted by the applicant. It may be revoked or modified at any time upon a determination that the factual basis underlying the exception application is incorrect." Deita Ref. Co. v. FEA, 559 F.2d 1190, 1192 (Temp. Emer. Ct. App. 1977). The court also noted that certain decisions and orders issued in late 1975 (although not the one challenged) had given specific notice of a year-end review. Id.

179. See Navajo Ref. Co., [2 FEA] Energy MGMT. (CCH) ๆ 80,581 (May 2, 1975); Supplemental Order, [2 FEA] ENERGY MGMT. (CCH) I 87,009 (June 4, 1975).

180. See, e.g., Navajo, [2 FEA] Energy MGMT. (CCH) If 87,009 (June 4, 1975). Because the OEA extended previously granted relief every three inonths, it used these opportunities to adjust for changes in the entitlements program. The final extension of relief to 13 companies in October 1975 provided adjustments to reflect a further increase in the price of entitlements to $\$ 7.31$ and also a shift in the National Old Oil Supply Ratio that dictated whether a refiner would be obligated to buy or permitted to sell entitlements. See Navajo, [2 FEA] ENERGY MGMT. (CCH) $\|$ 83,356 (Nov. 7, 1975). 
d. Congressional influences. In 1975, the small refiners, having failed to persuade the energy agency to grant an exemption from the entitlements program, directed their efforts toward legislation. They maintained that not even the small refiner bias, and Delta-Beacon exceptions relief, had wholly lifted the burden of the entitleinents program from small refiners as a group. In particular, exceptions relief required a showing of severe adverse effect, and relief was only partial. In June 1975, for example, 34 small refiners had to pay almost $\$ 30$ million in entitlements, while 11 large oil companies were able to sell over $\$ 62$ million in entitlements. ${ }^{181}$ Such statistics, combined with skillful lobbying, persuaded Congress to amend the pending EPCA legislation to exempt refiners with a capacity of up to 100,000 BPD from all entitlement purchase requirements for their first 50,000 BPD. Congressional leaders in the energy field joined the FEA in denouncing the exemption as an unwarranted subsidy to small entitlements purchasers that would create economic distortions rather than aid the industry. ${ }^{182}$ Their criticisms fell on deaf ears; the amendinent passed both houses by large margins.

In the conference committee, however, opponents of the amendment fashioned a compromise provision that would allow the FEA to nullify the exemption by rule, subject to a one-house congressional veto. ${ }^{183}$ Shortly after the exemption took effect, the FEA proposed a rule to revoke it. 184 Evidence submitted during the rulemaking largely confirmed the FEA's view. Outlets of exempted small refiners were consistently undercutting the prices at other stations and increasing their market shares. Nonexempt refiners, especially those small refiners that sold entitlements and so were not eligible for the exemption, complained of competitive disadvantage. The exemption also was encouraging refiners to keep capacity and production at a level low enough to qualify for the exemption.

Because change in the exemption was subject to congressional veto, however, the FEA could not revoke it without nuollifying the small refiners. As a concession, the FEA increased the level of the small refiner bias, pointing not only to the congressional will embodied in the exemption but to the large number of small refiners now seeking

181. H.R. Rep. No. 340, 94th Cong., 1st. Sess. 47 (1975).

182. Interview with David Schooler, staff official for House Energy and Commerce Committee (June 7, 1982).

183. Energy Policy and Conservation Act, $\S 551,89$ Stat. 871,965 (1975)(amending $\S 4$ of EPAA)(codified at 42 U.S.C. $\$ 6421$ (1976).

184. See Energy Policy and Conservation Act, $\S 403,89$ Stat. 871, 948 (1975)(codified at 15 U.S.C. $\$ 753$ (1982)(creating the exemption); 41 Fed. Reg. 20,392 (May 18, 1976)(proposed rule revoking the exeinption). 
exceptions relief in the absence of the exemption, and to the strict standards for relief applied to entitlements sellers not eligible for Delta relief. ${ }^{185}$ This compromise sufficed. On May 27, 1976, the exemption expired. Although an increased small-refiner bias had been the FEA's most valuable bargaining chip, the availability of additional exceptions relief under the Delta standards played an important role in helping to appease the small-refiner lobby. In announcing that the exemption would expire, the FEA extended the period of the exceptions' effectiveness to six months. ${ }^{186}$ And as the new Beacon Oil Co. decision made clear, exceptions relief to any small refiner that apphied was now governed by the unequivocal rule promulgated in the 1975 Delta decision. ${ }^{187}$

A second congressional effort to influence the exceptions process concerned the exceptions office's procedures rather than its substantive policies. The Energy Conservation and Production Act (ECPA), enacted shortly after the Beacon decision, required the office, within ninety days of enactment, to "establish criteria and guidelines by which . . . special hardship, inequity, or unfair distribution of burdens shall be evaluated," and to then specify its criteria in each exceptions decision. ${ }^{188} \mathrm{Had}$ these requirements been in effect earlier, some of the office's important small-refiners decisions, such as its cryptic explanation of its method of calculating relief in cases like Mohawk, ${ }^{189}$ would have been called into question. But by the time the ECPA passed, the Delta standards for relief had already evolved into fairly clearcut rules and the new requirements had little effect on how the standards were applied.

The ECPA's other requirement-that the exceptions office publish criteria and guidelines for its decisions-appeared to call for the office to reevaluate and codify its standards. But the guidelines that it published sought only "to provide potential applicants with a general understanding of the grounds on which relief has been accorded to previous applicants."190 These guidelines explained the Delta standard

185. See 41 Fed. Reg. 20,392 (May 18, 1976).

186. Id. at 20,394 .

187. The only substantive development of the standard during the year and a half following Beacon Oil Co. was the explicit statement of the limitation of relief to the total amount of the refiner's entitlements purchase obligation, which the agency said had always been an implicit part of the standards for rehief. Another decision during this time described stringent standards for retroactive Della relief for a refiner that had revised its projections.

188. Energy Conservation and Production Act § 104, 90 Stat. 1125, 1128 (1976)(codified at 15 U.S.C. $\$ 766(b)$ (1982)).

189. See supra notes $157-59$ and accompanying text.

190. 41 Fed. Reg. 50,856 (Nov. 18, 1976). 
in a single sentence: "As set forth in the Delta Decision, the FEA will generally grant exception rehef to small refiners required to purchase entitlements so as to alleviate the adverse impact of the Entitlements Program which would otherwise prevent a firm froin achieving the lesser of its historical profit margin or return on invested capital."191 This brief statement, of course, excluded many elements of the standard. It failed to mention the seven-year test period, the kinds of relevant data, accounting requireinents, the duration of Delta exceptions, and the conditioning of relief on year-end review. The exceptions office thus managed to satisfy the statutory requirement, in form if not in substance, while retaining its freedom to modify crucial aspects of the standards in individual cases.

By the end of 1976, then, the energy agency had succeeded in deflecting even the most minimal congressional challenges both to the substantive small-refiner policy developed by the Delta-Beacon standard and to the exceptions office's sometimes erratic application of them. Until the motor gasoline crisis of 1979, the exceptions process in general, and its policy toward sinall refiners in particular, would remain essentially immune from congressional influence.

e. Efforts to curtail relief. As the price of entitlements rose and the proportion of price-controlled oil processed by refiners decreased in the late 1970's, the level of Delta-Beacon relief increased steadily. ${ }^{192}$ In part, this expansion reflected more permissive substantive standards for relief. Decisions seldom referred any longer to the "serious hardship" created by entitlements purchase obligations upon firms' competitive viability, originally a prerequisite for rehef. The Delta-Beacon criteria still purported to measure coinpetitive disadvantage, but the exceptions office granted extended relief to firms whose disadvantage could not have qualified them under the earlier standard. In addition, sinall refiners were given an incentive to design their financial statistics to justify greater relief. ${ }^{193}$ Indeed, as small refiners becaine more

191. Id. at 50,859 .

192. Delta-Beacon relief accounted for an estimated $\$ 300$ million of the $\$ 2$ billion transferred under the entitlements program annually by 1980 ; the number of refiners that lad received exceptions relief by the end of the program in 1981 totalled 36. Burt \& Watts-Fitzgerald, The Crude Oil Entitlements Program, in PeTroleum Regulation HaNdBooK, supra note 97, at 146, 155-56.

193. For example, the DOE found that some firms owning price-controlled oil liad entered into processing agreements under which other refiners processed the oil and enabled the owners to evade entitlements purcliase obligations. Other processing agreements routed controlled oil from refiners subject to the full entitlements obligation to refiners guaranteed lower processing costs because of Delta relief. Sinall refiners also sometimes purcliased and resold crude without processing it in order to establislı a higher base upon which to calculate their profit inargins. 42 Fed. Reg. 64,406 (Dec. 23, 1977). 
sophisticated in manipulatimg the standards, these practices spread. In late 1977, the ERA issued a notice (written at the OHA) asserting that small refiners had taken "unwarranted advantage" of the exceptions process and announcing immediate implementation of revised standards to deal with these and other abuses. ${ }^{194}$

These limitations on Delta-Beacon relief were the first of a series that the OHA was to adopt in an effort to prevent small refiners from using the program to gain competitive advantages. The OHA developed these refinements with a speed and flexibility far superior to the ERA's when the ERA acted in the same area. At no time, however, did the OHA's ad loc adjustments cause it to address more fundamental questions about its program, such as its distinction between entitleinents purchasers and sellers, the size of the subsidies it granted, and the economic distortions they generated.

Indeed, these changes created yet another problem: retroactivity. Two days before these first limitations were aimounced, the OHA adopted and applied them in four proposed exceptions decisions concerning relief for the October through Deceinber period. ${ }^{195}$ The OHA considered them prospective, because they extended to a period for which the OHA had not yet extended relief, due to the normal twomontli delay in the issuance of entitlements. The refiners, however, had already planned and largely implemented their operations for those months, raising a problem similar to the "retroactive recapture" that had arisen in connection with the 1975 year-end review. ${ }^{196}$ The courts and the FERC found the OHA's approach invalid. ${ }^{197}$

Such criticism reflected the growing implausibility of the OHA's perennial "emergency" justification. In its next set of Delta-Beacon changes, which began at the end of 1978, the OHA was more cautious im adjudicatory retroactivity. One change sought to eliminate the effect

194. Id.

195. Lunday-Thagard Oil Co., Proposed Decision and Order, Case No. DXE-0076 (Dec. 20, 1977); Young Ref. Corp., Proposed Decision and Order, Case No. DXE-0084 (Dec. 20, 1977); Kern County Ref., Inc., Proposed Decision and Order, Case No. DXE-0088 (Dec. 20, 1977); San Joaquin Ref. Co., Proposed Decision and Order, Case No. DXE-0095 (Dec. 20, 1977).

196. See supra note 178 and accompanying text. One firm, Lunday-Thagard Oil Company, even obtained a preliminary mjunction against application of the new limitations on the grounds that the revised standard was a new "rule, or an order having the effect of a rule" adopted in violation of the APA and the DOE Act requirements, and applied to the firm retroactively. Thagard Oil Co. v. Schlesinger, CV78-1159-11 (C.D. Cal. 1978), Transcript of Hearing, April 24, 1978, at 10, 19; see Proposed Order of Presiding Officer Affirming the Contested Decision and Order, Lunday-Thagard Oil Co., No. RA79-19, 10 Federal Energy Regulation Comm. (CCH) I 62,007 (Jan. 4, 1980).

197. Thagard Oil Co. v. Schlesinger, No. CV78-1159-11 (C.D. Cal. 1978), Transcript of Hearing, April 24, 1978, at 10, 19. 
of less profitable resale operations on firms' profit margims, the basis for calculating relief levels. ${ }^{198}$ Although this had been previously announced, its implementation was quite belated. A second, more farreaching change revised the 1975 ceiling on Delta-Beacon relief downward to reflect the substantial decline between 1975 and 1978 in the percentage of price-controlled crude being refined; retaining the old ceiling would therefore confer excessive benefits upon recipients of exceptions relief. ${ }^{199}$ This "Warrior adjustment" (named after the case in which it was formulated) amounted to an admission by the OHA that its standard had nurtured the continued and unjustified growth of Delta-Beacon relief. Moreover, it quickly becaine clear that the OHA's new adjustment formula was itself problematic. The OHA initiated an interlocutory proceeding to consider how best to revise the ceiling. Once agam dispensing with Federal Register notice, the OHA invited the eight firms that had filed objections to the original Warrior adjustment, as well as others that had participated im earlier exceptions cases under the program, to participate in a hearing, ${ }^{200}$ after which the OHA issued an interlocutory order adopting a new ceiling that became the basis for adjustments in other related cases. ${ }^{201}$

These refinements of the Delta-Beacon standards reflect both the strengths and weaknesses of the OHA's administration of the exceptions process. As OHA analysts became more experienced and sophisticated in discerning how the industry manipulated its standards, they could use the informal, case-by-case process to rectify these practices with relative ease. On the other hand, OHA policymaking was incremental and spasmodic, slowly evolving im response to particular criticisms or patterns im particular cases. This incremental policymaking is probably imevitable and perhaps even desirable. Still, abuses sometimes continued for months or even years after the need for change should have been apparent. In defense of the OHA, one must add, the ERA's record in reforming its rules in this area was far worse. For years, criticisin of the ERA-administered small-refiners bias had paralleled complaints about the OHA's Delta-Beacon standards, yet the ERA did not reduce the bias significantly until 1979. Even this cliange failed to eliminate the economic distortions created by the bias; the tiny, inefficient "teapot refineries" that the over-generous bias had

198. See, e.g., Warrior Asphalt Co., Proposed Decision and Order, Case No. DXE-1891 (Sept. 27, 1978), at 4.

199. Id.; see also Navajo Ref. Co., [3 DOE] ENergy MGMT. (CCH) I 81,141 (May 16, 1979).

200. See Warrior Asphalt Co., [3 DOE] ENERGY MGMT. (CCH) If 82,549, at 85,164 (Mar. 13, 1979).

201. Id. 
spawned continued to prosper throughout the period of controls.202 Moreover, the ERA's failure to devise a rule preventing the abuse of processing agreements was so abject that the OHA, despairing that the ERA would ever deal with the problem by rule, felt obliged to exclude processing agreements from the Delta-Beacon calculations. ${ }^{203}$

The OHA's most fundamental weakness, however, was its failure to reexamine systematically and thoroughly the basic policy assumptions undergirding the Delta-Beacon standards. For example, disparities in the cost of uncontrolled crude created financial problems for sellers of entitlements who were not covered by the OHA's standards as well as for buyers who were covered. The governing statute did not call for such a distmction and the ERA's rules generally avoided makmg it. The OHA did not closely analyze the broad implications of granting relief to one set of small refiners and denying it to others who may have been, on balance, similarly situated.204 Similarly, under the Delta-Beacon standards, the OHA allowed the "gross inequity" criterion to become so elastic that enornous subsidies were sometimes granted and continued without a convincing showing of "serious hardship" or economic justification. ${ }^{205}$

f. Conclusion. The evolution of the Delta-Beacon standards reveals soine important, more or less systematic theines surrounding the use of the exceptions process in energy regulation. First, the exceptions process functioned as an important palliative, complementing and sometimes substituting for a rulemaking process that could be (and in the energy agencies increasingly was) cumbersome and glacial. Through the OHA's adjudicatory forinat, a crucial subsidy program was estabhished swiftly and its standards were gradually and flexibly refined as patterns of abuse becaine evident. Second, an exceptions

202. See, e.g., Forecast for the Refining Industry-A 100\% Chance of Political Chaos, 12 NAT'L J. 597,599 (1980).

203. Interview with Doris Dewton, former ERA Deputy Administrator (June 29, 1982).

204. A few small entitlements sellers who could not obtain crude because of the cost disparity did receive exceptions relief under the stringent "serious hardship" standards. See, e.g., Asamera Oil (U.S.) Inc., Washington, D.C., Case No. BEL-1491, 6 DOE] ENERGY MGMT. (CCH) \81,311 (Oct. 16, 1980). Most sucl sellers, however, did not.

205. Only in the Little America Refining Co. case, in which the OHA found that the company lad used investments funded by Delta-Beacon relief to build itself into a dommant marketing force in its region, [3 DOE] ENERGY MGMT. (CCH) \ 81,012 (Jan. 12, 1979), and in a similar case, Charter Oil Co., [4 DOE] ENERgY MGMT. (CCH) 1] 81,080 (July 27, 1979), did the OHA completely terminate rehef to a firm that otherwise met the standard. Indeed, one such company received more than $\$ 100$ million in Delia-Beacon relief during 1978-1979 alone, telephonc interview with Joseph Bell, Dec. 17, 1983, while another received \$153 million in the period 1978-1980 and $\$ 6$ million more for the single month of January 1981, Husky Oil Co., Case No. BEX-0210 (May 11, 1981). 
process whose decisions would have far-reaching policy consequences had to find some way to elicit the broad participation and broadgauged policy analysis associated (in principle) with infornal ruleınak$\mathrm{mg}$ if those decisions were to be both legitimate and sound. In the Delta-Beacon program, the OHA managed to devise hybrid noticeand-comment procedures that soinetimes, although not always, fulfilled this need. Third, when an agency undertakes to develop and administer a complex, affirmative regulatory program through an exceptions process, it probably magnifies certain risks already inherent in that task: over-broad classifications, unrepresentative data, evasion by regulated firms, and unanticipated consequences. The OHA's development of the Delta-Beacon standards, piecemeal, ad hoc, and often reactive, realized all of these risks at one point or another.

Fourth, an exceptions process can be difficult for Congress and the courts to influence except at the level of the broadest and least effective kinds of procedural controls. In the case of the Delta-Beacon program, congressional reluctance to intervene in particular adjudications left the OHA with great autonomy. But even when Congress adopted a statutory mandate to articulate and codify its standards, the OHA easily deflected it. The courts, deferring to the OHA's expertise and emergency responsibilities, exercised only the most limited influence. Finally, the OHA's effort to use the exceptions process to develop broad policy through case-by-case adjudications, even when aided by wider participation, tends to foster a narrow, incremental perspective in which fundamental policy questions continue unaddressed for long periods of time, perhaps until after the policy lias become so well entrenched that those questions seem politically or programmatically irrelevant.

2. The Iranian Oil Embargo: The Union and Ashland Cases. During the nine months that followed the waning of the motor gasoline crisis in the fall of 1979, the OHA decided two extremely controversial exceptions cases: Union Oil $\mathrm{Co}^{206}$ and Ashland Oil Co. ${ }^{207}$ The enormous size of both companies involved, and the potential effects of the decisions on the industry and public, made the stakes unusually higli. Both cases posed an extremely difficult test for the integrity of the regulatory process at the DOE. Botli cases also reveal certain fundainental dilemmas inherent in the use of the exceptions process to formulate broad-gauged policy and to provide large-scale relief.

206. See Proposed Decision and Order, Union Oil Co. (Aug. 31, 1979), at 15.

207. See Transcript, In re Ashland Oil, No. BEE-0373, at 260-64 (Nov. 27, 1979). 
a. Union: The exception preempts the rule. Central to the issues in Union (and Ashland as well) was the sudden and pronounced disparity that appeared in 1979 between the world price of "contract" crude oil and the world price in the spot market. Prior to 1979, foreign crude had been readily available under contract and the spot markets for crude had been relatively small, and the spot market prices and contract prices tended to converge. The regulations had treated both categories of imported crude alike, lumping them together in an average price for all uncontrolled crude; with convergent spot market and contract prices, this treatment had no appreciable discrimmatory effect.

The Iranian revolution, which blocked crude exports to the United States and other western countries from Deceniber 26, 1978 through March 5, 1979, severed the close relationship between spot and contract prices. The mild shortage that developed, exacerbated by uncertainty as to when Iran would resune exports, encouraged aggressive bidding by firms and importing nations in the worldwide spot market. Some exporting countries deliberately cut back or terminated their contracts in order to sell their crude in the more profitable spot market. Spot nuarket prices escalated rapidly. ${ }^{208}$

The resulting price movements had a severe impact on Union Oil, a large integrated company. Union claimed to have lost 53,000 BPD of contract crude froin January through August 1979 due to Iranian cutbacks and reductions or cancellations of contracts by oil exporting nations and multinational oil companies. This loss forced Union into the spot nuarket to an inordinate extent. ${ }^{209}$ During the 22 weeks from April through August 1979, Union paid higher prices for foreign crude than any other American refiner for eight weeks, and paid one of the three highest prices for 14 weeks. As a result, Union's crude acquisition costs, which had averaged no inore than $\$ 0.29$ per barrel above the industry average for the years 1975-1978, climbed (after adjustments under the entitlements program) to $\$ 5.67$ per barrel (or over twenty percent) above the industry average by July 1979. For the third quarter

208. According to soine reports, the proportion of foreign crude that American firms purchased on the spot market increased from five percent of the total in 1978 to almost $15 \%$ in September 1979. By June 1979 , spot market prices had risen to $\$ 12$ to $\$ 18$ above contract prices posted by OPEC, depending on the grade and source of the crude; two months later, the spot market price remained as much as $\$ 12$ higher. Between the weeks of March 29 and July 12, 1979, for example, American refiners reported spot market prices chimbing $70 \%$, from as much as $\$ 22$ per barrel to a high of $\$ 38.50$. The average acquisition cost for domestic refiners (before entitlements prograin adjustinents) rose almost 50\% from $\$ 12.45$ per barrel in July 1978 to $\$ 18.58$ per barrel in July 1979. See Proposed Decision and Order, Union Oil Co. (Aug. 31, 1979) at 15.

209. The ratio of its spot market purchases to its total crude imports jumped from $16 \%$ to $62 \%$ between the first and third quarters of 1979 , although the industry average only rose from $5 \%$ to $15 \%$. 
of 1979, Union estimated that its retail gasoline prices averaged six cents per gallon higher than those charged by its competitors. ${ }^{210}$

Arguably, Union's injury was especially self-inflicted. First, it had adopted a long-term strategy of relying upon the spot market for its foreign crude suppties. Even before 1979, Union had relied on the spot market for 11 to 12 percent of its supply of crude oil, more than twice the industry average. This strategy had been based on two premises: stable market conditions and a spot market price that fell below the contract price for extended periods. 211

Second, Union's deinand for crude had been intensified by its high utilization of refining capacity. ${ }^{212}$ This higher utilization probably reflected its aggressive expansion, which substantially nicreased its share of the national gasoline market. ${ }^{213}$ Urion needed additional crude to retaim this larger market share. Any claim of "serious hardship" would be further undercut by its- fourteen percent increase in net profits between the third quarter of 1978 and the same period in 1979, producing a return that, although below that enjoyed by the largest American oil compamies, was substantial nonetheless. ${ }^{214}$

For these reasons, Union sought exceptions rehef by invoking the "gross inequity" and "unfair distribution of burdens" standards, which required it to show only that the regnlatory program burdened Union more than other similarly situated refiners. Union emphasized that the entitlements regulations both deprived it of benefits from its access to "old" crude and failed to take account of its unusually high cost of spot market foreign crude.215 Union's application alleged that its obligations to sell substantial volumes to other refiners under the buy-sell program further aggravated its cost disadvantage; it had to sell at contract prices despite its lack of immediate access to low-cost domestic crude. Union claimed that these regulations compelled it to choose between buying high-priced crude at a cost it could not pass through to its customers and curtailing its operations. If Union chose the latter, its

210. Application for Exception, Union Oil Co. (Aug. 31, 1979), at 15.

211. The strategy may also have been encouraged in early 1979 when DOE officials, fearful that the Iramian situation would produce a continued shortage of refined products, actually exhorted refiners to enter the spot market to replenish their supphes of crude. Proposed Decision and Order, Union Oil Co. at 13, 41.

212. For example, in July 1979, while the industry's average utikzation rate was $97.98 \%$, Union ran its refineries at $98.75 \%$. In August, when the national average dropped to $86.52 \%$, Union ran at $94.02 \%$.

213. Its share grew by an average of $18 \%$ from the first half of 1978 through the corresponding period in 1979, compared to an average increase of 5\% during the same period aniong the 21 largest integrated American refiners.

214. Proposed Decision and Order, Union Oil Co. at 40.

215. Union Oil, Application for Exception, at 1. 
customers would suffer either continued high retail prices or reduced supplies. Union therefore requested that the OHA grant sufficient relief from its entitlements obligations to bring its weighted average cost of imported crude into parity with that of the industry.

(i). The temporary exceptions proceeding. Along with its exception application, Union submitted an application for temporary relief. The company claimed that without such relief it must immediately decide whetler to charge noncompetitive prices or curtail production. A hearing was held within two weeks. As was typical in temporary exception proceedings, hittle advance notice was given. ${ }^{216}$ Nevertheless, eight of the other inajors appeared. Union had not expected this participation and was not fully prepared to counter their arguments. As a result, the opponents' presentations, rather than Union's relatively brief one, dominated the learing.

The opponents' mam argument was that Union's cost disadvantage resulted not from DOE regulations-a prerequisite for relief under the OHA's "gross inequity" standard-but fronı Union's own business decision to remain in the spot market im mid-1979 rather than to seek a new contract. Union responded that the regulatory system and crude markets were inextricably linked; any generally adverse effect should entitle a company to relief. The opponents also argued that Union's high utilization rate precluded a gross inequity im relation to other refiners, that the increase in foreign crude costs were not unique to Union, and that to subsidize its spot market purchases might encourage exporting countries to divert more of their crude from the contract market to the spot market. Union responded that absent emergency relief it would lower its utilization rate to below the national average, that its acquisition costs were far above average, and that a three-month grant of relief would liardly distort national economic policy. Union furtler suggested (somewliat vaguely) that relief could be structured to preserve the company's incentive to buy crude at the lowest possible price. ${ }^{217}$

Two hours after the hearing recessed, OHA Director Goldstein, the presiding officer, orally rendered his decision denying temporary relief. Because the average refinery utilization rate nationwide was only eighty-five percent, Goldstem found, Union's inability to operate at full capacity did not constitute a "gross mequity." Moreover, several

216. Three refiners served their opposing comments upon Union on the morning of the hearing, and Union did not serve the supplemental materials that the OHA had requested until later that day.

217. Transcript, In re Union Oil Co., No. DEE-5748 (Sept. 13, 1979). 
other firms had managed to absorb their higher than average crude costs without special relief.

Goldstein next turned to Union's argument that the consuming public would benefit if the OHA encouraged Union to acquire crude from the spot market. Union had submitted a handful of letters fron1 Union jobbers, and received support from the National Cooperative Refinery Association. Goldstein found that Union had failed to demonstrate any clear, specific harm to its customers, or any "acute" demand for the refined products that relief would enable Union to produce. On the other hand, lie took seriously the risks that relief to Union inight signal a willingness by the government to subsidize purchases of higli cost crude in the spot market on a large scale, perhaps diverting additional contract crude into the spot market. Goldstein called for further study of this problem. ${ }^{218}$

Goldstem's decision to deny temporary rehef, however, was only the end of the beginning of the Union case. For Union, the initial process provided valuable lessons about the substantive weaknesses of its claims and the metlods it had used to present them. With more tinie to prepare and witl this experience behind it, the company would eventually construct an effective claim for exceptions relief.

(ii). The choice of decision process. A recurrent issue throughout the entire Union proceeding was whether a DOE rulemaking or the exceptions process was the most appropriate method for addressing the problems caused by the disparity between contract and spot market crude prices. Indeed, of the three cases studied here, Union represents the DOE's most thorougl consideration of this issue, and the only instance in which the ERA and the OHA coordmated closely im resolving this fundamental issue. In Union, the preference for the exceptions process had a clear, articulated policy basis. By using the exceptions process as a safety valve to relieve pressure for a more comprehensive approach, the DOE could assist those refiners that suffered most from crude cost disparities while avoiding a new policy that could actually increase those disparities by encouraging use of the spot market.

The DOE began considering the clioice-of-process issue as early as the September 13 hearing on Union's request for temporary relief. Althougli some opponents had contended that Union's complaints could only be resolved through rulemaking, Union reasoned-and the OHA agreed - that the crude cost disparity problem was one that could be addressed through either rulemaking or the exceptions process, espe- 
cially as Union had carefully tailored its contentions to the contours of the OHA's "gross inequity" and "unfair distribution of burdens" standards. In his decision, Goldstein had stated that although rulemaking was "possible" and the exceptions proceeding "appropriate," both should not proceed at the same time. A conflict might arise over bureaucratic "turf" and an ongoing rulemaking proceeding could prejudice an exception proceeding. Goldstein therefore decided to inquire whether the ERA intended to institute a rulemaking directed at this problein "in an expeditious time fraine." 219 If not, he would continue to consider Union's application "on an expedited basis" by inviting public comments on it. ${ }^{220}$

On October 17, a Federal Register notice announced that although the "ERA has indicated that it is still considering this matter," the OHA would proceed with Union's exception application in view of the "urgency of Union's request."221 The OHA was clearly impatient and was atteinpting to force the ERA's hand. ${ }^{222}$ The OHA's notice also requested comments froin Union's customers and from all refiners under the entitleinents prograin on Union's application and on the more general issues raised by the high price of spot market crude, and announced that a public hearing would be held on Union's application. This unusual effort to broaden the scope of factfinding in an exceptions proceeding succeeded in éhiciting comments from nearly 700 parties, including refiners and a large proportion of Union's jobbers, dealers, and customers. Several days after the OHA's action, the ERA announced that it had decided not to initiate a ruleniaking yet, and expressed the now-familiar fear that a subsidy would encourage increases in both spot and contract market prices. ${ }^{223}$

The OHA proceeded with a second hearing in the Union case on October 30. Despite the flood of comments received and despite evidence of large and widespread disparities between different refiners in post-entitleinent crude costs, ${ }^{224}$ the OHA focused narrowly upon Union's particular problems. At no time did the OHA directly address the question of how inany firms were in Union's position due to spot

219. Id. at 91 .

220. Transcript, In re Union Oil Co., No. DEE-5748 (Sept. 13, 1979).

221. 44 Fed. Reg. 59,932 (Oct. 17, 1979).

222. This attitude would become even more evident in the Ashland and Ohio Independents cases. See infra notes 233-67 and accompanying text.

223. Memorandun from Douglas G. Robinson, ERA Deputy Administrator (Oct. 15, 1979).

224. Indeed, these disparities were larger than those that existed in 1974 when the entitlements program itself was created. See Draft Regulatory Analysis, Modification of the Entitlements Program to Reduce Differences in Domestic Crude Costs, Docket No. ERA-R-80-36, October 24, 1980. 
market price movements. Thus, the exceptions process never addressed, much less resolved, the initial issues that a rulemaking proceeding would have addressed: precisely what the problem was, how widespread and severe it was im the industry as a whole, and how it might best be remedied.

Although the ERA had mdicated that it might initiate a rulemaking once the OHA had passed on the exception apphication, it never did so. When the OHA granted permanent relief to Union and extended the possibility of such relief to others disadvantaged by high spot market-related crude costs, it relieved the pressure on the ERA to change the regulations. The OHA also avoided the demand for the larger, more broadly conferred subsidy that the ERA thought desirable, while giving hope that the worst cases (like Union) would be remedied.

(iii). The award of relief to Union. Two months after the second hearing on Union's application, the OHA issued a proposed and interim order grantimg relief. The OHA's turnabout probably reflected several factors. First, Union's jobbers and custoniers had presented evidence that they were being harmed by the high crude costs facing Union. ${ }^{225}$ Second, Goldstem had devised a more acceptable form of relief; mstead of granting additional entitlements, the OHA would simply require certam large producers to supply Union with crude at contract-level prices. By stepping up production or rearranging their previous contracts, these companies could nore readily obtain the crude without paymg the higher spot inarket prices. Requiring them to sell to Union at below-spot market prices would encourage them to avoid the spot market, and could thus prove less inflationary than a direct subsidy to Union through the entitlements program.226 The OHA's proposed decision, issued December 21, 1979, adopted this remedial approach after finding an "unfair and disproportionate burden" for Umion and "serious financial difficulties" for its marketers. ${ }^{227}$ The OHA pointed to Umion's relatively high crude acquisition costs and, even after discountimg for Union's higher-than-average utilization rate, attributed Union's predicament not only to its own business strategy

225. One survey estimated a decline in gasoline sales by Union's jobbers five times greater than the national average. See Transcript, In re Union Oil Co., Case No. DEE-5748, at 111 (Oct. 29, 1979).

226. Goldstein first suggested this possibility in the opening minutes of the October 30 hearing. In re Union Oil Co., No. DEE-5748, at 34-35 (transcript of hearing, Oct. 29, 1979). When Union's counsel readily agreed that its application could be construed to request just such a rentedy, Goldstem advised Union to file a further submission that would elaborate how the directed sales might work. Id. at 41 . On November 16, Union did so. See Second Set of Supplementary Comments of Umion Oil Co., In re Union Oil Co., No. DEE-5748 (Nov. 16, 1979).

227. In re Union Oil Co., No. DEE-5748, at 42 (Proposed Decision and Order, Dec. 21, 1979). 
but to the entitlements and buy-sell programs as well. The OHA concluded that the majors had failed to demonstrate that Union had deliberately rejected opportunities for contracts or that its competitors had borne equally heavy regulatory burdens. Moreover, the regulatory programs had adversely affected Union to a far greater degree than other similarly situated firms.

The OHA's remedy directed certain large refiners to make sales of crude to Union. ${ }^{228}$ This remedy closely resembled the temporary relief the OHA liad fashioned for Ashland Oil Company only a montl earher. ${ }^{229}$ To alleviate the hardship to Union's marketers, the OHA required Union to operate its refineries at no less than the industry's projected average utilization rate; thus, Union could no longer profit by lowering its utilization rate. Union was further required to lower its motor gasoline and heating oil prices one cent per gallon and maintain those lower prices for inost of the period of relief. The OHA also prohibited Union from using special DOE "tilt" regulations; these would have allowed Union to allocate its crude cost increases disproportionately to its motor gasoline. Finally, an "interim" order provided for immediate implementation of relief. ${ }^{230}$ The OHA did not issue a final decision in the case, however, for another two years. ${ }^{231}$ When it did issue a decision, the OHA upheld the earlier order on every point. ${ }^{232}$

b. Ashland: The exception precludes the rule. On Noveniber 12, 1979, shortly after American diplonats were taken hostage in Telie-

228. Rather than selecting the nine firms with domestic refining capacity of 500,000 BPD or more to supply Union, as in $A$ shland, the OHA selected the 15 refiners with domestic capacity of 200,000 BPD or more. This would lessen the burdens placed upon those nine refiners already designated to supply Ashland. The OHA calculated the share to be supplied by each refiner through a coinplex weighting of five indices that neasured refinery runs, refinery utilization, worldwide production, average cost of imported crude, and overall adjustcd cost of crude acquisition. The total amount of crude to be supplied to Union was 75,046 BPD in December; 70,881 BPD in January; and 58,560 BPD in February. Following a hearing January 22, 1980, the OHA extended the relief into February, despite a reduced disparity between spot market and contract prices.

229. See infra note 243 and accompanying text. Union was not to pay nore than the supplying refiner's average costs of imported crude for November and December, plus an increment of $\$ 1.50$ per barrel.

230. See In re Union Oil Co., No. DEE-5748, at 15 (Proposed Decision and Order, Dec. 21, 1979).

231. A primcipal reason for the delay was that some of Union's new suppliers had sought to conduct extensive discovery, even up to the date of the Final Decision and Order.

232. See In re Union Oil Co., No. BEA-0641, [10 DOE] ENERGY MGMT. (CCH) If 80,104. As we shall see, this was in striking contrast to the $A$ shland case in which several subsequent decisions reduced the rehief thc OHA had initially granted. This contrast may reflect the OHA's greater care and detiberateness in rendering the proposed decision in Union than in its initial decision in Ashland. See infra notes 241-42. 
ran, President Carter issued a proclamation halting United States imports of any Iranian crude not already loaded on tankers. Contracts between Iran and nineteen American companies, including Ashland Oil Company, were instantaneously aborted. Ashland, one of the largest independent refiners with a capacity approaching 400,000 BPD, had sold off its production operations during the early days of controls. ${ }^{233}$ Suddenly forced to replace Iranian crude in the spot market, Ashland and the other companies faced a disparity in acquisition costs similar to Union's, as spot market prices had now risen to above forty dollars per barrel. Ashland's lost contracts for Iranian oil at approximately twenty-three dollars per barrel had supplied about a quarter of the crude it refined and, according to Ashland, could only be replaced in the spot market. Because Ashland's prices for refined products were already among the industry's highest, Ashland claimed that it could not pass the still higher costs of crude from spot market purchases through to its customers. Like Union, Ashland predicted that it would be forced to reduce its refinery runs unless the OHA granted immediate relief.

On November 20, representatives of Ashland and other companies met with DOE Secretary Duncan to discuss appropriate regulatory responses to the presidential proclamation. ${ }^{234}$ Along with other firms, Ashland recommended that the ERA immediately reinstitute the broad pre-1977 buy-sell prograin, which redistributed supplies of crude among all refiners. Ashland argued for an emergency rulemaking extending the program's benefits to all refiners that had lost Iranian contracts. The ERA appeared to agree with Ashland's suggestion when, on November 23, it proposed three alternative plans for adapting the buy-sell program to the Iranian problem: hberalizing the current program to benefit large refiners like Ashland; establishing a special buysell program to aid the large independents; or replacing the current program with a comprehensive allocation program among refiners. ${ }^{235}$

The ERA did not, however, share Ashland's sense of urgency. The ERA did not eliminate the prior comment period, as Ashland had urged, but simply shortened it from the usual 60 days to 30 days. The ERA reasoned that the two months needed for the last Iranian ship-

233. See OIL \& GAS J., March 12, 1979, at 27; Interview with Hazel Rollins, former ERA Administrator (July 21, 1982).

234. A week earlier, on the day following the proclamation, Ashland had discussed this subject informally with the ERA. Transcript, In re Ashland Oil Co. Nos. BEE-0373, BEL-0373, BSG-0007, at 76 (Nov. 26, 1979).

235. In 1977, the DOE had revised the program, liniting its benefits to small refiners without ready access to foreign or domestic crude. Under these revisions, neither Ashland nor 13 of the 18 other deprived refiners was eligible to receive additional supphes to replace their Iranian crude. 
ment to reach the United States would prevent any hardship before January 1, 1980. Fearing that the rulemaking night be a dead end and that bureaucratic delays might impede full implementation of any rule promulgated on January 1, Ashland decided to apply simultaneously to the OHA for immediate rehef.

An Ashland representative telephoned Goldstein and arranged a "procedural conference" on November 19 to discuss the form that Ashland's apphication for relief should take. ${ }^{236}$ At this conference, the procedures the OHA intended to use to deal with Ashland's exception application took shape. Ashland's application, not surprisingly, resembled the apphication that Union had already put before the OHA two months before, which would likely be approved soon. ${ }^{237}$ Because Ashland was far from being in danger of gomg out of business, it followed Union's lead and invoked the "gross inequity" and "unfair distribution of burdens" criteria rather than "serious hardship." Ashland predicted harm fronl cutbacks in refinery production both to its distributors and to the regions of the country, chiefly Minnesota and the Kentucky area, where its activities were concentrated.238

As in Union, the major refiners opposed exceptions relief to Ashland on the ground that a rulemaking was the appropriate means to address the problem. Here, they argued, the rulemaking was already under way. Goldstein, however, did not defer to the ERA and the rulemaking process as he had when rejectimg Union's application for temporary relief. Instead, when he almounced the decision granting temporary relief at the conclusion of the November 27 hearing, Goldstein simply noted that the outcome of the ERA's rulemaking remained uncertam, and might prove inadequate to meet Ashland's urgent

236. The only communication between the OHA and the ERA on the subject was a telephone call from an assistant to ERA Administrator David Bardin to OHA Director Goldstein informing the OHA of Ashland's intention to apply for relief.

237. The OHA later described what transpired at the November 19 procedural conference:

Ashland advised the OHA that it intended to file a request for relief and requested advice as to the nature of the filing. The Director of the OHA suggested that the exceptions process was the procedural framework that was most appropriate and suggested the supporting data he thought would be necessary to respond to likely questions arising from the Ashland application. In addition, the Director and Ashland discussed the proper parties to be served, and agreed on a date for a hearing.

Transcript, In re Ashland Oil Co., No. BEE-0373 at 260-64 (Nov. 27, 1979). In retrospect, Goldstein beheved that representatives of opposing interests probably should have been invited to attend that conference. Telephone interview with Melvin Goldstein (December 30, 1982).

238. At the same time, Ashland also applied for "special redress" relief because it had been excluded illegally from regulatory benefits from the buy-sell program and other DOE programs. This part of the application would be dismissed when the OHA granted exception relief to the company. 
needs. ${ }^{239}$ Here, as in Union, reliance upon the exceptions process amounted to a decision not to address the more general problem.

In preparing its case, Ashland had profited from Union's recent experience and from the informal procedural conference with Goldstein. Ashland presented fifteen witnesses, including company officials, several independent gasoline inarketers supplied by Ashland, representatives from airlines, two railroads, and utilities that Ashland served, and state officials from Kentucky, West Virginia, Ohio, and Minnesota, all areas served by Ashland. Statements by Senator Wendell Ford of Kentucky and Congressinan Nick Rahall of West Virginia rounded out Ashland's affirmative case. Reports also circulated that Ashland had used its Minnesota connections to enlist Vice President Mondale, a former Senator from that state, to express support for its application.

In view of Goldstein's determination to press the hearing to an early conclusion and decision, Ashland's extensive presentation preeinpted much give-and-take in the hearing itself, leaving httle time for the opposing arguments of the eight majors that sent representatives. ${ }^{240}$ Besides citing the ERA's pending rulemaking, the majors argued, as they had in Union, that Ashland's dependence on Iranian crude was caused by its discretionary business decisions, not by the regulatory program. They also argued that Ashland's present difficulty resulted from a presidential action not subject to the DOE exceptions process, and that immediate relief was unnecessary because Ashland's last supplies from Iran would not be exhausted until January 1.

Announcing his decision at the conclusion of the hearing on November 27, Goldstein rejected eacli of Ashland's opponents' conten-

239. Transcript, In re Ashland Oil Co., No. BEE-0373, at 234 (Nov. 27, 1979). Goldstein's decision was not subject to Administrative Review Committee jurisdiction. Grants of temporary exceptions are within the discretion of the OHA itself. See supra text accompanying note 136. His disregard for rulemaking caused much dismay within the DOE. His prediction was vindicatcd, however, when the Departinent concluded that the Iranian situation did not justify a regulatory change and abandoned the rulemaking. See Interview with Douglas Robinson, former ERA Deputy Adıninistrator (May 20, 1982). As Goldstein had anticipated, new DOE regulations would not be welcoined by a President entering an election year on a platform of deregulation. Moreover, the OHA's action doubtless strengthened the case for aborting the rulemaking, for the OHA had relieved the pressure for regulatory change from one of the most vocal and influential coinpanies. Thirteen refiners, including Ashland, had lost Iranian crude and remained ineligible for buy-sell program relief. See Kerr-McGee Corp., [4 DOE] EnERgY MGMT. (CCH) I 81, 252 (Dec. 21, 1979). Still, the buy-sell program amendment that Ashland initially sought froin the ERA might have alleviated hardships suffered by the other twelve refiners, hardships that could have been significant while not bemg severe enough to justify exceptions relief. This might have saved Ashland, the DOE, and the other parties to the Ashland cases the years of litigation and uncertainty that were to follow.

240. See infra notes $375-77$ and accompanying text. 
tions. ${ }^{241} \mathrm{He}$ found that Ashland had met the necessary criteria for temporary exception relief, and he granted relief to last three months. ${ }^{242}$ As in Union, the OHA required Ashland to maintain both historical production levels and certain allocation fractions for gasoline and other refined products during the relief period. The OHA assigned nine refiners with refining capacity exceeding 500,000 BPD to supply Ashland, at prescribed volumes and prices. ${ }^{243}$

Marathon Oil and several other mandated suppliers immediately challenged the OHA's action in court. They contended that the OHA's procedures-the ex parte conference between Ashland and Goldstein; the inadequate notice before the hearing; the lack of prior notice of confidential materials discussed in a closed hearing session; Goldstein's curtailment of questioning and of testimony opposing relief; and lack of prior notice of the OHA's criteria for selecting Ashland's suppliersviolated due process. The district court, denying Marathon's request for a preliminary injunction, upheld the OHA's procedures, but only "in view of the patent einergency to which the OHA proceeding was addressed" and the "relatively limited duration [of the] order issued by that body."244 Stressing that its decision "should not be regarded as an endorseinent of possible OHA action on a longer-tern basis with more lasting policy implications," the court warned that "when the exception becomes the rule, rulemaking is the appropriate method-with all of the procedural safeguards attendant thereto-by which the Department of Energy would generally have to proceed."245

241. Statement of Chairman Goldstein, Transcript, In re Ashland Oil Co., No. BEE-0373, (Nov. 27, 1979). First, several firms had conceded that Ashland's decision to contract with Iran was not imprudent when made in the summer of 1979. Id. at 250. Second, Goldstein stressed the "interrelationship of energy decisions made by the executive branch of government, and the impact on firms of those actions when filtered through the various DOE regulatory programs," citing OHA cases that granted exceptions relief in connection with executive branch efforts to strengthen the Puerto Rican economy. Id. at 237. Finally, Goldstein held that Ashland could not prudently contimue at existing refining levels if it faced sharp curtailments after January 1. Id. at 248.

242. Id. at $236-49$.

243. Id. at 253-57. One of these refiners, Gulf Oil Corporation, apparently received no notice of the hearing, much less of the order requiring it to supply Ashland with 9440 barrels of crude per day for three months, until after the hearing had been held and the order issued. See Exhibit I to letter dated July 5, 1983 to William C. Bush, Administrative Conference of the United States, from Edward T. Cotham, Jr., The Gulf Companies.

244. Marathon OiI Co. v. DOE, 482 F. Supp. 651,658 (D.D.C. 1979).

245. Id. On July 14, 1980, the court granted summary judgment to the DOE, holding that the OHA's decision was rational and supported by substantial evidence, and that the ex parte communications between the OHA and Ashland did not prejudice the mandated suppliers. On appeal, the TECA ruled that because a final decision in the case was still pending, the temporary exception was not ripe for review. Eight of the nine mandated-suppliers settled with Ashland and the OHA. Marathon's challenge is still pending. See Ashland Oil Co., Gulf Oil Corp., [9 DOE] ENERGY MGMT. (CCH) I 81,058 (July 19, 1982). 
Although the court did not condemn the merits of the Ashland decision, the OHA cast doubt upon the wisdom of its earlier order by substantially reducing the level of relief on no less than three occasions over two and one half years, ultimately by more than 35 percent. ${ }^{246}$ The long delay in issuing a final decision reflected intense controversy within the DOE about the excessive relief Ashland had received. The OHA found that Ashland should have been granted only half of the already twice-reduced allocation of 55,000 BPD that it received in February 1980. But ordering Ashland to return the excess crude to its suppliers in 1982, a time of glut in world crude inarkets, would hardly compensate them. The OHA therefore ordered restitution of almost six million dollars, the total of the profits that each supplier had lost from having to supply Ashland the excess relief. Appeals of this order to the FERC and the courts will continue for years. ${ }^{247}$

Ashland reveals certam flaws that seem inherent in an exceptions process that grants massive relief swiftly after summary, informal procedures in the face of a perceived einergency. Rapidly changing market conditions, probably unforeseeable at the time, undermined the OHA's basic assuinptions. Ashland's claims, which of course emphasized the magnitude and persistence of its distress, could only be clearly confirmed or refuted well after the fact. Yet relief, once granted, could not readily be withdrawn. Those companies that the OHA had compelled to provide the rehief could not easily be made whole when the error was finally discovered years later. In a complex industry witl rapidly changing inarket conditions, the status quo ante is difficult to discern, much less to recreate. Huge investments may have been made on the basis of the earlier grant of relief. Relief-related price changes may have already been passed through to customers and ultimately to consumers, affecting their economic decisions in complicated ways. In

246. On January 23, 1980, the OHA ordered that the sales it had directed to Ashland be reduced by 25\% (to 60,000 BPD). Ashland Oil, Inc., [5 DOE] ENERGY MGMT. I 82,513 at 85,035 (Jan. 23, 1980). It now appeared that some of Ashland's problems would have occurred regardless of the President's action, and that the competitive situations of Ashland and its customers were not nearly as disparate as had been predicted. Id. at 85,034 . The OHA ordered a second reduction in the volume of directed sales to Ashland on February 11, 1980, when the assumptions underlying the January order appeared to be wrong. Ashland Oil, Inc., [5 DOE] ENERGY MGMT. (CCH) I 82,523 , at 85,101-02 (Feb. 11, 1980). The third reduction did not occur until two and one half years later, when the OHA issued its final decision in the case. Ashland Oil Co., Gulf Oil Corp., [ 9 DOE] ENERGY MGMT. (CCH) If 81,058 (July 19, 1982). During the relief period, the disparity between the spot market and Iranian contract prices, as well as Ashland's dependency on that market, had declimed dramatically; indeed, in February 1980 Ashland supplied its customers with 4 percent more of their base period allocations than the OHA's order required. Id. at 82,839.

247. Interview with Fred Drogula, Counsel to Ashland Oil (June 2, 1982); see, e.g., Ashland Oil Co., [10 DOE] ENERGY MGMT. (CCH) \82,524 (Oct. 28, 1982)(partially granted applications for modification of exceptions decision). 
these and many other ways, these remedial eggs are especially difficult to unscramble.

Although the ERA dropped its rulemaking proceeding once the OHA had granted relief, it may be that the problems that $A$ shland posed for the exceptions process would have been better addressed by the ERA through rulemaking. Perhaps the problems were generic in nature, demanding a more compreliensive analysis and solution than an exception process focused upon individual cases (and atypical ones at that) can furnish. There are reasons, however, to doubt this. Of the firms that had contracts with Iran, only Ashland and one other company applied for exceptions relief, and only Ashland met the standards for relief. Moreover, relief had to be granted almost at once if it were to be effective, yet the ERA's ability to promulgate sound rules quickly was notoriously limited. Thus, the OHA's willingness and ability to act swiftly and decisively, later adjusting its remedy in light of new evidence and changing conditions, must be applauded. Even if the specific relief the OHA granted seemed excessive (at least in hindsight), its flexibility and responsiveness were essential.

3. Pricing Alaskan North Slope crude oil-The Ohio Independents: the exception provokes the rule. More so than in Union or Ash. land, DOE regulations directly caused the difficulties for which Ohio Independents for Survival (OIS) sought exceptions relief. In 1977, the DOE decided to subsidize Alaska North Slope (ANS) crude through the entitlements program, as it had subsidized production of several other special categories of oil. The DOE had previously treated ANS crude, like other new domestic production, as "upper tier" controlled oil under the allocation and pricing regulations. Under the ERA's new rules, ANS crude's price status would contimue, but the DOE would treat it as imported crude for entitlements program purposes. By earning entitlements rather than having to purchase them, refiners of ANS crude (who were also ANS producers) would enjoy a subsidy similar to that of small refiners under the small-refiners bias. According to the DOE, this subsidy was necessary to compensate for the high cost of transporting ANS crude from Alaska, because producers could not recover that cost under the pricing regulations. ${ }^{248}$

This change brought the after-entitlements price of ANS crude roughly in lime with the price of imported and other uncontrolled oil. But when world spot market prices rose above forty dollars per barrel in 1979, imflating domestic uncontrolled prices as well, the new rule

248. 42 Fed. Reg. 41,565 (Aug. 17, 1977). 
distorted these relationships. The price of "new" oil soared, yet the regulations limited price increases for ANS crude; by January 1980, the total after-entitlements cost to refiners of ANS crude, including transportation cost, was nearly ten dollars per barrel below that of domestic uncontrolled crude. ${ }^{249}$

Three large refiner-producers-Sohio, Arco, and Chevron-controlled 94 percent of all ANS crude. DOE pricing regulations required these compaines to reffect their lower crude costs in lower product prices. They were therefore obliged to price their refined products well below other firms' prices. Indeed, Sohio, which refines and markets most of its products in Ohio and was the unost geographically concentrated of the three companies, was charging ten to twelve cents per gallon less at the gasoline pump than its competitors. As a result, Sohio's gasoline sales increased by about 25 percent between early 1979 and early 1980, despite Ohio's declining demand overall. 250 Sohio's lower prices severely undercut the independent marketers that comprised the OIS, whose 94 members sold inost of the refined products independently marketed in Ohio.

In Ohio Independents for Survival, ${ }^{251}$ OIS petitioned the OHA to order the ERA to develop a rule remedying Sohio's regulatory windfall. Subsequently, OIS urged that the OHA, which disavowed any authority to issue such an order, itself eliminate the entitlements benefits for the ANS crude through a special redress order. At the April 8 hearing, Goldstein opined that "the economic viability of Ohio independent distributors is in very serious jeopardy" because of Sohio's subsidy, but he declined on two grounds to order the relief OIS requested.252 First, the OHA could not compel the ERA to initiate a rulemaking. Second, Sohio had not received adequate notice of the specific relief urged by OIS. Instead, Goldstein would forward the hearing transcript and relevant documents to the ERA, emphasizing the "very urgent situa-

249. ANS crude, then 9 percent of refinery purchases, cost $\$ 304$ million less in January 1980 than the same volume of crude purchased at average cost. Economic Regulatory Administration, Draft Regulatory Analysis: Modification of Entitlement Treatment of Controlled Alaska North Slope Crude Oil, May 7, 1980, at 4.

250. In re Ohio Independents for Survival, No. DOE/BEE-1075, at 151 (April 30, 1980)(transcript of proceedings) [heremafter cited as Ohio Independents Transcript].

Forty-four inembers reported that average sales in March 1980 dcclined 30 percent below March 1979 levels. Reduced market shares and serious financial difficulties squeezed their profit margins substantially. See Statement of Chairman Goldstem, Ohio Independents Transcript, supra note 250 , at $152-53$.

251. No. BEL-1075 (May 1, 1980), rescinded, No. BEX-0055 (May 5, 1980).

252. See Statement of Chairman Goldstein, In re Ohio Independents for Survival, No. BSG0018, at 157, 158-59 (transcript) (April 8, 1980). 
tion."253 Goldstein suggested three forms of possible relief, inviting OIS to apply for a temporary exception because it was the only avenue of rehef that did not require that the rest of the Department concur. ${ }^{254}$ A week later, OIS did so, urging that Sohio be required to pay into the entitlements fund an additional four dollars per barrel of ANS crude, and then to reflect this additional cost in higher product prices. OIS also requested the OHA to make regulatory adjustments further raising Sohio's prices, and to lower the amount of product that Sohio's dealers were distributing. 255

An April 30 hearing added httle new evidence to the record of the previous hearing. Sohio, unable to show that independent marketers had not been victimized by its subsidized pricing, emphasized that its lower prices benefitted Ohio consumers. Sohio also questioned the OHA's authority to grant relief extending beyond OIS members. Finally, it maintained that the ERA's impending rulemaking made exceptions relief inappropriate.

Like the issues presented in Ashland and Union, the problem posed by subsidizing ANS crude affected more than the individual exceptions applicant. Also, as in Ashland and Union, this exception proceeding concerned only the most pressing instance of the problein, reflecting the concentration of Sohio's marketing operations in the Ohio area. In the temporary exception hearing, an attorney for OIS quoted a stateinent by the ERA Administrator that a rulemaking notice to address the problem would appear within a week. ${ }^{256}$ Doubting that the ERA would act, ${ }^{257}$ Goldstem conducted the exception proceeding without any material contribution by the ERA. 258

Goldstein's decision at the conclusion of the hearing brushed all objections aside. Abandoning any pretense of deference to the prospect of ERA rulemaking, lie held that exceptions relief was appropriate whenever the OHA's standards were met and relief through a rulemaking was uncertain or might not occur quickly enough. Indeed, quoting froun the proposed decision in Ashland, Goldstem argued that the OHA

253. Id. at 160 .

254. The first was the removal of ANS crude from Sohio's entitlements credits; the second, "that Sohio be required to buy entitlements of a certain dollar value"; the third, "that Sohio be required to sell products to certain Ohio Independents." Id. at 161-62.

255. Ohio Independents Transcript, supra note 250, at 4.

256. See Statement of William H. Bode, Ohio Independents Transcript, supra note 250, at 115. The lawyers for OIS quoted the ERA Administrator as saying she supported exception rehef despite the pending rulemaking, $i d$, but even if she had called Goldstem to tell him this, as they claimed she had promised to do, no inechanisin existed to resolve how the rulemaking and the grant of exception relief would imteract.

257. Telephone interview with Melvin Goldstein (December 30, 1982).

258. Interview with Melvin Goldstem, former OHA Director (June 3, 1982). 
was actually compelled to grant relief unless a final rule was imminent, regardless of whether a rulemaking was pending or whether a rule would be preferable. 259

Although the question of remedy had received little consideration at the hearing, the OHA's solution differed significantly from even the innovative remedy it had prompted OIS to request. Instead of basing Sohio's new entitlements purchase obligation im its total refinery production, as OIS had urged, Goldstem based it on the price differential on Sohio's refined products in Ohio multiplied by its gasoline sales in Ohio, a total of over fourteen million dollars. Sohio could recover this cost only by increasing its retail gasoline prices in Ohio. As if granting relief to OIS by requiring Sohio to buy entitlements were not unusual enough, Goldstein concluded that if Sohio's additional entitlement purchases went into the pool of entitlenents funds and ultimately contributed to lower net crude costs and gasoline prices for all refiners, the refiners would use the savings to decrease their banked costs ${ }^{260}$ rather than to lower their prices. To avoid this, the fourteen million dollar payment would be entered as a separate line item in the entitlements hist, and the money placed in an escrow account in the Umited States Treasury. The OHA's order purported to give the ERA discretion to "take into account" the fourteen million dollars in "any rulemaking proceeding which it may conduct" with respect to the ANS crude, and authority to dispose of the funds in the course of such a rulemaking. If no ANS ruleinaking occurred, the OHA could, "in its discretion," transfer the escrowed funds to unrestricted Treasury accounts or "conduct further proceedings" concerning the disposition of the funds. ${ }^{261}$

Goldstein's decision, althougl characteristically creative, left open some crucial legal and policy questions, such as what the ERA or the OHA should do with the fourtcen million dollars and how to integrate

259. In contrast to the rulemaking authority of the ERA, the adjudicatory authority of OHA is nondiscretionary. The DOE Organization Act requires OHA to entertain applications for exception and, if the applicant makes a showing that a DOE rule or requirement is causimg it to incur a serious hardship, gross inequity or unfair distribution of burdens, appropriate exception relief nust be granted.

Ohio Independents Transcript, supra note 250 , at 147 . This argument was perhaps disingenuous in hight of his own encouragement to OIS to apply for exception relief and the reality of the OHA's broad discretion over whether, in what form, and in what amount relief should be given. In fact, Goldstein believed that any ERA rulemaking would have been too protracted to be useful. Telephone interview with Melvin Goldstein (Deceinber 30, 1982).

260. Refiner pricing regulations allowed these companies to "bank" or carry forward increased costs incurred in a given month of measurement and not recovered during that month. 10 C.F.R. § 212.83(e) (1981).

261. Ohio Independents for Survival, [S DOE] ENERGY MGMr. (CCH) I 81,306, at 83,327 (Case No. BEL-1075)(April 30, 1980), decision and order rescinded, [5 DOE] ENERGY MGMr. (CCH) I 82,555 (Case No. BEX-0055)(May 5, 1980). 
the OHA's regulation of Sohio's marketing operations in Ohio into the rules that the ERA was presurnably about to develop. The decision, which threatened to preempt ERA's authority, just as Ashland had, was extremely controversial, and inany believed that its main purpose was to goad the ERA imto developing a new policy on ANS crude. ${ }^{262}$ On May 5, 1980, four days after the original decision, Goldstein rescinded it, "pursuant to a determination of the Deputy Secretary" of the DOE. ${ }^{263}$

Two days later, the ERA issued its "regulatory analysis," a detailed consideration of the alternative regulatory remedics for the problein of ANS crude, ${ }^{264}$ and the next day published a proposed rule. In contrast to the exception proceeding, participation in this rulemaking process was extremely broad, with testimony and written comments from representatives of all segments of the petroleum industry, including producers, refiners, marketers, and farmers' energy cooperatives, as well as the United States"Department of Justice, the Federal Trade Commission, United States congressinen and senators, and officials representing Ohio, Alaska, New York, Massachusetts, Cahfornia, and the City of Los Angeles. ${ }^{265}$ Within two inonths, the ERA announced a final rule treating ANS crude as a separate category for entitlements prograin purposcs, ${ }^{266}$ eliminating almost all of the problem. ${ }^{267}$

The Union, Ashland, and Ohio Independents cases afford different perspectives on the strengths and limitations of the exceptions process admimistered by the OHA. In each case, the OHA moved decisively to fill a reinedial void created by the ERA's institutional paralysis and to meet an apparently urgent and immediate need until more systenatic

262. Ohio's congressional delegation was astonished that the DOE would mandate a large increase im gasoline prices to Ohio consumers. The White House, fearful of the political effects of a well-publicized price increase on the impending Ohio presidential primary, expressed concern to the Deputy Secretary, Joln Sawhill, who directed Goldstein to withdraw the decision. Goldstein later conceded that he "might have overreached." Interview with Melvim Goldstcin, supra note 258; telephone interview with Melvin Goldstem (December 30, 1982).

263. Supplemental Order, Ohio Independents for Survival, [5 DOE] ENERGY MGMT. (CCH) I 82,555 (Case No. BEX-0055) (May 5, 1980). The decision left no doubt in anyone's mind about what had transpired.

264. See Robinson, supra note 223. Sawhill may have directed the ERA to complete its analysis and proposed rule on an accelerated basis. Telephone interview with Melvin Goldstein (December 30, 1982).

265. See Final Rule, Alaska North Slope Crude Oil Entitlements, 45 Fed. Reg. 46,752, 46,753 (July 10, 1980)(codified at 10 C.F.R. $\$ \S 211.62,211.66(\mathrm{~h}), 211.67,212.131$ (1981)).

266. 45 Fed. Reg. 46,756-59. It was subject to "a uniform entitlement obligation which is in effect the difference between all refiners' reported weighted average acquisition cost for all crudes and all refiners' reported weighted average cost for ANS upper tier crude oil." Id. at 46,752.

267. Interview with William Bode, attorney for OIS (June 23, 1982). 
changes could be shepherded through the intricate pohtical and administrative systems that shape energy policy. In each case, the OHA's speed, independence, flexibility, broad equitable discretion, and managerial talent commended it to the DOE pohicymakers. At the time, "Letting Mel do it" struck harried energy officials as a prudent response to a set of harsh institutional, administrative, and political constraints. The DOE was able to ward off particular threats to large domestic refining operations without cominitting itself to a broad policy of future subsidies, one tliat might be a good deal easier to launch than to terminate. Yet as the OHA's successive orders modifying Ashland's relief demonstrate, this incremental approach entailed certain characteristic risks-in particular, those associated with basing farreaching decisions on a narrow, firm-specific record coinpiled in an emergency hearing before a single, largely autonomous official.

In Ohio Independents, these risks assuined large proportions indeed. Viewed inost charitably (but, of course, in retrospect), Goldstein's actions seem impetuous. He urged OIS to apply for a temporary exception in the face of planned rulemaking activity; he suggested specific remedies to the applicant; he conducted a hearing at whicls problem and remedy were only superficially explored; he rendered an immediate decision; he fashioned an exotic remedy reflecting little if any coordimation with the ERA and perhaps inpeding the ERA's more comprehensive solution. Goldstem did all this under the dubious theory that he was legally compelled to grant relief, yet he chose to ignore the OHA's institutional hinitations and the primary responsibility of the ERA, the larger policymaking apparatus of the DOE. Although Ohio Independents may have been sui generis and not inevitable, it nevertheless illustrates the ease with which an exceptions process can be abused and extended beyond its proper limits. This risk exists whenever an administrator views the flexibility and speed of the exceptions process as adequate justifications for its use, and then proceeds without adequate regard for the significant weaknesses and constraints under which that process operates.

4. The Motor Gasoline Crisis of 1979. The decline and eventual cessation of Iranian crude oil shipnients in late 1978 confronted DOE with its first major crisis since the Arab oil embargo of 1973. By changing its price and allocation regulations too late, too often, and with too hittle warning, the DOE exacerbated the shortage and contributed to President Carter's decision to phase out controls without waiting for the EPAA to expire. The failure of the DOE's policy apparatus swainped the OHA with a volume of exceptions applications far ex- 
ceeding its capacity. This section focuses on the crucial base period provisions of the gasoline allocation regulations. Like the other case studies, it reveals characteristic strengths and limitations of the exceptions process.

a. Background: The motor gasoline allocation regulations. When the shortage struck in early 1979 , the notor gasoline allocation regulations were essentially the same as those that the FEO had adopted five years earher. In order to assure that the distribution of supplies during a shortage would mirror historic consumption patterns, the prescribed base period for each montls was the corresponding month of 1972. In general, a suppher's allocation fraction ${ }^{268}$ determined how much product each retail station or wholesale purchaser would receive froin that supplier. If the product available for distribution was less than the amount the supplier distributed in the same month during 1972 (that is, if its allocation fraction remained below 1.0 ), each retail or wholesale purchaser subject to the allocation fraction methodology would receive the same proportion of the supplier's product that the purchaser had received during the same month of $1972 .{ }^{269}$

Although these regulations remained intact after the shortage ended in the spring of 1974, the availability of "surplus product" (supplies above tlie amount distributed in 1972) rendered them irrelevant. Because most gasoline stations or purchasers could find surplus product whenever they needed it, distribution channels gradually shifted away from the patterns dictated by the 1972 base period. Ncw stations opened, others closed; some expanded, others contracted; many rearranged their relationships with supphers; and the industry shifted from an emphasis on full-service retail outlets toward self-service and "gasoline only" stations. 270

The original regulations had contained several "changed circumstances" adjustments, allowing for upward certification of base period volumes to reflect "unusual growtlr" or other changes in retail volume since the base period. ${ }^{271}$ In August 1974, however, the FEA concluded

268. An "allocation fraction" is the ratio between the amount of product available for distribution in a given month and the supplier's supply obligation for all levels of distribution for that same period, as measured by volumes experienced during the compounding month of the base period. 10 C.F.R. $\$ 211.10$ (b) (1975).

269. 10 C.F.R. $\$ 211.10(f)(1975)$.

270. General accounting Office, Rep. No. EMD-80-34, Gasoline Allocation: A Chaotic Program in Need of Overhaul 23-24 (Apr. 23, 1980) [hereinafter cited as GaO Report].

271. 10 C.F.R. $\$ 211.13$ (1974). 
that its regional offices had granted adjustments so liberally that they had significantly inflated suppliers' obligations and decreased the surplus product available for flexible distribution. ${ }^{272}$ The FEA also believed that large refiners had exploited the adjustment provisions by gaining a share of the adjustments for their fully-owned, branded stations disproportionate to those obtained by independent, non-branded dealers and jobbers. ${ }^{273}$ The FEA therefore eliminated the general adjustments, based merely on "changed circumstances" (i.e., "the potential for mcreased sales and consumption"), ${ }^{274}$ and relegated such "speculative"275 claims to the relatively stringent exceptions process. ${ }^{276}$ Thus, the exceptions process became the only route by which many of the retail stations supplied by the large refiners-or, indeed, many of the refiners themselves-could apply for base period adjustments. Jobbers, however, could still certify base period volumes upward simply by showing imcreased sales by the independent dealers they supplied.277 As a result, the regulated allocation patterns camc to bear less and less resemblance to the actual market and to be disproportionately favorable to jobbers and unbranded independent dealers. ${ }^{278}$

Many energy officials continued to believe after 1974 that outright repeal of all price and allocation controls was botll imminent and preferable to making new adjustments; anachronistic rules strengthened their case for decontrol. ${ }^{279}$ In June 1978, just before signs of an inpending shortage began to appear, the ERA proposed broad standby authority for the ERA to designate a new base period-the 12-montl period ending with the third month (or some other month designated by the ERA) before the month in which there was congressional activation of rationing. ${ }^{280}$ The standby provisions became final on January 12,1979 , just as the shortage struck. The notice explaming the new

272. Adjustments to Base Period Use, Shifting of Entitlements among Gasoline Outlets, and Distribution of Surplus Product, 39 Fed. Reg. 29,601, 29,602 (1974)(Notice of Proposed Rulemaking filed Aug. 14, 1974).

273. Id.

274. $I d$.

275. $I d$.

276. 39 Fed. Reg. $36,854,36,854-55$ (1974)(codified at 10 C.F.R. $\S \S 205.52,211.10,211.13$, 211.106 (1974)).

277. 39 Fed. Reg. 39,854-55.

278. GAO Report, supra note 270. As early as 1976, President Ford's Task Force on Regulatory Reform took notice of this problem, and a proceeding to update the base period was actually initiated in 1977. 42 Fed. Reg. 20,826 (proposed Apr. 22, 1977), 42 Fed. Reg. 36,836 (withdrawn July 18, 1977).

279. 42 Fed. Reg. 20,826 (proposed Apr. 22, 1977); 42 Fed. Reg. 36,836 (withdrawn July 18, 1977).

280. Proposed Contingency Gasoline Rationing Plan, 43 Fed. Reg. 28,134, 28,136 (1978)(adding 10 C.F.R. $§ 500$ ) (proposed June 22, 1978). 
standby rules failed to recognize either the need to adjust for growth after adoption of an updated base period or the danger of market disruptions from abrupt changes in the base period, although ample evidence of both existed. ${ }^{281}$ This failure contributed significantly to the regulatory fiasco that followed.

b. An overview of the crisis. As early as September 1978, Energy Secretary James Schlesinger warned that the United States faced a danger of gasoline shortages the following fall and winter. ${ }^{282}$ Relatively stable international crnde prices and domestic crude prices that regulation had kept relatively low induced unprecedented gasoline consumption that summer, reducing inventories to their lowest level since 19731974; by the end of 1978, product stocks remained seven percent below the level for 1977.283 Meanwhile, the Iranian Revolution had gathered momentum; strikes that had begun at the Abadan refinery in October 1978 became increasingly widespread and foreign oil technicians soon left the country. ${ }^{284}$ After a steady decline in Iranian production, Iran terminated oil exports on December 26, 1978; they did not resume until the following March.

For the first four months of 1979, the United States confronted a net average shortfall of 630-700 million BPD, almost four percent of its total supply. Although this shortage was small compared to the eight percent supply shortfall of 1973-1974, gasoline consumers in some areas faced worse conditions. Long waiting lines first appeared in California in April, and acute shortages spread to eastern urban areas in May and June. Other areas, however, remained largely unaffected. ${ }^{285}$ Government officials offered comphcated and even contradictory explanations. ${ }^{286}$ By mid-summer, gasoline lines had inostly disappeared. Iranian crude exports, 2.2 billion BPD in March when they first resumed, rose to three or four billion BPD in June, approaching the five

281. See Standby Product Allocation and Price Regulations and Improved Allocation Fractions, 44 Fed. Reg. 3928, 3930 (1979)(codified at 10 C.F.R. §§ 210, 211, 212 (effective January 12, 1979)).

282. W. LANE, supra note 97, at 59; see also GENERAL ACCOUNT1NG OFF1CE, REP. No. EMD79-97, Iranian Oil Cutoff: Reduced Petroleum Supplies and INADEQUate U.S. GovernMENT RESPONSE (Sept. 13, 1979).

283. W. LANE, supra note 97, at 60-61.

284. Id. at 61 .

285. Interview with William Funk, DOE Office of General Counsel (June 30, 1982).

286. One Federal Trade Commission official suggested that the major oil companies might have contrived the shortage, but preliminary results of a study done by the Energy and Justice Departments at the behest of President Carter dismissed this charge as early as July 24. See ENergy Policy in Perspective: Today's Problems, Yesterday's Solutions 617-18 (C. Goodwin ed. 1981)(citing U.S. DEPT. OF ENERGY, REPORT to THE PRESIDENT ON THE ACTIVITIES OF Oil Companies Affecting Gasoline Supplies (July 24, 1979)). 
billion BPD level which was typical during the Shah's reign. Two kinds of state and local regulations-maximum purchase requirements and "odd-even" rules-also helped curtail demand.

When changes in the allocation regulations did emerge during the spring and summer of 1979, they came from a coterie of high-level DOE policymakers, with whom Goldstein's argumentative talents and experience earned the OHA great policy influence. Even more instrumental in changing the gasoline allocation rules, however, was the performance of the exceptions process itself. Although the persistent conflicts between the ERA and the OHA often impeded effective coordimation of the rulemaking and exceptions functions, the gasoline crisis compelled the ERA to rely largely on the exceptions process to identify pressure points in the regulations. When the OHA experienced a surge in the volume of exceptions applications directed at a particular problem in the underlying regulations, the ERA could address it. If the ERA failed to respond adequately, the OHA could take matters into its own hands, as we shall see below.

c. OHA in the early stages of the crisis. By the time the standby regulations were in place in mid-January 1979, the shortage had arrived. Several major oil companies had begun rationing gasoline to stations. Several had applied to the OHA for exceptions rehef to allow them to allocate to dealers on the basis of either the 1972 base period or the corresponding period in 1977, whichever was greater. The OHA recognized the mequity in having allowed jobbers to "upward certify" their base period allocations under the regulations, while keeping allocations to dealers directly supplied by the companies at 1972 levels. The OHA generally granted the alternative base periods requested, thereby assuring equal treatment for branded dealers. ${ }^{287}$

In this context, the exceptions process was performing its conventional "safety valve" function, reheving pressure on over-broad rules in individual cases. ${ }^{288}$ Yet these cases also revealed that many refiners would soon begin rationing their supplies under the standby regulations. As the effects of the shortage began to appear, several refiners also petitioned the ERA to implement those regulations by updating the base period. In an Activation Order issued without prior notice or hearing, the ERA finally shifted the base period from 1972 to July 1977-June 1978; "infornnation already provided by major refiners to OHA" had helped demonstrate the need for an updated base period. By implementimg the change without prior notice and comment, the

287. See, e.g., Shell Oil Co., [2 DOE] ENERGy MGMT. (CCH) I 82,043 (Nov. 22, 1978).

288. See infra notes $410-30$ and accompanying text. 
ERA probably exacerbated the gasoline shortage by binding the agency and the industry to many problems created by the new base period. ${ }^{289}$

Only two weeks after the Activation Order became effective, the ERA issued "Guidelines" attempting to clarify two aspects of the new regulations. ${ }^{290}$ First, the guidelines articulated the basis for assigning suppliers and product voluines to new stations and other dealers without base period purchases. Second, they defined the "temporary exigent circumstances" accompanying an unusually low base period volume under which the ERA would raise an apphicant's allocation. The ERA's publication of the guidelines reflected the OHA's exceptions experience; cooperation between the agencies was common during the crisis. The OHA would divide its exceptions caseload imto discernible classes and present them to the ERA, which could address the problems that the cases pinpointed. In this instance, the OHA anticipated the impending deluge of applications for adjustments and the potential overlap between the exceptions process and the ERA's own adjustment procedures. Guidelines to the ERA's adjustments policy would help allay confusion by dealers and suppliers, relieving the OHA of some regulatory burdens.

Still, the exceptions backlog at the OHA, after climbing from 926 in January to 961 in February, jumped to 2612 in March and to nearly 10,000 at its apex in September. ${ }^{291}$ Any comprehensive regulatory framework applying to more than 150,000 service stations was bound to create numerous unanticipated anomalies. Although the ERA recognized that the exceptions process would be necessary "to provide relief to any firms experiencing hardship or gross inequity" due to the new rules, it had predicted that sucl1 cases would be "limited in number."292 Poorly conceived and sloppily drafted rules surely con-

289. 44 Fed. Reg. 11,202 (Feb. 28, 1979). For example, the change required all suppliers to recalculate their supply obligations immediately, often an impractical task. Enormous volumes of supplies had to be rerouted in a matter of days. Disputes over supply obligations commonly added to these logistical probleins, entangling many supply networks in improper allocations, delayed shipments, confusion in routing supplies, and shortages at the retail level. Uncertainty about where supplies should be rerouted and how to apply for individual regulatory adjustments caused massive dislocations. Supphers tended to hold back on deliveries until they could determine their new regulatory obligations. See Senate Comm. on Governmental Affalrs, 97th Cong., Ist Sess., Department of Energy Gasoline allocation Program 14 (Comm. Print 1981) [hereinafter cited as GASOLINE ALLOCATION].

290. 44 Fed. Reg. 16,480 (Mar. 19, 1979).

291. Department of Energy Gasoline Allocation Program: Hearings Before the Senate Permanent Subcommittee on Investigations of the Committee on Governmental Affairs, 96th Cong., 2d Sess. 166 (1980)(statement of Melvin Goldstein) [hereinafter cited as Gasoline Hearings].

292. Gasoline Allocation, supra note 289, at 15. 
tributed to the deluge; indeed, the ERA implicitly acknowledged the inadequacy of its allocation and price regulations by constantly amending them throughout the spring. 293

Nowhere were the deficiencies in the regulations seen more clearly than at the OHA, where officials quickly realized that the flood of apphications would soon exceed the OHA's case processing capacity and detract from the care given individual cases. The OHA could readily categorize most of the early applications. Because increasing a jobber's allocation without imposing an additional supply obligation upon it could confer a competitive advantage greater than that needed to reheve serious hardship or gross inequity, exceptions standards for jobbers had to be more complex than those for retailers. Applications by retailers, the vast bulk of the cases, consisted of four categories. In proposed decisions and orders issued between March 15 and 23, the OHA set out its decision criteria for each category. Flexible judicial-type standards rather than hard-and-fast rules, these criteria would nevertheless help to streamline decisionmaking as the exceptions caseload mounted.

The first category of cases comprised requests by retailers whose business had expanded simce June 1978, the last month of the base period. To qualify for relief under what became known as the Duncan 294 standard, a retailer had to show that: (1) it had sold a "substantially greater" average monthly volume after June 1978 than during the base period; (2) the increase "does not merely reflect a general increased demand for motor gasoline but instead is attributable to a significant alteration in the ongoing business practices of the firm"; and (3) denial of exception relief "will adversely affect the firm to a significant degree and might well jeopardize its continued existence as a viable business entity."295 In the typical case justifying relief, a new owner had purchased the station toward the end of the base period and his aggressive marketing had raised sales volume.

In a second type of case, beginning with Leo Anger, Inc., ${ }^{296}$ the OHA granted relief based upon another kind of growth after the base period. Here, the three criteria justifying an exception were: (1) a "substantial capital investment" made to "realize an economic benefit" through increased sales of motor gasoline by the firm; (2) failure to

293. The GAO couuted no fewer than 27 changes in the gasoline and distillate regulations between January and July. GAO Report, supra note 270, at 15.

294. Duncan Oil Co., No. DEE-2259 (proposed decision issued March 15, 1979).

295. Applications for Exception, Relating to Motor Gasoline Allocation Regulations, 44 Fed. Reg. 40,391, 40,392 (1979)(issued July 3, 1979) [hereinafter cited as Applications for Exception].

296. [4 DOE] ENERGY MGMT (CCH) If 81,037 (June 18, 1979). 
realize the increased volume and consequent economic benefits until after the new base period; and (3) failure to realize the intended benefits, and a "significant" adverse effect in the absence of an exception. ${ }^{297}$

A third standard, announced in Harrison Gas and Oil, ${ }^{298}$ required that (1) "unusual or anomalous events occurred during a base period" which (2) made the base period inappropriate as a measure of "relatively normal and customary period of business activity," and (3) "the consequent distortion . . . has adversely affected the firm in a significant inanner."299 These criteria substantially overlapped with those for the "teinporary exigent circumstances" adjustment adininistered by the ERA. ${ }^{300}$

Finally, the OHA gave relief where the energy shortage unfairly burdened residents of a community in which a retailer was located. In James Tidwell Chevron, ${ }^{301}$ for exaunple, the OHA granted a higher allocation to one of two stations in a sinall community in which increased deinand had resulted partly froin closings of two other stations. The criteria the OHA used here were: (1) higher motor gasoline deinand "as a result of a significant change in the circumstances under which the product is supplied or used"; (2) inability of the firm to purchase surplus gasoline; and (3) frustration of one or more of the policy objectives of the EPAA as a result of the inability of the firm to obtain additional product. ${ }^{302}$

d. The "unusual growth" adjustment. The Duncan, Anger, Harrison, and Tidwell standards were not adopted as forunal rules. The OHA officials had quickly recognized that many requests for relief under these standards refiected the failure of the ERA's rules under the Activation Order to adjust for an entire category of stations-those that increased their average sales during the nine inonths following the end of the base period and that needed additional allocations to serve new custoiners. Considering that such an adjustment had clearly served a useful purpose in the 1974 regulations, this ornission im the new ones was obviously mistaken. The ERA inay have tolerated or even en-

297. Id. at 82,653 . In Anger, the new investinent that qualified the retailer was over $\$ 500,000$, $i d$, but other cases found sums as low as $\$ 47,000$ to be substantial. See Applications for Exception, supra note 254, at 40,393-94 (referring to Howard Moore, No. DEE-2604 (March 30, 1979)).

298. [4 DOE] ENERGy MGMT. (CCH) I 81,033 (June 20, 1979).

299. Id. at 82,638 .

300. See infra notes 320-21 and accompanying text. Illness of the owner or lighway construction in front of the station were events that typically justified Harrison relief; applicants that had experienced growth simce the new base period, including stations initially established durimg the base period, often qualified as well. 44 Fed. Reg. at $40,395$.

301. James Tidwell Chevron, [5 DOE] ENERGY MGMT. (CCH) ๆ 81,262 (June 8, 1979).

302. 44 Fed. Reg. 40,391, 40,396 (1979). 
couraged such defects in the regulations in the belief that any serious problems would be handled by the exceptions process. Implementation of rules without a prior hearing and comment period probably contributed to the errors, as did incompetent lower-level ERA staff work and hasty draftimg encouraged by the crisis atmosphere. Nevertheless, high level officials in both the ERA and the OGC worked on drafts of the regulations, which circulated to the OHA and other DOE units for comments before being issued. They too must share the responsibility. The rulemakers' failure to anticipate that the absence of an adjustment rule during a severe shortage would cripple the exceptions process surely constituted a serious regulatory error, one among many during the gasoline crisis.

The OHA's inost significant change in the allocation base period rules that spring, the "unusual growth" adjustment, sought to correct this failure. As the backlog of exceptions cases continued to rise, almost doubling in April 1979, a majority of the pending exceptions cases involved retail outlets that had experienced "substantial growth" after the end of the base period. OHA officials contimued to emphasize to the ERA and to the Deputy Secretary the need to reheve the pressure on the exceptions process by changing the rules. The OHA safety valve had not been designed to bear the full force of the regulatory program; a second safety valve had to be devised. The OHA proposed a new rule that would simply prescribe, across-the-board, what percentage growth would qualify a station for an increased allocation. This rule would be much easier to administer than the more general exceptions standards, and would eliminate much of the OHA's massive backlog. Eventually, the OHA and the ERA worked out the general outlines of the necessary rule, ${ }^{303}$ but such details as whether the adjustinent would be mandatory and where new supplies under the adjustment would come from remained unresolved. The ERA therefore was not able to promulgate the new rule in time to cover supphiers' obligations for April, and the OHA had to deal with hundreds of additional exceptions requests that the rule could have obviated.

303. Telephone interview with Joel Yudson, ERA staff official (June 28, 1982). The new provisions for allocations in April apphed to retailers and wholesale cousumers that purchased an average monthly volume of gasoline during the period from October 1978 through February 1979 that was $35 \%$ greater than their average monthly volume for the normal base period month of April 1978. These retailers and consumers would receive allocations determined by their average monthly volume from October 1978 through 1979 rather than April 1978. For May, retail outlets and wholesale consumers could use average monthly volume for October 1978 through February 1979 as their base period volume if it was $10 \%$ above their normal base period volume of May 1978. 
The OHA/ERA solution to this dilemma entailed an innovative use of the OHA's exceptions authority to issue what amounted to a fullfledged rule. On April 18, the ERA issued a "Notice of Intent to Issue a Final Rule." 304 The notice of intent, which ERA had seldom used before, invited public comments upon an "Interim Final Rule" incorporating the "unusual growth adjustinent" into the regulations. ${ }^{305} \mathrm{But}$ the notice also enabled the OHA to issue an extraordinary industrywide "class exception" the very next day, immediately implementing the "unusual growth" adjustment for April under the identical formula that the ERA had just announced it intended to apply. ${ }^{306}$

The OHA had issued class exceptions before but probably none so closely resembled a legislative-type rule as the one issued on April 19, 1979. Following the Activation Order, for example, Amoco and other majors had apphed for exception relief on behalf of their numerous branded retail outlets, and the OHA had generally granted class relief under the Duncan, Anger, or Harrison standards. ${ }^{307}$ But this form of class relief bore little resemblance to the class exception issued April 19. First, the OHA initiated the latter proceeding itself. ${ }^{308}$ Second, the OHA did so not only on behalf of those firms that had filed for exception relief, ${ }^{309}$ but also for all parties that met the criteria for class membership. Retailers and wholesalers did not even have to apply to the

304. Notice of Intent to Issue a Final Rule, 44 Fed. Reg. 23,537 (Apr. 20, 1979).

305. After the rule was issued, the ERA would solicit comments and hold a hearing. Interim Final Rule, 44 Fed. Reg. 26,712 (May 4, 1979).

306. Class Exception Relating to Motor Gasoline Allocation Regulations, 44 Fed. Reg. 24,024 (Apr. 23, 1979).

307. The criteria that the OHA had used as prerequisites for class exception in $A m o c O$, and as far back as 1976, tracked the criteria in Rule 23 of the Federal Rules of Civil Procedure. According to these criteria, a class action could be inaintained

only if (1) the class is so numerous that joinder of all members is impracticable, (2) there are questions of law or fact common to the class, (3) the claims or defenses of the representative parties are typical of the claims or defenses of the class, and (4) the representative parties will fairly and adequately protect the interests of the class.

FED. R. Crv. P. 23.

308. In explaiming the class exception, the OHA did not evaluate its own ability to represent the interests of the class of retailers and wholesale consumers whom the absence of a growth adjustment had disadvantaged. Instead, the OHA simply ignored its own role in initiating the procedure, taking those that had already applied for exception relief, because of the conditions common to the class, as the representatives who presented claims typical of the class. See 44 Fed. Reg. 24,028-29 (1979).

309. The OHA would take such action in at least one subsequent case during the crisis. See Class Exception and Proceedings Concerning Extension of Relief Previously Granted in Certain Motor Gasoline Allocation Cases, [4 DOE] ENERGY MGMr. (CCH) If 81,049 (June 18, 1979); Second Class Exception Proceeding Involving Extension of Relief in Certain Motor Gasoline A1location Cases, [4 DOE] ENERGY MGMT. (CCH) If 81,174 (Oct. 22, 1979)(granting extensions of relief to 98 firms under the Anger and Tidwell standards). But see American Petroleum Refiners Ass'n, [3 DOE] ENERGY MGMT. (CCH) I 81,094 (Apr. 9, 1979)(denying class relief on grounds that proposed class not so numerous as to preclude individual applications). 
OHA for class certification. Unlike the provision in the Amoco class exception that had allowed Amoco to determine whether its retailers met specific criteria for relief, the OHA's order here benefited persons and firms without even an indirect connection to an exceptions application, and extended benefits not simply to one company's retailers but to qualifying firms throughout the industry.

In effect, then, the OHA's industry-wide order was indistinguishable from an ERA rule, in substance if not in form. To justify this, the OHA pointed to the practical inevitability of class relief, citing the ERA's notice of intent, previous exceptions cases such as Duncan and Harrison, and the low cost of administering this remedy. The OHA could avoid hundreds of exceptions cases, since suppliers and retailers no longer had to apply for relief in order to adjust relationships falling within the class. ${ }^{310}$

Public comments, however, highlighted a crucial and systematic flaw in the OHA's novel action. The OHA's fact-finding had been based only on the exceptions cases before it. Sonne serious difficulties with the proposed rule, identified by public commentators in the rulemaking proceeding, had been neglected by the OHA when it designed its class exception. First, the OHA's order simply decreed a base period volume for those in the class of the average monthly purchases during October 1978 through February 1979. This order failed to clarify one of the most controversial issues in the ERA rulemaking: whether the substitute base period was to be automatic and mandatory or wonld depend upon purchasers' applying to their supphiers for certification. ${ }^{311}$ Second, the OHA brushed over an issue that some commentators had identified to the ERA: which supplier would be obligated to supply the increased volume to a retailer. Instead, its order simply provided that the new volume would be provided by the prime suppliers if they were base period suppliers, or, if not, then by any nonprimary supplier. Uncertainty over which nonprimary supplier would be required to supply the additional volume could have enabled all potential suppliers to deny any obligation to a pur-

310. 44 Fed. Reg. 24,028-29 (1979).

311. In its May 1 Interim Final Rule, the ERA itself adopted a more complicated provision that generally made the adjustment mandatory, but made mandatory upward certification im certain cases contingent upon application by the retailer or wholesale consumer to its base period suppliers. Under the class exception, especially in instances where the identity of the proper supplier of additional product was unclear, any potential supplier could deny responsibility to grant the purchaser an upward certification unless the purchaser applied for it. See 44 Fed. Reg. 24,029 (1979); 44 Fed. Reg. 26,715, 26,717, 26,722 (1979). 
chaser that apphed to them. ${ }^{312}$ Third, the OHA also failed to address a broader defect of the unusual growth adjustment identified in comments to the ERA: the regional differentials created by the October 1978-February 1979 substitute base period provided by the new adjustment. The substitute base period, commentators argued, would disadvantage areas with low historical purchases during winter months and favor those with high winter purchases. ${ }^{313}$

These defects in the OHA's remedy cannot be dismissed as simply products of hectic emergency decisionmaking or of the energy industry's complexity. More fundamentally, they reflect the limitations of the exceptions process from which the OHA's rule emerged. The OHA's exceptions cases accuinulated convincing evidence that an "unusual growth adjustment" of soine kind was needed. But they shed little hight upon how a comprehensive regulatory solution might be fashioned, especially in its crucial details. The OHA's narrow adjudicatory focus, well suited to its normal function of devising individual remedies, made it very difficult to design a policy that would make sense industry-wide. The OHA was equitably preoccupied with potential injury to individual firms caused by failure to grant relief, rather than with the broader impact of its orders. Overarching "legislative facts," such as effects on regional disparities, were naturally obscured in the individual cases upon which the class remedy was based.

The OHA's class exception, lowever, was not disastrous. Its threshold requirement of thirty-five percent growth froin the base period allowed relief for April only in what the ERA would later call "extraordinary circumstances." It was never clear how many flruns were affected. The total, perhaps in the hundreds, was certainly far below the thousands of stations affected by the ten percent growth adjustment for May that the ERA allowed in its Interim Final Rule. The class exception's narrower ambit hinited the effects of inevitable remedial difficulties and the potential for regional distortions. Finally, the emergency that prevailed and the uncertamties of the ERA's rulemaking process may well have justified the OHA's innovative remedial intervention. Indeed, without this action or something like it, the exceptions backlog would have grown even inore unmanageable than it did. As a result inany more retailers, wholesale purchasers, and consumers would have suffered.

312. Again, the ERA's May 1 rule provided a specific process by which base period and other suppliers could calculate the volume each was obligated to supply to the rctailer or wholcsale purchaser-consuiner.

313. At the urging of White House officials and the Inter-agency Task Force, the ERA studied the issue, but reached inconclusive results. 
e. The floodgates open. Besides initiating the unusual growth adjustment, the ERA's May 1 rule also changed the base period a second time, from July 1977-June 1978 to November 1977-October 1978. ${ }^{314}$ These many rule changes doubtless swelled the backlog of exceptions at the OHA, which continued to rise from 5440 in May to 7096 in June, to an eventual peak of 9864 in September. ${ }^{315}$ Even the OHA's "unusual growth" adjustment, clarification of the "temporary exigent circumstance" adjustment, and similar refinement of rules for new stations had failed to reverse this relentless tide. Indeed, the OHA found it necessary to continue to grant exceptions relief under the Duncan, Anger, and Harrison standards even after the ERA had implemented the unusual growth adjustment. ${ }^{316}$

The two adjustments built imto the ERA's rules-concerning allocations for new stations and for teinporary exigent circumstances-also failed to reheve the OHA's exceptions burden. Assigning volumes to new stations, while superficially straightforward, created new and severe problems. The owner of a new station would request an ERA regional office to determine the allocation to which it was entitled, based on the volume of the nearest "comparable" station. Each ERA regional office, however, tended to develop different criteria for applying that standard. Moreover, the ERA continued its liberal policy on assignments, encouraging the opening of as inany stations as possible, even after the 1979 shortage struck. ${ }^{317}$ Yet at the same time, the OHA

314. 44 Fed. Reg. 26,716 (1979). The April 18 notice had announced the ERA's intention to change the base period to calendar year 1978 rather than to the base period actually adopted only two weeks later. The purpose, of course, was to adopt the most recent and, arguably, most representative base period possible, thereby minimizing the need for individual exceptions. By failing to act until three months after the activation order was issued, and by first proposing a 1978 base period that inexplicably ignored the market distortions that the Iranian cutbacks had already begun to create in 1978, the ERA again revealcd its serious policy weaknesses. Because the November 1977-October 1978 base period prescribed the same allocations for May and June 1979 as did the July 1977-June 1978 base period, the ERA hoped that its new rule would require hittle rerouting of supplies. Yet these rule changes, along with at least 25 others during the crisis, see supra uote 293 , saved great confusion and uncertainty throughout the industry at a time when clear guidance was essential.

315. See DOE Gasoline Allocation Program: Hearings Before the Senate Permanent Subcommittee on Investigation, 96th Cong., 2d Sess. 166 (1980).

316. For exainple, the OHA still granted relief under Duncan to firms that began operations during the October 1978-February 1979 substitute base period; under Anger when the new base period failed adequately to represent the growth a firm had experienced as a rcsult of investinents that occurred late in the new base period or after it had ended; and under Harrison when the new base period "failed to reflect (the firm's) normal and customary business practices." See, e.g., Frank Moody's Mobil Station, No. DEE-2635 (proposed decision issued April 5, 1979)(relief granted under Duncan); S\&S Petroleum Sales, No. DEE-3335 (proposed dccision issucd May 22, 1979)(relief grauted under Anger); R.C. Stroth, No. DEE-2301 (proposed decision issucd May 25, 1979)(relief granted under Harrison).

317. Interview with Doris Dewton, supra note 203. 
denied most exceptions requests by existing stations for increased volumes. ${ }^{318}$ Thus, an oil coinpany could actually obtain an assignment for a new station more easily than it could obtain increased supplies for an existing one. This preference for new stations enabled aggresive marketing organizations to increase market shares in a new area at the expense of existing dealers. It was both anomalous and inequitable at a time when there existed a severe, agency-administered shortage.

The ERA's regional staff tended to be poorly trained and managed. As a result, both substantive consistency and procedural fairness in assignment proceedings often suffered. Although the OHA was loathe to use its power to review the ERA's assignment orders to dictate their substance, the OHA continually remanded appeals of assignment decisions to the ERA with instructions to clarify the grounds for decisions and to observe procedural requirements. ${ }^{319}$ A growing number of incoming cases, processed slowly by the regional offices, created an ERA backlog comparable to the OHA's. Many retailers and other purchasers, uncertain about how and when the ERA and the OHA would decide their cases, applied to both; if the ERA did not process their assignment or other adjustment quickly, the OHA might perhaps grant relief in the interim. Despite regulatory provisions allowing exceptions only in the absence of a more appropriate proceeding, neither office acted systematically to discourage such duplicate applications.

An additional mechanism designed to relieve pressure on the exceptions process was the ERA's "teinporary exigent circumstances" adjustment. This adjustnient allowed purchasers and suppliers to work out increased allocations for inonths whenever unusual, isolated circumstances, such as highway construction around the station, had artificially lowered base period volume. The ERA did not itself adninister this adjustment, but had to be notified wlien such an adjustment was made. Despite the ERA's efforts to clarify what night constitute "temporary exigent circumstances," purchasers and suppliers continued to disagree about when the adjustment applied. ${ }^{320}$ Moreover, this adjustment overlapped with the Harrison standard for exception relief, encouraging purchasers to pursue both reinedies simultaneously. ${ }^{321}$

318. Overall, the OHA granted exceptions in 1979-1980 in $27.5 \%$ of the retailer cases it processed. See Senate Hearing, supra note 315, at 184. No comparable records exist for ERA assignments.

319. Interview with Richard Dugan, OHA Assistant Director (July 1, 1982).

320. See, e.g., Interview with Doris Dewton, supra note 203.

321. Presumably to eliminate the most complicated "temporary exigent circumstances" cases, the ERA discontinued the adjustment for middle level marketers (jobbers) in its May 1 lnterim Fimal Rule. See 44 Fed. Reg. 26,719 (1979). Thereafter, such purchasers would have to rely solely on exceptions relief, further burdening the OHA. 
The OHA addressed its staggering workload problem in several ways. The Duncan, Anger, Harrison and Tidwell standards enabled the OHA to issue "form decisions," using standardized language and holdings, for perhaps 70 percent of its exceptions cases. Especially after May 1979, the OHA's regional offices were strengthened so that they could dispose of routime cases. Five of the ten regional offices became "regional centers" with nearly twenty einployees. Before, they had been staffed by only one or two people and were barely equipped to process their mail. OHA officials from Washington personally established the facilities during the late spring and early summer, training employees to process cases better and faster. ${ }^{322}$ By 1980, regional centers handled groups of cases from other regions whenever the OHA's headquarters saw opportunities to even out caseloads. Moreover, regional centers even handled some appeals from each other that otherwise would have gone to Washington for processing. Generally, however, the centers handled routine cases or forn decisions. They referred more comphicated cases to Washington. Regional processimg of many exceptions cases also made it easier for small dealers, the vast bulk of exceptions applicants during the shortage, to seek relief. The normal individualized exceptions process was onerous for sunall businesses. They had either limited resources or simply too httle at stake to prosecute exceptions cases. These cases often involved technical proceedings in which a lawyer might well be necessary. Regional centers reduced, but could not eliminate, the considerable expense of preparing for and attending a hearing.

Reform of regional offices occurred too late to assist the OHA in the crucial early months of the sliortage. Other measures were therefore necessary to process the flood of exceptions cases. Through the "consohdated denial," the OHA luniped together a group of cases that failed to qualify under any of the standards, and denied all the applications in a smgle decision. Much of what this procedure gained im efficiency, however, it lost by reducing the thoroughness provided individual applicants once the OHA's analyst had classified them. The OHA attempted to address this problem by issumg its consolidated denials in proposed form. This permitted dissatisfied apphicants to pursue their claims by filing objections to the proposed order. ${ }^{323}$

322. The total number of determinations from Regional Centers, including Proposed Decisions, Final Decisions, and other administrative case closings climbed from 75 in April to 358 in May, and reached 2467 in December before it subsided to an average of 1000 to 1500 cases a month during the first half of 1980. See Gasoline Hearings, supra note 291, at 167.

323. According to the OHA, the objection rate was no higher for firms whose denials were contained in consolidated proposed decisions than for those that received individualized proposed denials. Letter to author from Kenneth A. Wasch, OHA Asst. Director, March 18, 1983. 
The enormous caseload compelled OHA staff to sacrifice careful analysis and opinion writing for speed in processing cases. Traditionally these had been two of the OHA's strengths. The burgeoning exceptions caseload also impaired the quality of administrative review of OHA decisions. Deluged by thousands of routing decisions, the DOE's internal review committee agreed durimg this period to discontmue regular meetings and instead to review written decisions circulated by the OHA, a system that failed to provide an effective departinental counterweight or review inechanisin for exceptions decisions. ${ }^{324}$

Delays were an inevitable consequence of the OHA's backlog. ${ }^{325}$ Especially during the gasoline shortage, equity delayed was often equity denied. The failure of a local dealer to receive his allocation within a few weeks might well compel him to close the station. And even for dealers that managed to survive in the face of OHA delay, a grant of relief afterwards, when supply was plentiful again anyway, was tantamount to a denial. Well aware of this, the OHA regularly screened incoming cases to determine if consideration of teinporary exception relief was appropriate. After May, hearings to grant such relief were usually held in the regional offices. The hearings, lasting two to four hours, typically included presentations by the applicant, its supplier, and sometimes its competitors. Temporary exception decisions usually evaluated only the evidence in the initial subinissions and the hearing itself. Suppliers, conscious of legal expenses and anxious not to be caught in the cross-fire between numerous competing and desperate purchasers, tended to ignore these hearings or offer only very general comments. This passivity constituted yet another obstacle to accurate fact-finding.

f. Conclusion. The notor gasoline shortage of 1979 produced an administrative crisis for the exceptions process, a crisis that called into serious question the possibility of regulatory equity under conditions of severe shortage. As OHA officials candidly acknowledged, even the agency's best efforts could not succeed in sustaining the traditional high quahty of its equitable process. Routinized, long-deferred, and hastily rendered decisions inevitably conipromised the accuracy

324. Telephone interview with Joyce King, former ERA official (July 2, 1982).

325. Officials estimate that the case disposition averaged 30 to 60 days, and that particular cases could take much longer. An applicant's inability to understand the legal standards or the factual information that the OHA required often aggravated these delays. Although the OHA generally tried to process applications im the order filed, its analysts had some incentive to decide the simplest cases first; this decreased the number of pending cases more quickly but left the more difficult and time-consuming cases, such as those brought by resellers, undecided for even longer periods. 
and responsiveness of the process and impaired public confidence in its fairness. ${ }^{326}$

The interesting and important questions, however, are why this breakdown occurred and why it was permitted to continue. In large measure, this problein-like so many at the DOE during the period of controls - can be traced to the deficiencies of the policy development and rulemaking processes. By attempting to administer coinprehensive regulatory controls in an immensely complex, exceedingly dynamic market, the DOE ensured that numerous exceptions to its rules would be sought. By waiting until the crisis was upon it before undertaking to change its rules to account for shortage conditions, the DOE also ensured that it would make policy under the least favorable circuinstances. By adopting new rules abruptly and without adequate public participation, and then constantly having to change those rules, the ERA maximized uncertainty and increased the pressure on the exceptions process. As policy initiative shifted by default froin the ERA to the OHA, the exceptions process inescapably became a vehicle for regulatimg the mdustry. In a metaphorical sense, the safety valve became an autonomous generator of new pressures threatening the system; in a literal sense, the exception became the rule. A process designed for one purpose and einmently successful at achieving it had been obliged, without really altering its fundamental administrative character or resources, to discharge a very different function. What is to be wondered at is not that it failed but that it managed to succeed as well as it did.

\section{An Analysis of the DOE's Exceptions Process}

The predicaments of federal energy policy fundainentally shaped the DOE exceptions process. For example, the shortages of imported crude and the market distortions created by the tiered price of crude directly influenced the OHA's caseload and agenda. The regulatory structure, especially that of the entitlements program, conferred extraordinary power upon the DOE-nothing less than the ability to impose what amounted to a tax on crude oil, and to allocate the tax aunong refiners. Exceptions relief to any single refiner necessarily had industry-wide effects. When the OHA relieved one firm of an entitlement purchase obligation, the OHA thereby increased the costs of crude proportionately to all other firms in the industry, to their customers, and ultimately to the consumers of their products. The buy-sell program empowered the DOE to order any firm to sell to or buy from

326. See, e.g., Gasoline Hearings, supra note 291, at 92-142 (testimony of gasolime dealers); see also Interview with Richard Dugan, supra note 319. 
any other firm in the industry. This power vastly increased the OHA's remedial capability.

To understand the role of exceptions in the regulatory process, however, one must look beyond the pressures of external crises and the structure of regulatory authority. One must also examine the particular, regularized patterns of administrative activity, informal relationships, and latent functions that characterized exceptions decisionmaking. This Part distills from the earlier case studies some important patterns and explores certain problems that they generated.

\section{A. Personalizing Bureaucratic Power.}

A defining and legitimating feature of bureaucracy is the impersonality of bureaucratic-legal authority. Whereas authority in other systems of power is legitimated by the religious or charismatic character of the individual wielding it, bureaucratic-legal authority derives its legitimacy from the respect accorded to rules, precedents, records, logic, and other more objective sources rooted in process rather than in personal attributes. ${ }^{327}$ Nevertheless, many individual bureaucrats, such as J. Edgar Hoover, Hyman Rickover, and Robert Moses, have managed to place their personal imprints upon bureaucratic process to such a degree that their agency's character, public reputation, and perhaps even its legitimacy came to be identified with the individual who wielded the power.

On a far smaller scale, this was true of Melvin Goldstein. From the inception of the exceptions office in early 1974 until his departure from the agency in September 1980, Goldstein dominated the exceptions process so completely that to understand and evaluate that process one must know how he conceived of and executed it. ${ }^{328} \mathrm{He}$ and several OHA aides had administered price controls in general, and exceptions relief im particular, continuously simce the early 1970's, well before the EPAA was enacted. Few other energy bureaucrats could boast such experience and continuity of leadership. Goldstein, a civil service employee who in 1978 became part of the Senior Executive Service, personally and painstakingly recruited a staff generally acknowledged to be among the most highly motivated, talented, and pro-

327. 2 M. WEBER, ECONOMY AND SOCIETY 956-58 (E. Fischoff trans. 1978).

328. Virtually all of the scores of individuals interviewed in preparation of this article appeared to agree with this proposition. Almost without exception and without proinpting, they praised Goldstein's intelligence, managerial efficiency, policy sophistication, personal courage, and visionary leadership. Even those who vigorously disagreed with some of his tactics and decisions-and there were many-emphasized his personal integrity, intellectual independence, and bureaucratic skills. 
ductive in the Department. ${ }^{329}$ The OHA staff tended to dominate intradepartmental policy debates due to their generally superior analytical and legal skills, persuasive abilities, and efficiency at turning out written materials. Although sometimes criticized as arrogant, over-eager, and mexperienced, the staff was crucial to the OHA's pervasive influence upon energy policy.

Goldstein also possessed a clear and distinctive conception of the exceptions process and its role im energy policy.330 Goldstein believed that rulemaking was an inherently limited tool for regulating tlie petroleum industry. First, general rules were almost invariably overbroad as applied to so large, complex and diverse an industry; urgent needs for relief were inevitable and had to be dealt with case-by-case. Second, the regulatory controls were fundamentally experimental; ruleinakers could readily predict neither the problems requiring regulatory intervention nor the consequences of particular policy choices. Prudent regulators, therefore, would defer rulemaking as long as possible. Third, energy regulation required swift decisions that were flexible and responsive to rapidly changing market conditions yet grounded in a carefully compiled administrative record. The conventional rulennaking process, even one that invoked the more summary procedures available under the APA, simply could not be relied upon to generate such decisions. This shortcoming was not only endemic to the formal procedures mandated by law, but also reflected the chronic inadequacy of the program offices, notably the ERA.

For all of these reasons, Goldstein viewed the OHA as the "Lone Ranger" of the regulatory process, an institutional "white knight" of energy policy. The OHA could be counted on to make the hard decisions from whicl otliers recoiled, enabling the regulatory apparatus to function efficiently and fairly, to produce high quality decisions, and to overcome the ERA's failures. Perhaps inore importantly, most otler key energy policymakers acquiesced in these views and did not resist Goldstein's steady accumulation of policy influence. Indeed, as will be shown, other energy policymakers encouraged the OHA to discharge many crucial functions in the regulatory process. ${ }^{331}$ Under these circumstances, an aggressive, activist exceptions process was probably inevitable. But Goldstein's personalization of bureaucratic power was

329. Many were hired in personnel categories (e.g., Schedule A for lawyers, Schedule B for analysts) not subject to the conventional civil service constraints.

330. This reflected his earlier experience administering exceptions relief at the Cost of Living Council during Phase 4.

331. See infra text accompanying note 425 . 
neither inevitable nor, from the larger perspective of administrative law, desirable.

\section{B. Expansive Conception of the Exceptions Function.}

Many federal agencies either have no discrete exceptions process or have processes that are narrow in jurisdiction, reactive in nature, and marginal in pohicy significance-in short, exceptions processes designed to achieve regulatory equity proper. ${ }^{332}$ The only question in hardship cases, where the pohicy and rule are more or less taken as already established and to be reaffirmed, is whether the individual applicant "fits" or not.

Goldstein conceived of the OHA's role very differently. To Goldstein, as well as to most of the key policymakers at the DOE, the exceptions process should play a far broader, inore affirmative, essentially policy-shaping role. The OHA should not simply exainine individual cases to see whether they fit within preexisting standards. Instead, it should sometimes decide initially just what those substantive standards should be and how they ought to be imterpreted, apphed, modified, and effectuated. To these policymakers, the DOE's exceptions process should not siniply operate as an instrument of regulatory equity but should use adjudication as a tool for policy development and implementation.

This remarkably expansive conception of the exceptions process was in fact realized at the OHA, especially after the entitlements program was maugurated $\mathrm{m}$ late 1974 . Indeed, the range, novelty, and impact of OHA policy interventions are astonishing; the case studies im Part II discuss only a subset, although an important subset, of them. The OHA designed a complex system of subsidies and adjustments for small refiners; 333 adopted a comprehensive system for allocating refined petroleum products for the District of Columbia; ${ }^{334}$ intervened to shore up the economy of Puerto Rico; ${ }^{335}$ sought to stimulate the production of gasohol; ${ }^{336}$ pressed for reimposition of regulatory controls

332. See P. ScHUCK, supra note 50, at app. G (the author's analysis of agency responses to an Administrative Conference questionnaire concerning their exceptions processes).

333. See supra notes 140-205 and accompanying text (Delta-Beacon case study).

334. The District of Columbia, No. DEZ-0058 (Interlocutory Order filed Jan. 4, 1980)(summarized at 45 Fed. Reg. 1452 (1980)).

335. See e.g., Commonwealth Oil Refining Co., [4 DOE] ENERGY Mamt. (CCH) (1979) ๆ 81,118 (Aug. 15, 1979).

336. See e.g., Welsh Oil, Inc., [6 DOE] EnERGy Mamt. (CCH) \ 81,038 (June 24, 1980); American Agrifuels Corp., [4 DOE] ENERGY MGMT. (CCH) If 81,139 (August 28, 1979), affd sub nom. Amoco Oil Co. v. DOE, 490 F. Supp. 1016 (D.D.C. 1980). 
over home heating oil;;37 established a new policy on the regulation of natural gas liquids; ${ }^{338}$ rearranged long standing supply and marketing relationships among thousands of firms; $; 39$ and subsidized new production processes, capital construction projects, and transportation arrangements. 340 In each of these decisions, and in many others, the OHA transcended the traditional boundaries of regulatory equity and "hardship" adjudication to create legislative-type regulation of the most far-reaching kind. In almost every case, it did so with the apparent knowledge and support of the departinental leadership. ${ }^{341}$

\section{Autonomy.}

Goldstein was convinced that the exceptions process should assiduously cultivate and jealously preserve independence froin the kinds of political and bureaucratic influences to which policymaking, and especially rulemaking, activities are normally subject. He believed such independence was essential, due to the individualized nature of OHA decisions and the need to avoid any suspicion of impropriety in connection with decisions in which many millions of dollars in regulatory relief and important inarket advantages were often conferred upon individual firms and denied to their coinpetitors.

Goldstein managed to wrest this autonomy for the OHA only over time and only through skillful bureaucratic tactics, including a threatened departure from the agency. He insisted upon the OHA's independence at every opportunity. By emphasizing the OHA's adjudicatory face, he was able to project the image of the detached decisionmaking and procedural integrity normally associated with the judicial model of decisionmaking. Although this appeal to the ethos of adjudication is behed by the strikingly legislative character of inany OHA decisions, it appears to have been a simgularly effective tactic in persuading the DOE political leadership, as well as members of Congress and their staffs, to respect the OHA's independence.

Goldstein confirmed and strengthened the OHA's autonomy in other ways. During the FEO and FEA periods, the OHA utterly dominated the committee that reviewed the exceptions decisions. The Administrator reviewed decisions only in the very rare case when the offices could not reach agreement. The first DOE organization plan,

337. No. 2 Home Heating Oil: Decision and Recommendations, [2 DOE] ENERGY MGMT. (CCH) $\uparrow 82,543$, at 85,085 (1978).

338. Class Exception, [1975 Transfer Binder] ENERGY MGMT. (CCH) | 84,901 (1975).

339. See supra notcs 268-326 and accompanying text (Motor Gasoline case study).

340. See, e.g., supra notes 248-67 and accompanying text (Ohio Independents case study).

341. O'Leary interview, supra note 137. 
however, lodged the OHA within the ERA. The OHA was taken out of the ERA structure only after Goldstein insisted that if it were not, the independence of the exceptions process would be compromised. Instead, the OHA Director would report directly to the Secretary of Energy. ${ }^{342}$ Goldstein also inanaged to neutralize the effect of section 504(b) of the DOE Act. ${ }^{343}$ That section explicitly provided for appellate review of exceptions decisions by the quasi-independent Federal Energy Regulatory Commission (FERC). It accomplished this by mandating a new appeals process within the OHA as a prerequisite to seeking FERC review. 344 After departing from the DOE in February 1978 , Goldstein agreed to return only upon the express condition that the jurisdiction of the administrative review cominittee created to review and clear exceptions decisions be confined to final OHA orders and not extended to grants or denials of temporary or interim relief. ${ }^{345}$ According to several senior DOE officials, Goldstein avoided attending senior staff meetings unless specifically directed to do so by the Deputy Secretary, and thus missed most of them. ${ }^{346} \mathrm{He}$ met congressional inquiries about the status of pending exceptions cases with polite but firm reminders that the integrity of the process must not be comproinised. ${ }^{347}$

Ultimately, the most important assurance of the OHA's autonomy was the commitment of the Department's political leadership to a policy of virtual noninterference with OHA decisions. This commitment reflected the Secretary's perception that Goldstein's pohtical instincts, policy judgments, and conception of the exceptions process as an affirmative regulatory tool comported essentially with his own.

\section{Indeterminate Equitable Standards.}

Because the limits and inadequacies of rules usually make resort to equity seem necessary or prudent, one would expect equitable criteria

342. In practice, the OHA Director reported to the Deputy Secretary. Department of Energy Delegation Order No. 0204-24 (March 30, 1978).

343. § 504(b), 42 U.S.C. $\$ 7194$ (c) (Supp. V 1981).

344. 44 Fed. Reg. 16,890 (Mar. 20, 1979); cf. Administrative Conference of the United States, Recommendation No. 80-2, reprinted at 1 C.F.R. § 305.80-2 (1983).

345. Cominittee review of even final orders, inoreover, was effectively aborted by Goldstein's control of the review process and his imposition of very short time limits for the other offices to submit objections. See supra notes $137-38$ and accompanying text.

346. Interview with Hazel Rollins, supra note 233; interview with Robert Montgomery, former General Counsel, FEA (May 21, 1982). Goldstein's own recollection differs. Telephone interview with Melvin Goldstein (December 30, 1982).

347. Interview with David Schooler, supra note 182. Unlike many DOE bureaucrats, Goldstein did not protest against the OHA's offices being located at some distance from the building that housed the Secretary and Deputy Secretary. Interview with David Bardin, former ERA Administrator (June 1, 1982). 
to take the form of highly indeterminate standards. In fact, the OHA's exceptions criteria have been exceedingly broad. Energy legislation has always prescribed three standards; relief must be necessary to prevent (1) "hardship," (2) "inequity," or (3) "unfair distribution of burdens."348 Beginning with the FEO period, the exceptions office elaborated these extremely ambiguous standards case-by-case, rather than developing them through rulemaking. Although a large number of routme cases could readily be decided in this way, the standards, even as elaborated, remained so broad that the office was essentially free to grant or withhold exceptions relief as it saw fit. ${ }^{349}$ Even when the OHA published guidelines purporting to distill, from prior decisions, principles for predictimg how it would decide future exceptions applications, most of the principles remained almost as indeterminate as the statutory criteria themselves. Other principles simply restated all of the facts of earlier cases without indicating whicll facts were determinative or how the OHA would weigh different decision factors in the future. 350 The guidelines also failed to clarify what particular remedy the OHA would grant once an exception was allowed. ${ }^{351}$

The OHA's indetermmate equitable standards, then, left its discretion largely unfettered, especially in "serious inequity" cases. Although its decisions were typically well-written and teclinically proficient, the equitable premises from which its reasoning proceeded remained largely undefined. This undermined essential discipline and control over its decisions, sometimes even causing observers who generally admired the OHA's work to view decisions as arbitrary and ad hoc. This is not to suggest, of course, that equity adjudication can or should be as predictable and principled as rule application. If such predictability were possible and desirable, rules would probably be preferable to adjudication as a decision mode. ${ }^{352}$ The point, rather, is that the OHA's decisions were often less predictable and principled than even equitable adjudication needed to be. ${ }^{353}$

348. 42 U.S.C. $\$ 7194$ (Supp. V 1981).

349. Occasionally, the OHA clarified its equitable criteria with considerable specificity. For examples, see supra notes 167-69 and accompanying text (the Delta-Beacon standard).

350. See, e.g., Ashland Oil, Inc., Gulf Oil Corp. [9 DOE] ENERGY MGMT. (CCH) If 81,058 (July 19, 1982)(description of "gross inequity" criteria).

351. See infra note 380.

352. Of course, predictability is only one relevant factor. See Diver, supra note 10, at 71-79.

353. Here, one may contrast the OHA's approach to that of the old Office of Price Admimistration, which refused to grant an exception unless its rationale was already embodied in a general standard; if that standard were met, however, relief would be granted as a matter of right. Interview with David Ginsberg, formerly of the OPA (July 21, 1982). 


\section{E. Innovative Procedures.}

The DOE Act requires the Secretary to establisl, by rule, procedures for seeking exceptions relief. ${ }^{354}$ It also makes the APA applicable to "any rule or regulation, or any order having the applicability and effect of a rule" as defined by the APA, ${ }^{355}$ and imposes certain additional procedural requirements for such rules, regulations, or orders. ${ }^{356}$ The courts, lowever, have lield that the OHA's exceptions decisions do not have "the applicability and effect of a rule."357 Such decisions are not required by statute to be "on the record after opportunity for an agency hearing" and thus do not trigger the APA's formal procedural requirements. ${ }^{358}$ Neither the APA nor specific energy statutes prescribes or even constrains the procedures for exceptions adjudications. The OHA has exploited this latitude by devising procedures that may be urique among federal agencies, procedures that are botli a source of administrative effectiveness and a cause for concern.

Today, ${ }^{359}$ a firm that desires exceptions relief must file an application with the OHA containing "all relevant facts" and legal authorities supporting relief; a hearing may be requested. The applicant must provide notice to anyone "wlio is reasonably ascertamable by the applicant as a person who will be aggrieved" by the relief sought, unless such notice would be "impracticable." 360 The DOE must notify anyone else whom it can identify as potentially aggrieved. Those notified may file written comments on the application. The OHA then investigates the application. It may solicit information from third parties so long as the applicant has an opportumity to respond, and it "may consider any other source of inforination." 361 At this stage, there are no restrictions

354. 42 U.S.C. $\$ 7194(a)$ (Supp. V 1981).

355. 42 U.S.C. $\$ 7191$ (a)(1) (Supp. V 1981).

356. This has been the case even when those exceptions decisions are actually indistinguishable froin rules, as they often have been.

357. 42 U.S.C. $\$ 7191$ (b)-(g) (Supp. V 1981).

358. United States v. Florida E.C. Ry., 410 U.S. 224, 241 (1973).

359. The exceptions procedures issued as the Office of Exceptions and Appeals was forming in October 1974 remained largely unchanged up to the formation of the DOE in late 1977. Regulations prescribed requirements for notice, applications for exceptions and OEA orders, and appeals within the OEA, but provided little else. 39 Fed. Reg. 35,489 (1974). After the DOE Act lodged appellate review over exceptions decisions in the FERC, see supra note 343, the OHA responded by instituting a two-step, quasi-appellate "Proposed Decision and Order/Final Decision and Order" process, as well as additional procedural accoutrements tbat now characterize the exceptions process and that are summarized in the text. 44 Fed. Reg. 16,887 (1979). These include, among other things, prohibitions on ex parte contacts, discovery procedures, provisions for different kinds of hearings, comment procedures, and temporary and interim orders.

360. 44 Fed. Reg. 16,886-88 (1979).

361. See id. at 16,890 . 
whatsoever on ex parte communications. ${ }^{362}$ After completing its investigation, the OHA ordinarily issues a Proposed Decision and Order (PD\&O) on the application, publishing the substance of the decision in the Federal Register and inviting the public to file notices of objection (in the case of those "aggrieved") or of imtent to participate (for those not "aggrieved" but wanting to participate). If no such notices are filed, the PD\&O becomes final.

If objections are filed, the OHA compiles an official service list, including additional participants (who may be required to employ a lead or common counsel). A party or participant that wishes to conduct discovery on disputed inaterial facts then files a Motion for Evidentiary Proceeding. ${ }^{363}$ If the OHA grants an evidentiary hearing, the presiding officer may require only affidavit or documentary evidence, or otherwise limit the quantity and form of evidence. After all issues have been delineated and written materials submitted, the OHA may conduct a hearing for purposes of oral argument only; here, as in OHA proceedings generally, the presiding officer enjoys broad discretion to control all aspects of the argument. Once a PD\&O is issued, the OHA may grant interim relief pending a Final Decision and Order (FD\&O) with a statement of factual and legal basis. ${ }^{364}$ Appeals froin a denial of exceptions relief must be taken to the FERC in order to exhaust administrative remedies. ${ }^{365}$

Two of the OHA's greatest adıninistrative strengths-its ability to process a large caseload and to decide important cases quickly-directly reflect the informality of its procedures. Until the motor gasoline crisis of 1978-1979,366 the OHA managed to avoid significant case backlogs, and its decisions were generally regarded by the Washington energy bar as being of high professional and intellectual quality. As

362. Ex parte communications between a party or participant and relevant OHA officials are not limited until the PD\&O is issued. Thereafter, such communications are prohibited, but the prohibition does not cover requests for status reports, inquiries as to procedures, or submissions of confidential data under the appropriate rule. If prohibited communications occur, the OHA must make their substance public, notify all participants, and may take other remedial action.

363. OHA procedures prescribe a hierarchy of evidentiary methods-the most preferred being the submission of written materials, then written interrogatories, then depositions, and then evidentiary hearings-and the party or participant seeking the information bears the burden of justifying use of a less preferred method. The OHA may summarily deny such a motion if it is insufficiently specific, unduly burdensome, or would cause undue delay. Procedures for obtaining and protecting confidential information are also provided. OHA decisions on evidentiary matters are interlocutory and are appealable only with the Final Decision and Order (FD\&O).

364. The OHA may issue an FD\&O without first having issued a PD\&O.

365. The FERC has construed its appellate jurisdiction over OHA orders quite narrowly. See infra note 403 and accompanying text. The OHA may issue tenuporary stays pending appeal and may entertain requests to modify or rescind previous DOE orders.

366. See supra notes $268-326$ and accompanying text. 
the Union, Ashland, and Ohio Independents case studies indicate, the OHA was capable of providing immediate relief whenever it appeared that delay would be tantamount to denial. ${ }^{367}$ In a federal establishment in which cases of no greater complexity and policy significance can take years to decide, the OHA's expedition and decisiveness are undeniable achievements widely admired even by those who disagree with the merits of particular decisions.

But the procedural coin has a second side. The OHA's procedures have also occasioned bitter, persistent criticism among many lawyers who practice before the agency. ${ }^{368}$ Although dissatisfaction generally centers on the summary, informal nature of these procedures, nine aspects of OHA procedure have engendered particular criticism. These relate to: notice; discovery; ex parte contacts; cross-examination; lawyers' testimony; interim relief; mixture of functions; the system of internal DOE review; and consumer participation.

Before examining some of these aspects of OHA procedure, several important contextual factors common to all should be mentioned. First, the OHA's procedures were premised upon a continuing state of emergency, a situation in which relief often inust be granted immediately if it is to be effective at all. Although reasonable people can certainly differ on the questions of the causes, nature, and duration of the emergency, most observers would agree that the particular crisis in which the exceptions process was born did not continue for very long. ${ }^{369}$ Nevertheless, it was not until 1978-1979 that the OHA modified its highly informal procedures to provide the safeguards that the origmal ennergency had arguably rendered impractical. ${ }^{370}$

Second, the appearance of procedural fairness in the exceptions process was especially important. Indeed, it was almost as important as the reality. Voluntary compliance is arguably indispensable to the success of any regulatory program but it was particularly vital for energy controls. A combination of the oil industry's fierce competitiveness and the DOE's weak enforcement ${ }^{371}$ inade cheating a great temptation. In those circumstances, any widespread perception among regulated firms that regulatory decisions were unfair or incompetent could undermine

367. See supra text accompanying note 267 .

368. This is especially true of those whose clients (primarily the major integrated oil companies) tend to oppose exceptions relief.

369. Only the two acute shortages of winter 1973-1974 and spring 1979 clearly qualified as full-fledged emergencies.

370. See generally 10 C.F.R. $\& 205$ (1983).

371. Enforcement was virtually nonexistent in areas such as retail motor gasoline. 
the integrity of the prograin. ${ }^{372}$ Several aspects of OHA procedures created difficulties in this regard. ${ }^{373}$

a. Notice. OHA regulations require some form of party or OHA-initiated notice at all stages of the process to persons potentially "aggrieved" by exceptions relief. ${ }^{374}$ Although ample notice has been provided in most cases, especially those in which a PD\&O is issued, it has sometimes been inadequate at earlier stages, such as the period before interim relief is issued.

Exceptions relief has solnetimes adversely affected firms other than those to whom OHA procedures assured notice. Relief to refiners under the entitleinents program is a striking example. Because purchases of entitlements created a pool of funds available to those who were allowed to sell them, any sale of entitlements meant both that entitlements purchasers must buy a greater amount and that the entitlements sellers could only sell a smaller amount. Thus, while the largest refiners with access to controlled "old oil" were obliged to pay the most, ${ }^{375}$ exceptions relief under this program affected every refiner and its customers to soine degree. In the early stages of OHA's Delta-Beacon small-refiner relief program, notice procedures sometimes failed to take account of even those interests most significantly affected. Occasionally, the major refiners most heavily burdened by the relief neither received formal notice nor otherwise participated in the proceeding. ${ }^{376}$ As the magnitude of Delta-Beacon relief grew, however, the inajors began to participate more regularly and the OHA eventually adopted a policy requiring initial notice to the largest refiners to inform them of general changes in Delta-Beacon standards, such as the Warrior adjustment. ${ }^{377}$

372. This may explain why many local service stations apparently violated motor gasoline pricing and allocation regulations during the regulatory breakdown im the spring of 1979 , when small dealers could be driven out of business long before the DOE managed to get around to granting relief. See supra notes 323-25 and accompanying text.

373. For a more detailed discussion of specific OHA procedures, see P. ScHuck, supra note 50 , at $155-77$.

374. See 10 C.F.R. $\S 205.123$ (1981)(notice to adversely affected parties at temporary exception stage); 10 C.F.R. $\$ 205.53$ (1981)(notice to adversely affected parties at perinanent exception stage); 10 C.F.R. § 205.57 (1981)(publication of proposed decision and order in Federal Register).

375. Exxon, for example, estimated that it had to purchase alnost $10 \%$ of the total entitlements.

376. This was true of Pasco, Inc. and the first round of small-refiner exceptions cases generally. See supra notes $147-57$ and accompanying text.

377. See supra notes 199-201 and accompanying text. Of course, few of the firms receiving actual notice would contest most individual cases; it was not worthwhile for every company to oppose relief in every instance. 
Allocation rules, like the entitlements program, created a zero-sum game im which exceptions relief granted to one party necessarily came at the expense of others. Typically, relief required some firms to divert a portion of their supply of crude oil and refined products to the exceptions applicant, a remedy that could only be accomplished by reducing the allocations supplied to existing customers. Yet the firms actually subsidizing the exceptions relief ordinarily received no formal notice even though the ongoing proceedings endangered thcir own supplies. ${ }^{378}$ Moreover, a later challenge to the validity of relief based upon lack of notice would be difficult to sustain, as even suppliers faced a heavy burden of proof to invalidate an OHA order.

The OHA's remedial innovations also caused occasional notice problems. The notice required by OHA regulations generally extended only to those entities that would be aggrieved by the relief that the applicant had requested. But when the OHA fashioned a different form of relief or relief that affected unexpected entities, ${ }^{379}$ or when its relief affected entities which failed to receive initial notice, those entities might lose any opportunity to present their claims until after the OHA decided the cases. ${ }^{380}$

378. This was the case in the vast majority of the retail service station cases during the motor gasoline crisis.

379. In one case, for example, the OHA directed a company with relatively small and insecure petroleum operations to be a supplier, basing the assignment upon the firm's large toral assets. See Transcript of Proceedings, In re Energy Coop., Inc. Nos. BEE-0508, BES-0508, BEL-0508, BSO-009 (Jan. 18, 1980), at 140-42. Seldom did the OHA explicitly analyze wlyy one firm rather than another should be pressed into remedial service. As the exceptions program developed, however, the OHA grew more sensitive to the notice-of-remedy problem and even ordered the ERA regional offices, which identified potential suppliers in certain kinds of exceptions cases, to provide more adequate notice. See, e.g., Vickers Petroleum Corp., [7 DOE] ENERGY MGMT. (CCH) ף 80,183 (Jan. 27, 1981).

380. This oceurred in the Ashland case. See supra notes $240-47$ and accompanying text. Another case that originated during the 1979 gasoline crisis illustrates the problem of notice concerning remedies. A Missouri gasoline jobber, Onyx Corp., claimed to be suffering severe financial hardship from the high prices charged by its base period suppliers, and sought an OHA order designating a lower-priced base period supplier. The OHA followed a two-step process. First, the OHA decided that the claimed Lardslip in fact existed. Then, the OHA delegated the task of assigning a new supplier to an ERA regional office because of its greater familiarity with prevailing local market conditions (and doubtless because the OHA itself was then suffering from a severe case backlog). Mobil Oil, the eventual supplier, was not notified of the PD\&O in the case or of the accompanymg decision to provide interim relief. Six working days after issuance of the mitial decision by the OHA, the ERA informed Mobil by teleplione that it might have to supply Onyx. When Mobil objected, it was told that it could submit objections concerning the possible assignment to the ERA regional office. The next day, the ERA again telephoned to inform Mobil that it would be the new supplier. The FD\&O directing Mobil to supply Onyx was issued one day later.

Mobil appealed the assignment order to the OHA, claiming inter alia that its inability to contest the origimal exception application, because of lack of notice, violated due process and DOE rules. The OHA rejected Mobil's appeal, pointing to Mobil's notice of the assignment itself, 
Whether absence of notice ever affected substantive rights, of course, is difficult to discern. Generally, OHA officials felt that large companies would not incur harm in such cases even if full restoration of the status quo ante was impossible. The OHA typically assigned large companies to be suppliers either because they had more product available or because their prices were lower. Many firms may have failed to object to assignments or other remedies inade without notice not because the remedy was unobjectionable but because the compames expected the OHA to affirm its own prior decision or because the amounts involved simply did not warrant incurring extensive legal costs. $^{381}$

2. Discovery. The OHA limited parties' discovery rights to minimize costs and delay. ${ }^{382}$ On a few occasions, the OHA permitted discovery when additional information seemed vital to a high quahty

its opportunity to contest it on appeal, and its opportunity to contest the original exception before issuance of the FD\&O. The OHA emphasized, furthermore, that giving prior notice of the exception proceeding would unduly burden the applicant and the DOE:

It would surely be an unduly narrow view of the test which the Supreme Court enunciated in the Eldridge case to require a firm that is requesting urgent exception relief because it is facing the imminent possibility of going out of business to notify each of these fifty supphiers of the pendancy of the exception proceeding. Similarly to place this requirement on the DOE and to accompany it with the further requirement that written and oral comments from each of these fifty firms be considered before any action whatsoever is taken would seriously undermine the exceptions process and jeopardize the realization of the Congressional objectives.

Mobil Oil Corp., [4 DOE] ENergy MGMr. (CCH) If 80,158, at 80,842 (Sept. 21, 1979).

The notion of efficiency implicit in this rejoimder, however, seetns unduly narrow, especially in light of the difficulty, discussed earher, of restoring the status quo ante if the OHA erred in deciding a nonadversarial case. For example, in a similar case in which the OHA ordered the ERA to make a new assignment in an exception proceeding without OHA notice to the eventual supplier, reversal of the assignment order for two of the twelve suppliers did not occur until inore than eight months following the new assignments and five months after they were to take effect. Asliland Oil, [6 DOE] ENERGY MGMT. (CCH) If 82,534 (July 28, 1980). In both Ashland and Onyx, the gasoline shortage that precipitated the exception requests had mostly disappeared by the time the OHA reversed its decision. The OHA, the applicants, and potential suppliers also expended a great deal of time and noney in additional proceedings that might have been unnecessary had notice been available in the mitial proceeding. Further, it is not at all clear that the comments that broader notice might have elicited would, as the OHA feared, "seriously undermine the exceptions process." Potential supphers in most allocation cases tended either not to respond to notice or to respond with very general comments; the additional burden on the OHA from comments, then, would be slight, while the benefits might be significant in cases such as Onyx.

381. Interview with Jack Blum, Independent Gasoline Marketers' Council representative (June 22, 1982). In temporary exceptions cases, shortness of notice, as epitomized in the Ashland proceeding, see supra note 317, occasionally posed problems not unlike those posed by coinplete lack of notice. But $A$ shland was unquestionably an unusual case. In general, the short notice provided before temporary exceptions hearings appears to have been justifiable in hight of regulatory requirements aimed at speedy emergency action.

382. See P. SchUCK, supra note 50, at 164. 
PD\&O. ${ }^{383}$ The OHA realized that even in an emergency requiring an expeditious decision, categorical restrictions on discovery could not always be justified. Even now, discovery of nonconfidential inforination can be made only after a PD\&O issues and objections and responses are filed. The OHA generally has rejected requests for pre-PD\&O discovery. The OHA las, however, permitted pre-PD\&O discovery in two kinds of situations-where the disputed issues may be certam enough to permit the appropriate limits of discovery to be discerned at an early stage, and where demial of early discovery would render the PD\&O itself largely useless. ${ }^{384}$

Both bases for early discovery are potentially broad in scope. They reflect a belated recognition by the OHA that such discovery inay often improve the quality and efficiency of its PD\&O's and that the emergency that arguably necessitated OHA's summary procedures can no longer justify categorical restrictions on discovery. In contrast, the case for limiting discovery at the temporary exception stage, where the need for urgency probably outweiglis the improvement in decisional accuracy that discovery may yield, is more convincing.

3. Ex parte contacts. Before March 1979, the OHA did not prohibit ex parte contacts in exceptions cases. Even today, ex parte contacts are only barred after the OHA issues a PD\&O. Two types of ex parte contacts can occur between the OHA and applicants for exceptions relief. The first type-off-the-record meetings between OHA officials and applicants' representatives-seeins relatively rare. The most notorious example occurred in the $A$ shland case. ${ }^{385}$ The second type of ex parte contact is inore prevalent, perhaps even common. When OHA analysts need more information to coinplete their evaluation of any ap-

383. Id. at $164-65$.

384. See Ashland Oil, Inc., [9 DOE] I 84,002 ENERGY MGMT. (CCH) (1981), where the OHA found that information about accounting techniques that various companies unight have used was essential to establishing whether Ashland had a valid exception request. Id. at 87,012-13. This decision could permit early discovery in any case in which an applicant can show that the information it seeks may be essential to its participation in the exceptions proceeding.

385. See P. ScHUCK, supra note 50, at 166-67. Seven Ashland representatives met with five officials from the OHA, including the Director, before Ashland had even filed an exception application. Although the meeting was not transcribed, Ashland's lawyer later recounted that Ashland informed the OHA about the application it intended to file and discussed such procedural questions as notice and the date of the hearing. Although those present denied that any substantive aspects of the case were discussed, the mere holding of such a meeting, coupled with its off-therecord character and the extraordinary relief that Ashland quickly obtained, created at least the appearance of possible improper influence over the OHA. According to one lawyer experienced in OHA proceedings, such "procedural meetings could be a valuable vehicle for a subtle form of persuasion . . . .; "By turning Mel onto an interesting issue or innovative remedy, which could often be done im such an encoimter," one might increase the probability of even that relief. 
plication, they often teleplione the applicant to request the additional facts. ${ }^{386}$

4. Cross examination. As noted earlier, OHA regulations permitted cross-examination in ordinary exceptions proceedings only if less time-consuming methods of imterrogation (such as requests for documents or written interrogatories) are unavailing and the OHA presiding officer authorizes it. The regulations do not specifically authorize cross-examination in temporary exceptions cases, but the OHA has sometimes permitted it. ${ }^{387}$ Even where permitted, lowever, cross-examination is often less extensive than some parties may wish in temporary exceptions proceedings. In the Ashland temporary exception hearing, attorneys were sometimes limited to one question; in one instance, Goldstein ruled the single question out of order and refused to allow anotleer. ${ }^{388}$ The OHA's procedures on cross-examination, especially in temporary exceptions hearings, also sometimes denied opposing parties much prior notice of an applicant's evidence. ${ }^{389}$ Moreover, the OHA's requirement that the applicant mail a copy of its application to affected parties did not pertain to whatever inforination that applicant deemed confidential. ${ }^{390}$ Without pre-hearing discovery, therefore, an apphicant could subvert effective cross-examination further by retaining essential inforunation as confidential. ${ }^{391}$

For the most part, presiding officers took the place of the crossexaminer, often pursuing lines of questioning that cross-examination would probably have covered. In this imquisitorial role, they attenipted to project the skeptical attitude they felt was necessary in a process

386. During the flood of gasoline retailers' applications in 1979, inany apphications were incomplete and some showed a total misunderstanding of the standards for relief. As a result, the OHA analysts often called applicants to explain the standards and sometimes discussed the merits of the application; written records of the substance of such calls were not always kept. To be sure, the immense case backlog and sense of crisis that then prevailed encouraged, and perhaps even justified, these more informal means for disposing of cases. Yet complaints about such ex parte communications extended to other exceptions decisions as well.

387. See, e.g., Ohio Independents Transcript, supra note 250.

388. Goldstem also ruled that parties could question Ashland only during 10 to 15 minute presentations. Although Goldstein evidently imposed these restrictions in the interest of brevity, his desire to conduct the Ashland hearing in one day rather than two, and the Ohio Independents hearing in less than one, seemed a more important motivation than the inherent urgency of the situation. Even in an emergency, the delay that would have resulted from a somewhat longer hearing was probably imsignificant. See, e.g., In re Ashland Oil Co., Nos. BEE-0373, BEL-0373, \& BSG-0007, at 125-26 (official transcript of proceedimgs).

389. See P. Schuck, supra note 50, at 168-69.

390. See 10 C.F.R. § 205.53(a) (1975).

391. See P. SchuCK, supra note 50, at 169. 
designed to grant rehef only in extraordinary cases. ${ }^{392}$ The parties' opportunity to cross-examine came only after the presiding officer had finished questioning that witness. Although according the presiding officer priority in questioning is not objectionable, the OHA-imposed time limits on attorneys and the parties' imadequate access to information relevant to cross-examination may well have prejudiced some parties, preventing or discouraging them from effectively presenting their arguments. Unfortunately, the magnitude of this risk is difficult to measure.

5. Lawyers' testimony. In OHA hearings, lawyers often testify in lieu of their clients. This practice inay have helped the smaller, less sophisticated applicants, especially gas station owners. A trained lawyer might be able to present a case for rehef nore effectively than a company employee, and a company might find it too costly to send employees to Washington or even to a regional center to testify.

Nevertheless, as a general practice, the substitution entails several difficulties. Outside counsel are unlikely to be as well-inforined in the relevant respects as an applicant's own employees. When, as often happens, no employee even attends the hearing, less inforination, or less rehiable inforination, may be produced. Lawyers' testimony, after all, is hearsay, often double or triple hearsay. They may be misled themselves, inadvertently presenting distorted data out of ignorance or detachment from the operative facts. The infrequency of sworn statements may increase this risk.

6. Interim relief. As Ashland, Ohio Independents, and many retail gasoline allocation cases deinonstrate, the OHA often provided expedited relief to applicants before issuing a PD\&O and, indeed, even before submitting a draft PD\&O for internal departmental review. Such relief was crucial to the effective operation of the exceptions process. ${ }^{393}$ Although decisions erroneously granting temporary relief can in principle be corrected later, the consequences of that relief often can-

392. See, e.g., In re Ashland Oil Co., Nos. BEE-0373, BEL-0373, \& BSG-0007, at 29-56 (offcial transcript of proceedings)(questioning Ashland officials).

393. See supra notes 216-18 and accompanying text. The large number of teinporary exceptions, temporary stays, and interim decisions and orders, particularly as a fraction of the 1305 PD\&O's issued from September 1977 to early May 1982, demonstrates the inportance of such temporary rehef. After the PD\&O procedure was instituted in late 1977, the OHA issucd a total of 411 such temporary exceptions and stays, including relief to 237 gasoline stations. In an even larger number of cases, the OHA provided "standby" relief when it issued a PD\&O, pending its confirmation by a FD\&O. Information supplied by Tom Wiecker, OHA Deputy Director. 
not.394 In practice, temporary rehef, sometimes granted after only the most summary kind of hearing, can be almost tantamount to permanent relief. By the time the FD\&O was issued in Ashland, for example, two and one half years had passed; 395 the Iranian boycott and rapidly escalating crude prices had given way to a worldwide glut and to stable or decliming crude prices. Even though the FD\&O found some of Ashland's rehief to have been improperly granted, the $\$ 5.7$ million in restitution that the OHA finally required Ashland to pay did not alter the fact that Ashland had received the relief it requested when it felt it needed it. Moreover, the OHA's failure to require firms to pay interest on the value of relief granted erroneously and later withdrawn meant that Ashland received what amounted to an enormous interest-free loan. ${ }^{396}$ By failing to require payment of interest on the relief, the OHA prevents restoration of the status quo ante even where the return of the relief itself can somehow be accomplished.

There are additional reasons why interim decisions, even if erroneous, are difficult to correct subsequently. An earlier decision acquires a powerful psychological momentum that may discourage subsequent reversal, especially by the same decisionmaker. It may also engender expectations as well as economic and political commitments that generate compelling new equities, thereby making reversal difficult or even unjust. An entirely different economic universe may have evolved in the interim; remedial solutions necessary to correct the earlier error may no longer be fair, sensible, or workable. Under these circumstances, it doubtless is tempting to uphold, rather than reopen, the original decision.

The tendency of temporary (or indeed final) relief to have irreversible effects is, of course, an mevitable feature of any regulatory system that seeks to address an emergency of only hmited duration. Conversely, the erroneous denial of relief $m$ the midst of an emergency, if it precipitates bankruptcy or other irreparable injury, can never be fully rectified after the fact either. It is likely that many such erroneous denials of relief occurred during the motor gasolime crisis, when the OHA's caseload simply overwhelmed its decisionmaking capacities. ${ }^{397}$

394. Sometimes the OHA reversed its earlier order but did not even attempt to return the erroneously granted relief. See, e.g., Gulf Oil Corp., [9 DOE] ENERGY MGMT. (CCH) ๆ 80,157 (April 21, 1982).

395. See supra notes $245-47$ and accompanying text.

396. In granting Ashland a stay pending appeal of the OHA's final restitution order, the OHA for the first time imposed an interest obligation, running from the date of that order-iwo and a half years after the original FD\&O.

397. See supra notes $323-25$ and accompanying text. 
7. Mixture of functions. In addition to deciding exceptions applications as an original natter, the OHA exercises appellate jurisdiction in several important areas. ${ }^{398}$ The OHA, for example, approves and issues reinedial orders that the ERA proposes and wishes to enforce. ${ }^{399}$

The OHA has managed to retam effective control over the appellate process despite considerable congressional concern with the problem of appeals from OHA exceptions decisions. The Energy Conservation and Production Act of 1976, for exainple, ainended the exceptions authority provided by the EPAA to require that "no review of a denial under this subparagraph shall be controlled by the saine officer denying the adjustment pursuant to this subparagraph."400 The OHA easily neutralized this requireinent by assigning appellate review of exceptions decisions to different OHA staff nuembers than those who wrote the decisions. In the Departinent of Energy Organization Act, Congress again attempted to assure independent appellate review by requiring that exceptions decisions be appealed to the FERC.401 Again, the OHA made external review more difficult and remote by instituting the two-step procedure of a PD\&O, then a FD\&O. This interposed what ainounted to an additional appellate layer through which aggrieved parties inust pass on their way to FERC review.

Quite apart from the OHA's inaneuvers, however, neither the FERC nor the TECA has typically used its appellate jurisdiction to control the exceptions process. The TECA has accorded exceptions decisions conspicuous deference, einphasizing the coinplexity of the industry and the need for flexibility and expert analysis. ${ }^{402}$ The FERC, in a judicially approved construction of its statutory review authority, has declined to review grants of exceptions applications. ${ }^{403}$

A second mixture-of-functions problem concerns the coinbination of the OHA's exceptions jurisdiction with its appellate jurisdiction over

398. See 10 C.F.R. $\$ 205.100$ (1982).

399. See 10 C.F.R. $\$ 205.190-205.199 \mathrm{~J}$ (1982). This study does not analyze or discuss the OHA's appellate activities, except insofar as they have created potential sources of procedural unfairness with respect to the OHA's exceptions jurisdiction. See, e.g., Aman, Institutionalizing the Energy Crisis: Some Structural and Procedural Lessons, 65 CoRnell L. Rev. 491 (1980)(containing analysis of OHA appellate activity).

400. Energy Conservation and Production Act, 90 Stat. 1125, 1128 (1976)(codified at 15 U.S.C. § 766(b) (1982)); see also Aman, supra note 399, at 551-63.

401. See supra notes $343-44$ and accompanying text.

402. See, e.g., Pasco v. FEA, 525 F.2d 1391, 1404 (Temp. Emer. Ct. App. 1975). But see Husky Oil Co. v. DOE, 582 F.2d 644, 653 (Temp. Emer. Ct. App. 1978)(denial of application held to be arbitrary, capricious, and discrimmatory).

403. See Texaco, Inc. v. DOE, 663 F.2d 158, 167-68 (D.C. Cir. 1980). The shift toward this position began as early as Lunday-Thagard Oil Co., No. RA78-1 (F.E.R.C. Nov. 16, 1979). 
remedial and enforcement orders by other DOE offices. Uniting these functions compels the OHA to perform fundainentally inconsistent roles. In exceptions matters, the OHA is expected to coordinate its decisions closely with the ERA and other policy and enforcement arms of the DOE through informal discussions and through the more regularized departmental review structure. But when it sits to review proposed remedial and enforcement orders of the ERA and other offices, the OHA is no longer the consulting colleague but rather must play the detached, independent judge evaluating the arguments of prosecutors. In the appellate review context, each actor is bound by strict limitations on ex parte communications with the other. The OHA has sometimes violated these limitations. ${ }^{404}$

Indeed, the OHA might be obliged to decide the same legal question twice, once while wearing its consultative policymaker hat and once while wearing its independent adjudicator hat. For example, the OHA was called upon to review the legality of the ERA's interpretation of the status of refiner processing agreements under the entitlements program as a remedial and enforcement matter. ${ }^{405}$ There, the ERA was simply an advocate pleading its case to the OHA, the neutral judge. But the OHA decided the same issue in formulating its DeltaBeacon standards for small-refiner relief. ${ }^{406}$ There, it sat on the saine side of the table as the ERA, its regulatory colleague.

8. Administrative review committee. The problems associated with the internal departmental review committee-particularly its inability to act as a check on OHA decisions and on the DOE's refusal to divulge the grounds for altering previously rendered decisions-have been discussed above. 407

9. Consumer participation. The adversary process in exceptions cases may sometimes have been inadequate to develop a full record and to discipline the OHA's decisions because firms had little reason to resist exceptions rehef granted to suppliers when they could pass the resultimg costs along to consumers. Yet involveinent by consuiner-ori-

404. See, e.g., Gulf Oil Corp. v. United States Department of Energy, 663 F.2d 296, 302-03 (D.C. Cir. 1981).

405. See, e.g., Phillips Petroleum Co., [1976-1977 Transfer Binder] EnERgY MGMT. (CCH) đ 87,008 (Jan. 19, 1977)(petition for special redress concerning ERA enforcement action).

406. See supra notes $153-205$ and accompanying text.

407. The problems associated with the internal departmental review committee-particularly its mability to act as a check on OHA decisions and on the DOE's refusal to divulge the grounds for altering previously rendered decisions-have been discussed earlier. See supra notes 135-39 and accompanying text; see also Colonial Oil Co., [1 DOE] ENERGY MGMT. (CCH) ๆ 82,519 (Dec. 21, 1977). 
ented organizations in exceptions proceedings was rare. State government representatives participated in isolated instances, such as in the Ashland proceeding, but direct representation by a consumer organization occurred only once. In 1976, when several large refiners sought a class exception that would allow them to pass $\$ 1.3$ billion through in increased nonproduct costs, the Consumers Union filed a Petition for Special Redress seeking appointment of publicly financed representatives for consumers in the proceeding. The FEA, granting the petition, published a Federal Register notice that invited consumer representatives to intervene and offered such groups financial assistance to do so. 408 The Consumers Union applied, was accepted, and participated in both the proceeding and the court case that stayed the grant of the class exception..$^{409}$

After 1978, Congress effectively eliminated participation by nonindustry groups altogether when it ruled out public funding for intervenors like the Consumers Union. 410 But it is difficult to say whether and to what extent a higher level of participation in DOE rulemaking by nonindustry groups would have enhanced the quality of that process. First, inost exceptions proceedings were quite narrow in focus and impact; consumer participation in such proceedings might not have been worth the cost. Furthermore, when an individual exceptions case had significant public interest ramifications, an adversary relationship would sometimes develop between different segments of the industry; conflicting interests among companies could have the effect of indirectly representing consumers' interests. The major integrated companies, for example, often found themselves arguing agamst excessive subsidies to small refiners, while the small refiners based their claims for protection partly on the lower consumer prices they said would result from increased competition in the industry. Fimally, Goldstem and the OHA staff claim to have made a conscientious effort to

408. 41 Fed. Reg. 33,282 (1976).

409. In June 1979, three months after the rehearing in the court case was denied, Consumers Union applied for $\$ 14,469.35$ in attorney's fees for its role in the hearing before the OHA. The OHA, citing the low fees requested and the pro bono participation by Consumers Union in the court procecdings and other aspects of the case, granted the request in full. Consumers Union, [6 DOE] ENERGY MGMT. (CCH) I 82,555 (Scpt. 19, 1980). The potential effect of this enormous cost pass-through on consumcr prices, and wholesalers' and retailers' wcak incentives to contest it, persuaded the FEA that adversarial intervention by a consumer group was justified. Most other exceptions cases, however, involved fewer refiners and a less direct econoinic effect on consumers. This fact, along with the technical complexity of nost issues in exceptions cases, discouraged participation by nonindustry groups.

410. See 1980 Fiscal Year Appropriations Bill for Energy and Water Development $\S 103$, Pub. L. No. 96-69, 93 Stat. 441 (1980). 
take into account the interests of consumers in exceptions proceedings, even when no consuiner groups participated.

\section{F. Latent Functions: The Exceptions Process as Safety Valve.}

The OHA's exceptions process exemplifies an observation made in a celebrated book by sociologist Robert Merton, in which he contrasted what he called the "manifest and latent functions" of a sociological systein. To Merton, a mamifest function consists of the objective consequences of a system that "contribute to its adjustment or adaptation and were so intended."411 A latent function consists of the system's "unintended and unrecognized consequences." 412 The OHA exceptions process exhibits a number of functions, some inore latent than inanifest, whose common feature is that they operate as "safety valves" in the regulatory system. To evaluate fully the operation and significance of the exceptions process, we must understand the pressures that inake such safety valves seem necessary, how these devices work to relieve those pressures, and what new problems they create for the regulatory system.

The safety valve metaphor is quite general; it does not specify the kinds of pressures that it is designed to ease. Conventionally understood, the exceptions process eases the demands for equity generated by special hardships or unforeseen circuinstances. That is what the late Judge Harold Leventhal evidently had in mind when he called it "an essential safety valve of the regulatory process." 413 The federal courts have sometimes regarded the existence of such a safety valve as a factor relevant to, although not necessarily determinative of, the validity of general rules. ${ }^{414}$

Exceptions for hardship and unforeseen circumstances constitute the "bread and butter" of the DOE exceptions process, surely accounting for the vast majority of the OHA's decisions. ${ }^{415}$ Such relief, which corresponds to Aman's "fairness" and "hardship" exceptions, 416 performs important safety valve functions. By reducing the hardships and the sense of injustice suffered by those to whom a rule apphes, exceptions diminish the pressure to challenge the rule itself. But this equita-

\footnotetext{
411. R. Merton, Social Theory and Social Structure 19, 63 (1957).

412. Id. at 63 .

413. Leventhal, Principled Fairness and Regulatory Urgency, 25 CASE W. RES. L. REv. 66, 77 (1974).

414. Indeed, two Justices of the Supreme Court were evidently prepared to hold that an agency must provide an exceptions process if its general rules are to be upheld. FCC v. WNCN Listeners' Guild, 450 U.S. 582, 604 (1981)(Marshall, Brennan, J.J., dissenting).

415. Interview with Tom Wiecker, OHA Deputy Director (June 18, 1982).

416. See supra text accompanying note 71 .
} 
ble safety valve function entails risks and problems. Judge Leventhal characterized one of them this way:

Care must be taken that the rule be proved and not swallowed by the exception. . . . A safety valve is one thing, a dissipation of all force another. Care must also be taken lest [exceptions] be granted waywardly and willy-nilly, justified by little more than the exigencies or protests of the day. ${ }^{417}$

By all accounts, the OHA did not grant exceptions rehef "willy-nilly." In its early years, the OHA applied what several observers described as a "tombstone" standard for relief; a firm could not hope for an exception unless it was on the verge of going out of business. Even later on, when the exigencies of the original crisis abated somewhat and the OHA seemed to relax its application of this standard, applicants were obliged to overcome a heavy presumption against rehef. ${ }^{418}$ Only during the motor gasoline shortages of 1978-1979 did the OHA seein to grant relief "at wholesale," as it were. When this occurred, Leventhal's warning proved prescient. 419

Just as the limits of rules, the hardships and aberrations they produce, represent only one set of reasons for which agencies seek regulatory equity, ${ }^{420}$ so the need for equity is only the inost obvious of the safety valve functions that the exceptions process performs. For exainple, the OHA has also provided DOE prograin administrators with safety valves of a political and bureaucratic nature, and these threaten administrative law values far inore than the mere pursuit of equity in the application of rules.

In the politically overheated atmosphere of energy policy during the 1970's, top energy officials found in the OHA the cooling breeze that they so desperately needed. "Leave it to Mel!" came to be the watchword of harried officials looking for a quick fix; it was a liberating device for policymakers who felt shackled by legal and political constraints. The roots of this strategy can be traced to Congress. From the beginning, Congress regarded a flexible exceptions process as a politically and programmatically essential component of a viable system of energy price and allocation controls. All of the legislation authorizing energy regulation, froin the origmal Economic Stabilization Act through the DOE Act, provided for the granting of discretionary exceptions. Indeed, it is possible, although difficult to demonstrate, that

417. Leventhal, supra note 413 , at 78.

418. See Gasoline Hearings, supra note 291, at 64 (27.5\% approval rate for exception relief during crisis).

419. See supra notes 322-24 and accompanying text; see also Comment supra note 6, at 1154 57.

420. See supra Part I. 
these laws would never have been enacted had not such a process been provided. 421

To energy administrators, the exceptions process was equally essential. When congressional and industry coinplaints about the breadth, rigidity, and categorical nature of controversial energy regulations grew bitter, energy officials could often defuse this opposition by einphasizing that an exceptions process, capable of producing the desired flexibility, was available to handle any difficulties that inight arise. As in Ashland, White House staff members or departmental leaders would sometimes urge powerful opponents of particular rules to apply for exceptions rehef; indeed, they inight even alert OHA Director Goldstein that applications would soon be forthcoming. When the OHA did grant an exception, as in Ashland, the opponents would no longer have to invest political capital in seeking changes in the rules theinselves.

This tactic of encouraging opponents to seek an exception deflected inuch potential pressure from the DOE's political appomtees to the OHA's civil servants. Because the deflected pressure could not be brought to bear effectively against the $\mathrm{OHA}$, much of it was dissipated. Witli great skill, Goldstein managed to insulate his agency from dayto-day congressional influence. During the gasoline crisis im 1979, the OHA had three full-time employees responding to case inquiries from congressional offices. Goldstein and a deputy personally handled all direct calls from senators or representatives about pending cases and successfully fobbed them off by einphasizing the adjudicatory nature of the proceedings and the risk to all concerned of even an appearance of outside pressure on the tribunal. ${ }^{422}$ Here as elsewhere, ${ }^{423}$ Goldstem was able to draw upon the mystique, etlios, and traditions of judicial autonomy to assure the OHA broad operating freedom. By wrapping the OHA im the adjudicatory mantle, lie could obscure the fact that the OHA was deeply immersed im the design and implementation of controversial regulatory policy. This cannouflage promoted the OHA's own bureaucratic interests. More importantly, however, it insulated the DOE's political leadership from some potential criticism and pressure.

The exceptions process created other bureaucratic safety valves for the Department. First, it seemed to relieve some administrative pres-

421. For a somewhat similar inquiry, see the Supreme Court's discussions of the severability issue in Immigration and Naturalization Serv. v. Clradha, 103 S. Ct. 2764, 2774-76 (1983).

422. Interview with Melvin Goldstein (June 3, 1982).

423. See supra note 342 and accompanying text (Goldstein persuading the Secretary to grant the OHA admimistrative independence from the ERA). 
sures created by the ERA, a regulatory apparatus that simply was not equal to its awesome statutory responsibilities. Even those who ran the ERA readily acknowledged its dispirited and mediocre staff, sluggish procedures, inadequate information base, stalemated political and bureaucratic interests, and chronic indecision. ${ }^{424}$ We have seen that even under the best of circumstances, controversial ruleinaking has become a protracted, tortured process. At the ERA, adopting new rules or improving old ones within a policy-relevant time frame was always probleinatic, sometimes impossible.

To the leadership of the Department, the OHA presented a dramatic contrast to the ERA's administrative morass. ${ }^{425}$ The OHA produced data and documents quickly, professionally, and efficiently. The staff, painstakingly recruited, selected, and trained by Goldstein, enjoyed an unusually high esprit de corps, a sense of influence, umssion, and widely acknowledged excellence. The OHA's procedures facilitated swift case processing and decisions. Because the OHA lacked any programmatic responsibility, processed only individual cases (albeit often important ones), and was relatively insulated from external pressures, inany political and administrative constraints that hobble and distract operating agencies like the ERA did not apply to the OHA. Unlike the ERA leadership, Goldstein was not obliged to spend most of his time testifying before Congress, meeting with outside groups, running a large bureaucracy, or conferring with the Secretary and Deputy Secretary. His only job was to "move the caseload," a task that remained quite manageable until the motor gasoline crisis.

Under these circuinstances, the DOE's leaders were all too eager for the OHA to fill the regulatory vacuum that the ERA's ineptitude and paralysis had created. In the long run, however, the exceptions process became a fig leaf concealing the incoinpetence, indecision, and political weakness of the DOE's regulatory apparatus. The OHA was forced to assume broad policynaking responsibilities for which it was not particularly well suited, and the DOE was diverted from making more fundannental administrative and policy changes.

The tactic of deferring to the OHA, of course, did not always succeed. When the DOE first imposed the allocation regulations in 1974, for example, complaints of hardship and inequity flooded the agency. When firms deinanded a flexible, low-cost process that could grant prompt relief, they were usually directed to the exceptions office, where

424. Interview with Hazel Rollins, supra note 233; interview with David Bardin, supra note 347; interview with John O'Leary, supra note 137.

425. Interview with Hazel Rollins, supra note 233; interview with David Bardin, stpra note 347; interview with John O'Leary, supra note 137. 
they were often disappointed. The exceptions office in those days had developed very stringent standards for relief, sluggish procedures, and an attitude toward apphicants that even some energy officials characterized as adversarial, unresponsive, and accusatory. Fearful that its safety valve was jammed and that industry cooperation was being jeopardized, the energy agency created an internal administrative review committee designed to conforn exceptions decisions to the agency's larger policy purposes. ${ }^{426}$

Once the initial shock of the Arab oil embargo abated and the entitlements program was implemented, however, the exceptions process evolved into a more flexible, responsive, and efficient instrument. As the earlier case studies suggest, the exceptions process began to transcend its safety valve functions, designing the specifications of the very regulatory system whose pressures it was supposed to relieve. At this point, certain subtle dangers implicit in its safety valve role began to materialize.

Safety valves, after all, can sometimes function too well. By relieving pressures upon a system, they can make the system appear to be performing better than it actually is. This fosters the illusion that all is well. Indeed, safety valves can tempt those who operate the systein to forget that the pressures exist at all. The operators may then ignore the conditions that generated those pressures until the safety valve's capacity is exceeded and the system is overwhelmed. The OHA safety valve had precisely this effect, encouraging the DOE to neglect or defer fundamental policy problems that it ought to have confronted and resolved. By undertaking the Delta-Beacon adjudications, for example, the OHA relieved the DOE of the necessity to develop a long-run strategy for dealing with the competitive problems of small refiners. Had the DOE addressed the problein systematically instead of in case-bycase adjudications, the Department might have been inclined to ask a broader set of questions and to analyze a inore comprehensive set of impacts. In principle, of course, the exceptions process could have been broadened imto a kind of rulemaking proceeding similar to those conducted by the ERA. In practice, however, the exceptions process created a context and a psychology likely to affect decisions in subtle but important ways. OHA cases tended to focus attention upon hardship suffered by the individual firm before it, rather than upon effects on the industry as a whole or on consuners generally. Even groups of exceptions cases would tend to deal more with what one official aptly

426. Within several years, however, Goldstein managed to disarm this control device. See supra notes $135-39$ and accoinpanying text. 
called "the average anomaly" than with the typical situation. For example, the OHA never really addressed the question of the competitive effects of Delta-Beacon relief upon those small refiners who did not qualify under the OHA's criteria. ${ }^{427}$ Even an agency as beleaguered as the ERA probably could not have avoided that basic policy issue for so long had it been obliged to confront it in the context of a rulemaking proceeding.

By deflecting the modest pressures that were generated under "normal" conditions, the OHA safety valve also helped to conceal fundamental problems in the systein of notor gasoline allocations when unusual stress finally exposed the gravity and extent of these problems. Thus, in the Iranian convulsions of 1978-1979, the ERA could not deal effectively with the shortage, while the OHA was utterly inundated by a massive caseload generated by the ERA's anachronistic rules and aborted rulemaking. As a result, the allocation system simply broke down. The strategy of "leave it to Mel," ordinarily quite workable, had actually incapacitated the systein from coping with extraordinary demands. In a functional transformation for which the system was wholly unprepared, the OHA safety valve became a floodgate.

One more safety valve function that the OHA performed deserves mention. In addition to encouraging policymakers to avoid the timeconsuming and politically hazardous tasks of strengthening and rationalizing the DOE's rules, the exceptions process also affected the kinds of rules that policymakers ultimately and belatedly wrote. Knowing that the OHA was there to dispense situational justice, the ERA could formulate general rules without having to think through fully their effects on individual firms or classes of firms. An example was the 1974 rule elimmating adjustments in the base period allocations to service stations. ${ }^{428}$ In the rule's preamble, the ERA acknowledged that its breadth could create difficulties for some stations but casually dismissed that problem on the ground that exceptions relief would be available to handle such cases. Once the 1979 motor gasoline shortage occurred, however, the rule, along with many others issued in the same

427. See supra note 204 and accompanying text. Similarly, a study of the FCC's regulation of cable television found both that the Commission's granting of imdividual waivers to its "distant signal" rule tended to blind it to the significant policy impact of these waivers in the aggregate, and that the Cable Bureau used that tendency to influence policy through the manipulation of the waiver process. See R. Berner, Constraints on the Regulatory Process: A Case Study of Regulations of Cable Television 21-22 (1976).

A federal court has faulted the Federal Aviation Administration on much the same ground. See Delta Air Lines v. United States, 490 F. Supp. 907, 916 (N.D. Ga. 1980)(discussed in Comment, supra note 1, at 1138-40).

428. See supra note 274 and accompanying text. 
short period, generated so many hardship and inequity cases that the OHA was overwhelmed and could not provide timely and effective relief. ${ }^{429}$

In sum, the OHA performed many different safety valve functions, some of which were almost certainly unforeseen when the exceptions process was created. Each of these functions was a mixed blessing for the regulatory system as a whole. Indeed, the more effectively this safety valve performed, the more it encouraged energy pohcymakers to rely upon it rather than making necessary improvements in other parts of the system. This led to a self-reinforcing dynamic of incapacity in which more and more of the difficult political choices were made by relatively detached adjudicators who were ill-equipped to make them. At the same time, those policymaking organs with front-line responsibilities were permitted to withdraw and to atrophy.

Short-terin pressures made reliance on the exceptions process an attractive expedient. In the long run, however, this arrangement probably weakened the regulatory process. Few officials, however, anticipated that there would be a long run as far as petroleum price and allocation regulations were concerned. Almost all officials expected that whatever had been done could be readily undone and that any errors would soon be rendered irrelevant by the termination of controls. ${ }^{430}$ The significance of this delusive anticipation of imminent deregulation can scarcely be exaggerated. It shaped everything that the energy agency did and did not do and the priorities that the agency set. But the demands placed upon the exceptions process also reflected both a false sense of security and a credulous belief that all was well, illusions that safety valves can encourage in people struggling with coinplexity and uncertainty.

\section{CONCLUSION}

It is now possible to offer some answers to the questions about the relationship between the exceptions process and regulatory equity posed at the end of Part I, and to see what ineaning can be derived for future administrative design. In the nature of this study, these answers must be tentative, quahtative, and in some cases impressionistic. Moreover, it remains an open question whether and to what extent they can be generalized beyond the kind of regulatory prograin and exceptions process that the DOE administered. What follows, then, should be re-

429. See supra notes $323-25$ and accompanying text.

430. See, e.g., Interview with Frank Zarb, former FEA Administrator (July 28, 1982). 
garded as only a first step toward a better understanding of that relationship.

In evaluating the OHA exceptions process and assessing its relevance to the pursuit of regulatory equity in other regulatory settings, three distinctive aspects of the OHA's situation must be borne in mind. First, the OHA purported to inake many (though certainly not all) of its decisions under emergency conditions in which expedited decision procedures were thought to be essential and certain external checks, such as rigorous judicial and congressional review, were unavailable as a practical matter. Second, the DOE expected the OHA not simply to achieve regulatory equity, but to help shape a regulatory program of unusual complexity and comprehensiveness. Consequently, the OHA had to operate not on the peripliery of regulatory policy but at its very center. The DOE often used the OHA to supplant, not simply to augment, a rulemaking apparatus that appeared to be singularly ineffective. Hence, its policy role was thrust upon it by others, even as it energetically arrogated that role to itself. Finally, the OHA was administered by an unusually experienced and able director, one in whom the DOE's leaders reposed enormous trust. Certam administrative practices that worked tolerably well under Goldstem's administration might, under other leadership and in other circumstances, occasion serious difficulties.

\section{A. The Problem of Functional Integration.}

DOE exceptions decisionmaking clearly did not confine itself to the conventional goal of such processes-the pursuit of situational justice im particular cases. Instead, the exceptions process constituted a central element, and occasionally the central element, of the agency's policymaking apparatus. For many reasons, soine more defensible than others, the DOE's leaders delegated to the OHA sweeping discretion and mitiative in developing, implementing, and reformmg soine of the DOE's most important policies, discretion that the OHA aggressively claimed. The direct subsidization of many small refiners and the allocation of ANS crude are among the examples most prommently discussed in this article. These policymaking mitiatives by the OHA often took the form, not of equitable criteria, but of what amounted to legislative-type rulemaking.

In general, the OHA managed to perform these broad policy functions without impairing its ability to respond to particular clains of situation-specific mjustice. Indeed, the vast majority of its exceptions decisions involved hardship claims of this type, claims having few if any implications for DOE policy generally. It was only during the mo- 
tor gasoline crisis of 1979, when the ERA's regulatory failures overwhelined the OHA with myriad hardship claims and related policymaking burdens, that the OHA's ability to dispense regulatory equity was significantly impaired. In this respect, at least, the evidence from the case studies strongly suggests that the mixture of policymaking and equitable functions in one agency was not inherently problematic. Instead, it became problematic only when imcompetent policy development and sluggish rulemaking unleashed an avalanche of hardship cases that exceeded the administrative capacities of the exceptions process.

\section{B. The Problem of Organizational Integration.}

As a matter of formal organizational structure, OHA exceptions decisions and ERA rulemaking were fully integrated. The directors of both units reported to the Secretary and Deputy Secretary of Energy, who were supposed to coordinate the two functions. In practice, however, the OHA and the ERA remained bureaucratically separate to a pronounced degree. The OHA was run with little guidance froin or involvement by DOE's politically accountable leadership. Goldstein regarded this autonomy as essential to the OHA's reputation for independent judgment and fairness, and even insisted upon it as a condition of his contimued employment. The Secretary and Deputy Secretary seein to have agreed with his assessinent.

This separation had sigmificant effects upon the character of both processes. As the case studies reveal, coordination between the OHA and the ERA was often poor. The exceptions process should have been used by the ERA to obtain rapid feedback about the unanticipated consequences of its rules. Instead, the exceptions process was used to perform functions that a more effcctive rulemaking process would have discharged itself. Some of the OHA's decisions seeined detached and remote from the operational, administrative, and programmatic factors to which the ERA was institutionally sensitive. ${ }^{431}$ Moreover, the DOE's promiscuous use of exceptions as an all-purpose "safety valve" probably weakened the ERA, though in an attempt to leelp it. The DOE was able to put off the hard political and bureaucratic choices needed to rehabilitate the ERA as an effective policy instrument.

It is not at all clear that a greater structural integration of the OHA and the ERA would have produced "better" policies and decisions by

431. An example of this is the Ohio Independents ruling and the 1979 class exception implementing the "unusual growth" adjustment. Professor Strauss found in the Department of the Interior an even more pronounced isolation of policy-relevant adjudicators from officials with policy responsibility, with similarly problematic results. See Strauss, supra note 70, at 1254-64. 
each. First, permitting the same official to administer the rulemaking process and to decide exceptions cases might simply lead to a new separation within that official's umit. The advantages of specialized functions, after all, can only be realized by developing different kinds of personnel, operating procedures, performance criteria, and professional-technical skills. Even within a single agency, such differentiations are likely to fragment the organization in ways similar to those that made the integration of the OHA and the ERA so problematic. There are severe limits to the ability of structural reorganization to transcend differences that are deeply rooted in specialized functions, perspectives, operating routines, and training.

Second, informal devices for bridging the structural separation between the OHA and the ERA were readily available. ${ }^{432}$ If they were not used effectively, if the well-defined personalities and political dynamics in the DOE policy process neutralized their effects, it is difficult to behieve that formal changes alone would have much altered that process or its outcomes.

On the other hand, separation did have some important benefits, especially for the exceptions process, that at least partly offset the disadvantages. Public acceptance of the OHA's more far-reaching exceptions decisions, for example, may have been enhanced by its structural independence, which strengthened its claim to be engaged in an essentially adjudicatory, nonpolitical process. As suggested earlier, this claim was grossly exaggerated in those cases, such as Delta-Beacon, in which the OHA was essentially making legislative policy. Even then, however, there was always something to the claim. ${ }^{433}$ In fact, the OHA was relatively free of the political, bureaucratic, and programmatic pressures that shaped (and impeded) decisions in other parts of the DOE. In a situation in which the reform of energy pohicy seemed paralyzed by political deadlock, the OHA's relative independence doubtless facilitated movement and contributed to the grudging respect with which even most of the OHA's critics regarded its work. The OHA was prepared to make difficult decisions at a time when even a wrong decision might be preferable to continuing uncertamty and inaction. Its willingness to do so was, at least in part, a function of its relative independence.

432. Possibilities include more frequent consultation, a greater willingness or capacity by the Department's political leaders to play a more active coordinating role, or a better system for clearing OHA decisions.

433. See supra notes $157-59$ and accompanying text. 


\section{The Problems of Equitable Criteria and Legitimacy.}

Occasionally, as in its Delta-Beacon standards, the OHA did manage to crystallize its decision criteria into rule-like form. The necessity for administering what amounted to a broad subsidy program demanded far more predictability and uniformity of treatment than did the typical OHA "hardship" exceptions. The latter tended to be highly fact-specific and idiosyncratic. But for the most part, the criteria that guided the OHA's broad equitable discretion remained scarcely more specific than the vague statutory criteria: "special hardship" "inequity," and "unfair distribution of burdens." As a result, the exceptions process successfully retamed the equitable character, situational orientation, and decisional flexibility for which it was origmally created. It did so, of course, at the risk of appearing to decide in an unpredictable and unprincipled manner. ${ }^{434}$

Agency decisions that confer valuable advantages upon one or a few firms vis-a-vis their competitors or the general public can easily be impugned as being motivated by the prospect of narrow partisan advantage, personal favoritism, or otherwise illegitimate reasons. An exceptions process that provides special relief from valid, binding rules with which other firms must comply at considerable cost, is especially open to such criticisms. The OHA, whose decisions often conferred enornous economic, competitive, and political benefits upon particular firms, regions, or sectors, was unusually sensitive to this problem. ${ }^{435}$

In these circumstances, the OHA's reputation for integrity and nonpohitical decisionmaking was a precious asset. If the views of many lawyers who practiced before the agency are a rehable guide, the DOE succeeded rather well in preserving its reputation. The OHA's director and staff earned and retained high marks for administrative competence, analytical rigor, scrupulous honesty, and independence. The merits of some OHA decisions were extremely controversial. Moreover, many of those interviewed complained of the agency's arrogant

434. In an earlier study of the Department of the Interior's adjudication of land claims, Professor Strauss identified a similar failure of the adjudicators to state their standards in the form of readily accessible rules, although the standards were susceptible to such codification. He suggested a number of procedural reforms to encourage the adjudicators to do so, including creating a separate office to state policy in rule form, or permitting outside parties to stimulate such codification. As Strauss pointed out, lowever, such reforms are unlikely as a practical matter to induce rulemaking that the agency wishes to avoid. See Strauss, supra note 70, at 1266-69.

435. The initial Ashland decision alone was worth over $\$ 50$ million to the company. The Ohio Independents decision was worth $\$ 14$ million, and might have affected President Carter's electoral strength in Ohio. Delta-Beacon relief, eventually amounting to $\$ 300$ million annually, protected some small refiners and their customers from extinction, and significantly dramed the valuable entitlements pool. See supra notes $192-93$ and accompanying text. 
personnel, informal decision procedures, and eagerness to press its powers to (or even beyond) valid limits. None, however, questioned the integrity or legitimacy of its decision process. By all accounts, the OHA decided cases on its view of the inerits, without regard to partisan or other inappropriate considerations.

The absence of vice, of course, is not quite the saine as the presence of virtue. The case for an exceptions process hike OHA's cannot rest upon inere scrupulousness. Nevertheless, the OHA's reputation for integrity and coinpetence is no trivial inatter. It represents a considerable administrative achievement in an era of widely perceived bureaucratic failure and in a regulatory prograin often denounced for both incompetence and susceptibility to narrow political pressures.

It is also important to recognize, however, that this achievement probably cannot be readily replicated. The OHA's structural separation, adjudicatory image, and relative independence may have facilitated its success, but they could not assure it. The energy lawyers who were interviewed seemed convinced that the OHA's legitimacy would have been in far greater jeopardy had someone less able and scrupulous than Melvin Goldstein been administering the exceptions process. This is both a crucial consideration and a troubling one. Any decision process whose integrity and public acceptability depend critically upon the idiosyncratic personality of the individual who happens to be running it at the time must give one cause for concern. Public officials like Goldstem, many observers emphasized, are in short supply in public agencies today - or in any day. The legitimacy of an exceptions process can neither be left to the character of its leadership nor be rendered immune from that influence. It inust instead be addressed institutionally, largely by ineans of adequate procedures and external controls.

\section{The Problem of Procedures.}

The earlier discussion of OHA procedures suggests that they are inadequate in certain respects. ${ }^{436}$ Each deflciency deserves detailed analysis before a particular remedy is selected, and most plausible remedies would probably slow the decisionınaking process to some extent. Consideration should be given to changes that would: assure timely notice to all interested parties; permit adequate but appropriately controlled discovery at an early stage of the case; regulate ex parte communications; limit hearsay testimony by lawyers, especially when testimony by einployees with direct knowledge of the facts is feasible; establish safeguards to minimize the risk that interim exceptions relief,

436. See supra notes $354-410$ and accompanying text. 
once granted, will become permanent de facto, if not de jure; assure effective administrative review of exceptions decisions; separate the exceptions function from the function of reviewing remedial and enforcement orders; and encourage participation by significantly affected but madequately represented groups.

Perhaps the most troubling and systematic of the OHA's procedural defects arose from a substantive commitment-its simultaneous pursuit of both regulatory equity and policy influence. The process of common law-type adjudication, while reasonably well suited to regulatory equity, was poorly adapted to broad pohcymaking. First, because the APA's adjudicatory safeguards did not apply to the OHA, ${ }^{437}$ this approach engendered numerous legal challenges by regulated firms. Although these challenges were largely unsuccessful, the adjudicatory forms that the OHA employed gave a certain plausibility to many of these complaints. In that sense, the OHA was hoist by its own petard. Having wrapped itself in the mantle of judicial detachment, the OHA exposed itself to claims that it should conduct itself like a court. Second, and probably more important, its adjudicatory procedure, even in the hybrid form that emerged, was incapable of creating the analytical, evidentiary, and pohtical bases necessary to sustain the broad policy development and implementation tasks that it all too eagerly assumed.

This is an inherently difficult problem, one that seeins endemic to any decisionmaker that takes on two such disparate administrative tasks and performs them simultaneously-indeed often in the same proceeding. It is especially difficult when circumstances and personalities render the most obvious solution-the distribution of these tasks to two administrative units with different procedures, regulatory responsibilities, and claims to legitimacy-impractical, if not impossible. When the exceptions office undertakes to make broad policy decisions through adjudication, the predictable result is that it will adopt a decision mode that falls between two procedural stools.

The OHA's compromise, developing policy through adjudicatory forms lacking the conventional adjudicatory safeguards, was vulnerable to several different types of criticisms. In Ashland, for example, the summary nature of the OHA's decision process raised serious questions about the fairness of the proceedings to those opposing rehef. 438 In addition, the need to reduce Ashland's relief substantially on three subsequent occasions suggests that the process yielded a hearing record madequate to support the complex policy judgonents that were re-

437. See supra notes $355-58$ and accompanying text.

438. These are questions that the reviewing court might well have resolved against the agency had it known that the "temporary" rehef would last two and one-half years. 
quired. Similarly, in Ohio Independents, the OHA's truncated hearing procedures led to a remedy whose lack of programmatic and political acceptability could be traced, im part, to the narrow focus of the adjudicatory forum in which it was devised. It is almost inconceivable that such a result would have emerged from a rulemaking proceeding, even one conducted under expedited procedures. In that event, the ERA's rule on ANS crude pricing apparently handled the problem.

Such unsatisfactory policy results should not be surprising. As was deinonstrated in Part $\mathrm{I}$, a regulatory agency is organized to function as an engine of policy im ways that a court is not. ${ }^{439}$ The same, however, cannot be said of the agency's specialized exceptions adjudicators. The OHA's procedures, although adapted in an effort to support its policymaking role, were still constramed and characterized by the narrow, adjudicatory format of its decision process. ${ }^{440}$

Indeed, with respect to the typicahty of cases, exceptions adjudication by an agency may be even more poorly suited to broad policy development than traditional common law adjudication by a court. ${ }^{441}$ Almost all cases that come before common law courts are those im which both parties claim that they want to be governed by the existing rules. In contrast, those that came to the OHA were, by definition, "exceptional"; they were cases im which the apphicant claimed that the existing rules were inadequate or unjust. When adjudicatory records emphasizing such unusual circumstances are the basis for broad policy decisions, those decisons are likely to reflect a somewhat distorted or inadequate view of the relevant social reahity.

If policymaking through exceptions adjudication is deeply probleinatic, it does not follow that informal rulemakmg is always superior. Many exceptions decisions may be located toward the center of the hardship/policy exceptions contimuum, where adjudicatory procedures may still exert a powerful attraction. Others may have an important pohicy dimension that becomes apparent only after the exceptions proceeding is well under way or even completed. In still others, pohicy development through adjudication rather than rulemaking may represent sound social process as well. ${ }^{442}$

439. See supra notes 63-67 and accompanying text.

440. See supra notes $409-10$ and accompanying text.

441. This point is developed in a May 1983 letter to the author from Professor Martin Shapiro. Of course, the typicality of cases that come before judges, especially in public law litigation in the federal courts, should not be exaggerated. See P. ScHuck, supra note 57, at 157-58.

442. See, e.g., Diver, supra note 43, at 399-400, 428-30; see also NLRB v. Wyman-Gordon Co., 394 U.S. 759, 770-74 (1969)(Black, Brennan, Marshall, J.J., concurring). 
The quest for a single solution to this problein is the administrative equivalent of the search for a philosopher's stone. It is doomed to failure. Indeed, even to portray the problein as a procedural one may be quite misleading; as suggested in Part I, the procedural difficulty may merely be epiphenomenal, symptomatic of a fundamentally imtractable or misguided substantive regulatory mission. ${ }^{443}$

Even accepting that possibility, however, the general outlines of a "second best" system for exceptions decisions emerge from the OHA's experience. ${ }^{444}$ First, Congress or the agencies should establish a richer array of procedural options, a set of alternative decision modes that mirror the diverse mixture of competing values presented by different kinds of exceptions decisions: fairness to individual firms and consumers, accuracy, speed of decision, pohicy sensitivity, the substantive imterests at stake, the kinds of issues to be resolved, the kinds of procedures originally employed to generate the rule from which rehef is sought, and political accountability, among others. The formal adjudication and informal rulemaking categories estabhshed by the APA are merely end points on a spectrum of procedural formahity. They do not begin to exhaust the possibilities for procedural hybrids, much less new species.

Energy regulation had to be conducted in a most extraordimary pohicy context. It consisted of extremely dynamic, heterogeneous, unpredictable, and interrelated markets and a sluggish political-administrative apparatus paralyzed by a nearly inupossible task, overwhelming complexity, and pohtical stalennate. This regulatory world had surprisingly hittle in common with the one in which the APA was enacted almost forty years ago, or even with those in which the Securities and Exchange Commission or National Labor Relations Board regulate today. Energy policy decisions had to be made and changed much faster than informal ruleinaking, as a practical matter, permitted. They also had to be made with a much broader base of imformation, expertise, political acceptance, and legitimacy than exceptions adjudications could mobilize even with the OHA's innovative procedures.

This kind of regulatory context, at least, seems to call for some new procedural variants. As informal rulemaking becomes increasingly encrusted with judicialized procedures and other extra-APA requirements in the name of "regulatory reform," 445 the importance of a relatively expeditious, flexible, and discretionary policymaking instrument such as that originally envisioned by section 553 of the APA be-

443. See supra note 96 and accompanying text.

444. See also P. Schuck, supra note 50, at 187-90.

445. See supra notes $86-89$ and accompanying text. 
comes that much greater. It might, for example, take the form of a more summary rulemaking proceeding leading to temporary rules that would automatically "sunset" after a limited period, thereby ensuring periodic policy review by the agency. Eunergency interim relief granted through such rules or in an exceptions proceeding should be conditioned upon creation of an escrow fund, interest obligation, expiration date, or other mechanisin to ensure that the status quo ante can be effectively restored in the event that the agency or reviewing court subsequently determines that sucl relief was erroneous.

If the agency provides more procedural alternatives to admimistrators, the decision to select among thein becoines correspondingly significant. Greater attention, therefore, should be devoted both to the criteria that should guide what nust inevitably be a discretionary choice of procedural nodes, 446 and to the need for flexible adaptation in the hight of new information. If after an essentially adjudicatory exceptions proceeding is commenced, for exaunple, it appears that signifcant policy issues are implicated, the exceptions office might be required to inform the rulemaking office promptly in order to give the primary policyınaking apparatus an opportunity to supplement or supplant the exceptions proceeding. 447 If, however, the exceptions office proceeds with the case, it should seek to broaden public participation in its adjudication, inviting public comments on all significant pohicy, factual, and remedial issues in the case and conducting the proceeding in inuch the same way that a rulemaker would. In that event, the exceptions tribunal might be augmented by nembers drawn from the agency's policymaking organs.

\section{E. The Problem of Accountability and Control.}

To a degree unusual in public agencies exercismg politically controversial and policy-significant power, the DOE exceptions process was autonomous. Neither the administrative review committee nor the departmental leadership was significantly involved in even the most important OHA decision, with the notable exception of the Ohio Independents case. The DOE's program offices seldon participated in OHA's proceedings, at least formally. White House clearance of OHA orders, including those carrying broad economic and political consequences, was rare. Congressional oversight of the exceptions process was virtually nonexistent; one committee hearing was held during the

446. For a discussion of these criteria, see Aman, supra note 6, at 293-322.

447. At least the office should be so encouraged because, in practice, the requirement is unlikely to be judicially enforceable. 
motor gasoline crisis, and that had no observable effect. OHA easily deflected pressure from individual members of Congress and circumvented Congress's few statutory directives concerning OHA procedures. The complexity and "emergency" nature of the OHA's exceptions decisions elicited from the courts an abject deference years after the regulatory program had been established and the initial crisis had passed.

The OHA's substantial freedom from external controls had many advantages for the DOE. For that reason, the department's political leaders not only tolerated this autonomy but encouraged it. This reflected both their confidence in Melvin Goldstein's decisions and their perception that a relatively independent OHA constituted a valuable safety valve for a variety of internal and external pressures that had accumulated around the regulatory program. In a different context, of course, stricter bureaucratic controls inight well have been iniposed.

To the extent that an agency's leaders wish to delegate such autonoiny to inferior officials, there is probably little that administrative law can or should do to inhibit that delegation, so long as their ultimate accountability to the politically responsible agency head is preserved. Similarly, there is no way to compel Congress to take greater interest than it chooses to in the decisions of a particular agency. It is probably futile to expect Congress to conduct continuous and effective oversight of an exceptions process, even one as far-reaching as the DOE's. Only the most visible and politically explosive breakdowns, such as the motor gasoline crisis, are likely to engage Congress's sustained attention. Judicial oversight of exceptions decisions is likewise problematic, especially im the context of a perceived programmatic emergency.

If an exceptions process like the OHA's is to be subject to ineaningful external checks, if its performance is not to depend excessively upon the unusual talents of one individual, more systematic controls must be devised. These controls should safeguard the full range of values that the exceptions process is supposed to pursue. One possible reform is to encourage greater formal involvement by officials responsible for policy formulation and implementation. The Secretary, for example, could be required to sign off on exceptions decisions that meet certam criteria of significance. Obviously, such a requirement could be routinized and rendered pro forma, thereby defeating its purpose. Even if that occurred, however, accountability for policy decisions would be focused where it belongs. Alternatively, the agency's program offices could be given a formal, party-like role in the adjudicatory proceeding itself, through which they could apprise the exceptions office and the Secretary of important policy differences at a stage in the process early 
enough to influence the outcome. Reviewing courts, for their part, could take a more skeptical attitude toward "emergency" justifications for otherwise objectionable administrative procedures, especially as the regulatory program matures. 